\title{
DETERMINAÇÃO DO COEFICIENTE DE VARIAÇÃO DE GOTEJADORES E SUA INFLUENCIA NA UNIFORMIDADE DE EMISSÃO EM LINHAS LATERAIS DE IRRIGAÇÃO POR GOTEJAMENTO
}

\author{
ODAIR MORAES
}

Orientador: Prof. Dr. ANTONIO F. L. OLITTA

Dissertação apresentada à Escola Superior de Agricultura "Luiz de Queiroz", da Universidade de São Paulo, para obtenção do título de Mestre em Irrigação e Drenagem.

PIR A CICABA

Estado de São Paulo - Brasil Junho - 1984 


\author{
Aos meus pais, \\ Odilon e Martha C. Moraes, \\ pelo incentivo e compreensao, \\ DEDICO .
}

Se nao houver frutos, valeu a beleza das flores.

Se não houver flores, valeu a sombra das folhas. Se não houver folhas, valeu a intenção da semente.

(HENFIL) . 


\section{AGRADEC IMENTOS}

Ao Professor Dr. Antonio F.L. O1itta, do Depto de Enge nharia Rural da Escola Superior de Agricultura "Luiz de Queiroz" - USP, pela orientação e amizade demons tradas durante a realização deste trabalho.

Ao Prof. Dr. Wilson Ourives e Enga Yvone de Faria Lemos, do Centro Tecnológico de Hidrāulica (CTH), . da Universidade de São Paulo, e DAEE, pelas sugestões feitas para montagem do experimento.

Aos Profs. Dr. Humberto de Campos e Dr. Décio Barbin, do Deptọ de Matemática e Estatística da Escola Superior de Agricultura "Luiz de Queiroz" - USP, pelas recomendações na anālise estatística dos dados.

Ao Depto de Engenharia Rural da Escola Superior de Agri cultura "Luiz de Queiroz" - USP, pela cessão do Laboratōrio de Hidráulica para a realização da pesqui sa.

Ao Engo-Agro Carlos Alberto Barth Freitas, da firma DANTAS - Indústria e Comērcio S.A., pela cölaboração no envio do material necessário ao estudo.

Ao Eng?-Agro Carlos Vieira Pinheiro Neto, da firma IRTEC - Tecnologia de Irrigação Ltda., pela colaboração no envio do material necessário ao estudo. 
A Fundação de Amparo à Pesquisa do Estado de São Pau10 (FAPESP), por ter concedido bolsa de estudos para o desenvolvimento da pesquisa.

A Profa Marly Moreira Dias, do Centro de Processamento de Dados da Fundação de Ensino e Tecnologia de Alfenas - FETA, pela colaboração na elabọação do pro grama de computador utilizado neste trabalho.

Aos funcionários do Laboratório de Hidráulica do Deptọ de Engenharia Rural da Escola Superior de Agricultu ra "Luiz de Queiroz" - USP, pela colaboração na mon tagem da banca de testes.

Aos colegas do curso de pós-graduação em "Irrigação e Dre nagem", pelo apoio e amizade demonstrados durante a realização do curso.

E a todos aqueles que de alguma maneira nos deram inspi ração e forças para a conclusão deste trabalho.

OFEREÇ . 
Pảg.

RESUMO

viii

SUMMARY

xi

1. INTRODUCGAO 1

2. REVISATO DA LITERATURA

2.1 - Hidráulica de Sistemas de Irrigação por Go tejo ...................... 9

2.2 - Uniformidade de Aplicação ......... 14

2.2.1 - Fatores que afetam a uniformidade de emissão $\ldots \ldots \ldots \ldots \ldots \ldots \ldots 17$

2.2.2 - Estimativa da uniformidade de emis são $\ldots \ldots \ldots \ldots \ldots \ldots \ldots \ldots \ldots \ldots \ldots \ldots \ldots$

2.2.3 - Coeficiente de uniformidade de ir

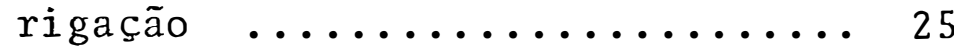

2.3 - Dispositivos de Emissão (Gotejadores) ... 29

2.3.1 - Variação na fabricação dos gotejadores................... 32

2.3.2 - Coeficiente de variação de fabricação do gotejador $\ldots \ldots \ldots \ldots \ldots 35$

2.4 - Relacionamento entre Pressão e Taxa de F1uxo do Gotejador ............. 40

3. MATERIAL E MÉTODOS $\ldots \ldots \ldots \ldots \ldots \ldots \ldots \ldots \ldots$

3.1 - Descrição do Laboratório de Hidráulica .. 45

3.2 - Descrição dos Gotejadores ......... 45 
3.3 - Descrição do Sistema .............. 49

3.4 - Descrição dos Testes com os Gotejadores 53

3.4.1 - Determinação da uniformidade de vazão dos gotejadores $\ldots \ldots \ldots$.... 56

3.4.2 - Determinação da equação característica de vazão-pressão dos gotejadores $\ldots \ldots \ldots \ldots \ldots \ldots \ldots 62$

3.5 - Distribuição de Vazão dos Gotejadores .. 64

3.6 - Uniformidade de Aplicação dos Gotejadores 67

3.6.1 - Uniformidade de Emissão dos gote jadores na linha lateral ..... 67

3.6.2 - Coeficiente de Uniformidade na linha lateral ............ 74

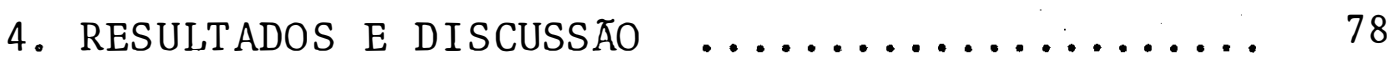

4.1 - Uniformidade de Vazão dos Gotejadores .. 78

4.1 .1 - Gotejador IRTEC-1 .......... 79

4.1 .2 - Gotejador IRTEC-2 $\ldots \ldots \ldots \ldots .84$

4.1 .3 - Gotejador DANTAS ......... 87

4.1 .4 - Resultado global $\ldots \ldots \ldots \ldots \ldots 90$

4.2 - Distribuição de Vazão dos Gotejadores .. 94

4.3 - Equação Característica de Vazão-Pressão do Gotejador ................. 99

4.3 .1 - Análise da variância ........ 100

4.3 .2 - Equação geométrica .......... 103 
vii.

Pāg.

4.3 .3 - Regressão polinomial ....... 113

4.3.4 - Anāilise final ........... 122

4.4 - Unifórmidade de Aplicação dos Gotejadores 128

4.4.1 - Uniformidade de Emissão dos gotejadores na linha latera $1 \ldots \ldots 128$

4.4.2 - Coeficiente de Uniformidade na $1 \underline{i}$ nha lateral ............... 143

5. CONCLUSOES $\quad \ldots \ldots \ldots \ldots \ldots \ldots \ldots \ldots \ldots \ldots \ldots \ldots$

6. Literatura Citada $\ldots \ldots \ldots \ldots \ldots \ldots \ldots \ldots \ldots \ldots$

APENDICE 1 - Dados obtidos nos testes de Uniformidade de Vazão ................... 162

APENDICE 2 - Resultados gerais dos testes de Uniformidade de Vazão ............ 172

APENDICE 3 - Dados obtidos nos testes para Determi nação da Equação Característica de Des carga-pressão $\ldots \ldots \ldots \ldots \ldots \ldots \ldots 182$

APENDICE 4 - Resultados da análise de regressão pa ra as equações geométrica e polinomial 
DETERMINAÇAO DO COEFICI ENTE DE VARIAÇAO DE GOTEJA DORES E SUA INFLUENCIA NA UNIFORMIDADE DE EMISSĀO

EM LINHAS LATERAIS DE IRRIGACAOO POR GOTEJAMENTO

Autor: Odair Moraes

Orientador: Prof. Dr. Antonio F.L. Olitta

O objetivo deste trabalho foi o de verificar a uniformidade de emissão de água em três tipos - de gotejadores produzidos no Brasil .

Para tail, realizaram-se testes, no Laboratório de Hidräulica da ESALQ/USP, para estimar a variação na vazão dos gotejadores, causada pelas diferenças decorrentes do processo de fabricação, determinando-se, assim, o Coeficiente de Variação de Fabricação $\left(\mathrm{CV}_{f}\right)$, bem como a influência na distribuição de taxas de emissão e o seu efeito na uniformidade de aplicação de água em linhas laterais. Também, procurou-se estabelecer as equações características de descarga-pressão pa ra os gotejadores testados. 
As repetições realizadas no Teste de Uni formidade mostraram que o Coeficiente de Variação de Fa bricação pode diferir entre as amostras testadas, embora estes valores tenham se definido dentro de : intervalos específicos para cada modelo de gotejador experimen tado.

Com a reunião dos valores de vazão das três amostras de cada modelo de gotejador, 'determinou-se o Coeficiente de Variação de Fabricação global $\left(\mathrm{CV}_{f g}\right)$, revelando um valor bem menor para o gotejador DANTAS $(5,17 \%)$, em comparação com o microgotejador IRTEC $(14,03 \%)$ e o gotejador IRTEC $(17,70 \%)$.

As tabelas de Uniformidade de Emissão re velaram que uma Uniformidade de Emissão de $90 \%$, em trēs níveis de pressão de serviço a serem adotados, não será atingida para o gotejador IRTEC até com quatro gotejado res por planta, com qualquer valor da razão de perda de carga: Para o microgotejador IRTEC somente será atingida com a utilização de quatro gotejadores por planta. E para o gotejador DANTAS poderá ser atingida com a adoção de valores mais altos para a razão de perda de carga, com o aumento do número de gotejadores por planta.

Com relação ao Coeficiente de Uniformida de na linha lateral de irrigação, tanto para o goteja- 
dor IRTEC, como para o microgotejador IRTEC, haverá necessidade de colocar-se dois gotejadores ou mais por planta, para que um coeficiente acima de $90 \%$ seja alcan çado, enquanto que, para o gotejador DANTAS, mesmo com 1 (um) gotejador por planta, este coeficiente será cerca de $96 \%$.

Tambēm, o Tempo Corrigido de Irrigąço será relativamente maior se o Coeficiente de Variação de Fabricação do gotejador for elevado, para que uma de terminada porcentagem de plantas fosse esperada estar adequadamente irrigada. 
DETERMINATION OF THE COEFFICIENT OF MANUFACTURING VARIATION OF EMITIERS AND ITS INFLUENCE ON THE EMISSION

UNIFORMITY OF DRIP IRRIGATION LATERAL LINES

Author: Odair Moraes

Adviser: $\quad$ Prof. Dr. Antonio F.L. O1itta

The purpose of the present work was to check the uniformity with which the water flow rate is - dircharged from three different types of emission devices manufactured in Brazil.

To this end, tests were carried out at the Hydraulics Laboratory of the Rural Engineering Department - ESALQ/USP, to estimate the variation in the flow of trickle emitters, caused by the differences resulting from the manufacturing process, thus determining the Coefficient of Manufacturing Variation $\left(\mathrm{CV}_{f}\right)$, as well as the influence on the distribution of flow rates and its effect on the water application uniformity of lateral lines. It was also tried to establish the discharge- 
xii.

-pressure characteristic equations for the emitters being tested.

The replications of the Flow Uniformity Test indicated that the Coefficient of Manufacturing Variation $\left(\mathrm{CV}_{f}\right)$ may be different for the samples tested, though these values were clearly defined within especific intervals for each emitter type experimented. With the flow values for the 3 samples of each emitter, a global Coefficient of Manufacturing Variation $\left(\mathrm{CV}_{f g}\right)$ was determined, showing quite a lower value for the DANTAS emitter $(5,17 \%)$ as compared to the IRTEC microemitter $(14,03 \%)$ and the IRTEC emitter $(17,70 \%)$.

The Emission Uniformity tables showed that an Emission Uniformity of $90 \%$, at the 3 levels of pressure head to be adopted, will not be attained for the IRTEC emitter even with 4 emitters per plant, with any value of head loss ratio. For the IRTEC microemitter it will only be attained by utilizing 4 emitters per plant. And for the DANTAS emitter it can be attained by adopting higher values for the head loss ratio, with an increase in the number of emitters per plant.

Regarding the Uniformity Coefficient for the irrigation lateral line, for the IRTEC emitter and the IRTEC microemitter as well, two or more emitters per plant will be required to attain a coefficient above 
$90 \%$, while for the DANTAS emitter, even with only one emitter per plant this coefficient will be around $96 \%$. Also, the Corrected Time of Irrigation will be relatively longer, with a high Coefficient of Manufacturing Variation of the emitter, for a determined percentage of plants to be adequately irrigated. 


\section{INTRODUCGATO}

O-sistema de irrigação por gotejamento é um método de aplicação de āgua às plantas, que foi introduzido no Brasil, efetivamente, a cerca de 10 anos, com tecnologia de países mais desenvolvidos neste setor, nos quais tornou-se bastante difundido devido aos benefícios proporcionados por este método, tais como:

- (1) sensíveis aumentos na produtividade de várias culturas, em decorrência de um melhor controle da umida de do solo ao redor das plantas, permitindo flutuações mínimas no seu teor durante o ciclo de irrigação;

(2) grande economia no uso d'água, pois a eficiência da irrigação é das mais altas, em relação aos outros métodos, redundando num melhor aproveitamento dos 
recursos hídricos em regiões onde há escassez de água.

0 gotejamento, como método de irrigação, foi inicialmente desenvolvido em Israel, onde utilizou-se canalizações de aço perfuradas uniformemente e com o advento do material plástico, mais econômico e pro porcionando uma maior flexibilidade ao sistema, impulsionou grandemente as pesquisas nesta ärea; com o aparecimento dos primeiros gotejadores especialmente idea lizados para este fim, no início da década de 60 (GUSTAF SON, 1971).

A difusão deste método ocorreu em inúmeros outros países, como nos Estados Unidos, Austrâa 1ia, Inglaterra, França, Itália, Alemanha, África do Sul, México, Espanha e Japão.

Atualmente a irrigação : por 'gotejamento tem se desenvolvido bastante, pois existe uma preocupa ção, por parte das firmas que comercializam este sistema de irrigação, no aperfeiçoamento de seus equipamentos e dispositivos de emissão, bem como em pesquisar no, vas tecnologias, sempre tendo por finalidade: facilitar a operação e manejo do sistema para os agricultores; proporcionar melhor uniformidade de distribuição de água pelos dispositivos de emissão (gotejadores) e fazer com que haja uma redução no preço de aquisição do sisistema, 
permitindo, assim, a sua utilização por um maior número de agricultores.

Em 1976, Gustafson (apud OLIVEIRA, 197.8

e FARIA, 1981) apresentou levantamento da área irrigada (em hectares) por gotejamento, realizado em diversos países, e fez a previsão, para o ano de 1980, de cerca de 350.000 ha irrigados por este método, no mundo, e pa ra o Brasil cerca de 6.000 ha.

Segundo consulta aos fabricantes que comercializam este" tipo de sistema de irrigação, estima-se que, até o ano de 1982, já haviam sido instalados no Brasil cerca de 2.400 ha, prevendo-se uma expansão maior para os próximos anos devido ao incentivo proporcionado pelo Programa de Financiamento para Aquisição de Equipa mentos de Irrigação (PROFIR), do Ministério dá Agricultura.

Para que um sistema de irrigação por gotejamento funcione adequadamente, dentro do limite de variação aceitáve1, hã necessidade de um rigoroso controle na pressão e vazão dentro do sistema. Existem crị térios rígidos de dimensionamento hidráulico do sistema, e tambëm a necessidade de alguns componentes do sistema trabalharem com uma pressão superior à de serviço do go tejador. O relacionamento entre a pressão e a vazão dependerá das características hidrâulicas de fluxo nos go 
tejadores e da pressão de operação do sistema (OLITTA, 1977).

o ideal seria que a aplicação da água por todo o sistema de irrigação por gotejo fosse absolutamente uniforme. Para gotejadores espaçados uniformemente, isto exigiria que cada gotejador tivesse a mesma ta xa de descarga, embora diferenças de pressão sejam inevitáveis ao 1ongo da linha 1 ateral.

$\mathrm{Na}$ prática as taxas de descarga dos gote jadores variam consideravelmente devido a diversos fato res, tais como:

(1) características do gotejador projetado;

(2) variabilidade na sua fabricação;

(3) tempo de uso dos gotejadores;

(4) perdas de carga por atrito nas tubulações da rede de distribuição;

(5) diferenças topográficas na área do projeto;

(6) o número de gotejadores entupidos no sistema;

(7) o número e o grau de gotejadores parcialmente entupidos no sistema;

(8) variação na temperatura da água por todo o sis tema.

Os efeitos de cada um dos fatores citados acima, na uniformidade de aplicação da água, podem ser 
variáveis, contudo a variabilidade na fabricação dos go tejadores pode ser particularmente importante.

No dimensionamento de sistemas de irriga ção por gotejo usa-se apenas as diferenças de nível do terreno e as perdas de carga ocorridas por atrito ao longo do tubo de polietileno, para determinar-se o comprimento da linha lateral de irrigação, de acordo com a vazão nominal do gotejador a uma determinada pressão de serviço. Porêm, em trabalhos mais recentes, tem-se dado relevância à variabilidade existente de gotejador para gotejador, decorrentes de sua fabricação, devido a suas reduzidas'dimensões.

Deve-se salientar que ê praticamente impossível fabricar qualquer de duas unidades exatamente iguais. Alguma variação sempre existirá entre objetos su postamente "idênticos". A situação na irrigação por gotejo ê tal que essas diferenças de gotejador para gotejador não são desprezíveis, podendo afetar :enormemente a uniformidade de aplicação de água às plantas.

0 dispositivo de emissão do sistema de $\underline{i} \underline{r}$ rigação por gotejamento é projetado para liberar a água a uma taxa de fluxo muito baixa. Por isso, as dimensões críticas do dispositivo tendem a ser pequenas e difíceis para fabricar precisamente. As variações que possamocor 
rer, embora pequenas em magnitude absoluta, podem repre sentar uma relativamente grande variação porcentual.

Assim é que, se dois gotejadores tirados de um mesmo lote forem testados na mesma pressão e temperatura, poderão ter diferentes vazões. O total da diferença a ser esperada variará de um modelo de gotejador para outro, dependendo do projeto do gotejador, dos materiais usados em sua construção e do controle de qua lidade com o qual é fabricado.

Portanto, este trabalho de dissertação tem por objetivo verificar a uniformidade de emissão de àgua em três tipos de gotejadores produzidos no Brasil, pretendendo-se estabelecer as Equações Caracteristicas de Descarga-Pressão para cada modelo de gotejador estudado, e observar a variação na vazão dos gotejadores, causadas pelas diferenças entre eles, decorrentes do pro cesso de fabricação, determinando-se o Coeficiente de Variação de Fabricaçao dos gotejadores $\left(\mathrm{CV}_{f}\right)$, a sua influência na distribuição de taxas de emissão (vazão) ob. tidas através de testes realizados com amostras de gote jadores, e o seu efeito na uniformidade de aplicação de àgua em linhas laterais de irrigação por gotejo a serem dimensionadas. 
7.

\section{REVISÃO DA LITERATURA}

A introdução do método de irrigação por gotejamento não deve ser considerada somente como uma nova técnica para suprir água às culturas, mas, sim, co mo uma nova filosofia em termos de aplicação de ägua, fazendo parte integrante de um conjunto dé técnícas agrí colas nos cultivos de determinadas plantas, sob condições controladas de umidade do solo, adubação, salinida de, fitossanidade e variedades selecionadas, de modo que se obtenham efeitos significativos na produção por área e por água consumida, bem como na época da colheita e na qualidade do produto (BERNARDO, 1982).

A potencialidade do uso da irrigação por gotejamento na condução das culturas foi evidenciada por GOLDBERG e SHMUELI (1970), em experimentos realizados 
com as culturas de pepino, tomate, melão e uva, traba1hando-se em condições de clima ärido, ;sölo ;isalino e água contendo alto teor de sais, onde obteve-se resulta dos favoráveis. Também, vários outros pesquisadores, de diferentes países, durante o 2 ? Congresso Intèrnaciónal de Irrigação por Gotejamento, realizado em San Diego, Califórnia, em 1974, ressaltaram esses resultados, apre sentando trabalhos que evidenciaram o efeito do gotejamento em diversas culturas, proporcionando respostas al tamente satisfatōrias.

Em virtude destes resultados obtidos,com relação ao aumento da produtividade de diversas culturas, sob determinadas condições e situações, e a outros fatores que contribuïram para a rápida aceitação no uso desse método de irrigação, deparou-se com uma relativa escassez de informações sobre esse assunto, tendo surgi do diversas dúvidas, desde a escolha do tipo de gotejador. a ser empregado até a elaboração de um projeto hidráulico do sistema de irrigação por gotejamento.

De acordo com HANSON (1973), a literatura existente sobre este assunto, até o ano de 1973 , à exceção de poucos trabalhos publicados, encontrava-se disponível apenas na forma de panfletos ou manuais fornecidos por firmas fabricantes de equipamentos para es- 
te tipo de irrigação.

De posse desses, até então, limitados co nhecimentos existentes, KELLER e KARMELI (1974a) apresentaram um trabalho com informações necessárias ao dimensionamento de um sistema de irrigação por gotejamento.

2.1 - Hidräulica de Sistemas de Irrigação por Gotejo

O. projeto de um sistema de irrigação por gotejamento deve ser planejado como um todo, de modo a fornecer a quantidade necessária de água às plantas, se gundo o esquema de irrigação projetado. Contudo, estes sistemas não aplicam a água com uma uniformidade perfeita ao longo da linha de plantas.

Esta não uniformidade é causada, entre outros fatores, pelas imperfeições na fabricação dos go tejadores e pelo entupimento que poderá ocorrer durante o tempo de uso dos mesmos. Esses problemas podem ser cor rigidos pelo aperfeiçoamento dos processos de fabricação e pela filtragem da água para remoção de partículas grosseiras em suspensão e de matéria orgânica contidas na água de irrigação, além de técnicas de controle (manejo) para evitar precipitação de sal, quando for usada água com altos teores de sais. 
0 maior problema, do ponto de vista de projeto do sistema, é a fricção (atrito) causada pela resistência oferecida ao escoamento do fluxo de :água, sob pressão, pelas paredes internas da linha lateral. A menos que o sistema seja projetado para compensar esta variação de pressão, a vazão do gotejador variaráa ao lon go da linha la.teral.

Vârios fabricantes têm projetado gotejadores para reduzir variações de vazão causadas pelas mu danças de pressão, ocasionadas pelo atrito na linha 1a teral.

Algumas maneiras foram então introduzidas, como:

- gotejadores auto-regulâveis, onde seria ajustada uma determinada vazão para todos os : gotejadores ao longo da linha lateral;

- laterais de tubos de parede dupla com orificios espaçados uniformemente ao longo da linha;

- gotejadores de alta perda de carga, consistindo de longos canais espirais de diâmetro pequeno, em um arranjo rosca-parafuso, e também através de labirintos, descarregando de linhas laterais ope radas a pressões maiores $(1,0$ atm.). 
Para este último tipo de gotejador citado, a maior parte da perda de carga no sistema ocorrerá nos gotejadores, de modo que o efeito de mudanças de pressão ao longo da linha lateral è relativamente peque no. Boa uniformidade de aplicação é possível com este sistema. As desvantagens incluem maior susceptibilidade de entupimento do gotejador, custos mais elevados do go tejador e o custo de manter uma pressão maior no sistema.

Devido à variação de descarga na linha lateral, a linha de gradiente de energia não será uma linha reta, mas uma curva do tipo exponencial. A distri buição de pressão ao longo da linha lateral poderâ ser obtida apenas se a linha de gradiente de energia é conhecida.

MEYERS e BUCKS (1972) propuseram uma solu 'ção gräfica usando um sistema calibrado com gotejador mültiplo, para obter descarga uniforme do gotejador, en quanto KENWORTHY e KESNER (1974) propuseram regular o comprimento de um gotejador, tipo microtubo, com o fim de obter descarga uniforme de cada gotejador. Os resultados destas pesquisas têm mostrado que a descarga uniforme pode ser alcançada se a distribuição ao longo da linha puder ser determinada. 
WU e GITLIN (1973) desenvolveram um sim ples modo de estimar a distribuição de pressão ao longo de uma linha de gotejadores e apresentaram vários meios para regular ou adaptar gotejadores com a finalidade de alcançar uma descarga uniforme do gotejador, como desejado. Notaram, também, que o dimensionamento de curvas de pressão para linhas de gotejadores, calculadas por repetidas vezes, tinham a mesma forma.

KELLER e KARMELI (1974b), além disso, in dicaram que a forma geral e características da curva de perda de carga da linha lateral de gotejadores são essencialmente independentes do expoente de descarga " $x$ " do gotejador e do total da perda de carga.

Em geral, a taxa de fluxo através do gotejador é controlada pela carga hidráulica atuando no gotejador e pelas dimensões da passagem de fluxo do gotejador. Desde que a água esteja fluindo através da 1inha lateral, ocorrerā una perda de energia devido ao atrito e uma distribuição de pressão existirā ao longo do comprimento do tubo. Se a geometria do gotejador é fixada, então uma distribuição da taxa de fluxo correspondente, proporcional à distribuição de pressão, existirá ao longo do comprimento do tubo. 
Conforme os trabalhos apresentados por KENWORTHY (1972), MEYERS e BUCKS (1972), BUCKS e MEYERS (1973) e WU e GITLIN (1973), foram desenvolvidos procedi mentos para projeto da linha lateral de gotejo que espe cificavam o uso de gotejadores de tamanhos diferentes (diâmetro do orifício ou tamanho do microtubo) por todo o sistema, para alcançar-se melhor uniformidade. Contudo, em geral, na prática as características do gotejador" são comumente fixadas e a taxa de fluxo é determina da unicamente pela pressão, alèm do que a utilização de gotejadores de calibres diferentes em um sistema, exigㅌ ria construção, instalação no campo e práticas de manutenção, que são geralmente consideradas impraticâveis pa ra uso a nível de campo.

HOWELL e HILER. (1974) deduziram equações, a serem utilizadas em projetos do sistema, para determinar comprimentos de linhas laterais em irrigação por gotejamento para uma uniformidade de fluxo selecionada. As equações de projeto são desenvolvidas de princípios da mecânica dos fluidos e são dependentes das ca racterísticas hidráulicas do gotejador e da linha lateral. Em outros trabalhos, HOWELL e HILER (1974a e 1974b), discutiram o método em detalhes e proporcionaram soluções gräficas. 


\section{2 - Uniformidade de Aplicação}

Segundo SOLOMON (1976), vârios dispositị vos de emissão (gotejadores), substituições de material usado em sua construção e técnicas de projeto são dispọ niveis para minimizar os problemas que levam para a desuniformidade de aplicação, mas todos eles custam dinheiro e/ou tempo. Assim, os custos de aproximar-se da perfeição deveriam ser pesados cuidadosamente contra os custos de não a1cançá-1a.

Perda de potencial de produção e desperdícios de recursos de irrigação são também consequências indesejâveis de uma falta de uniformidade de emissão •

Ainda uma outra razão para ser considera da com a uniformidade de aplicação, é que ela desempenha um importante papel no processo de programação dá ix rigação. Programação cuidadosa e, tempo e total de irrigação, podem ter considerável valor em termos de eco-

nomia de água e melhoria de produção por unidade de ārea e/ou produção por unidade de água. A programação da irrigação é basicamente um processo para manter-sesob con trole io estado de umidade do solo na zona do sistema ra dicular. 
Os totais de água acrescidos à zona radi cular pela irrigação ou precipitação e os totais de água removidos da zona radicular pela evapotranspiração, atê o momento, são baseados em estimativas. E necessärio co nhecer-se a eficiência do sistema de irrigação, tal que - relacionamento entre totais brutos de irrigação e adi ções líquidas à zona radicular possa ser estabelecido.

A eficiência de sistemas de irrigação por gotejo depende diretamente da uniformidade com a qual a ăgua é descarregäda dos dispositivos de emissão por todo o sistema.

WU e GITLIN (1973), HOWELL e HILER (1974) e GOLDBERG et alii (1976), ressaltam que os maiores fatores que afetam a uniformidade das taxas de fluxodos dispositivos de emissão são, comumente, atribuidos às características do gotejador projetado e às diferenças de pressão no sistema, devido a perdas de energia por atrito e a diferenças de elevação do terreno.

HOWELL e'HILER (1974) apresentaram um pro cedimento para dimensionamento de uma linha lateral de gotejamento baseado no Coeficiente de Uniformidade (CU), no qual os efeitos na uniformidade de aplicação, das ca racterísticas do gotejador projetado, das perdas de car ga por atrito por toda a tubulação da rede de distri- 
buição e das diferenças de elevação por todo o campo, são levadas em consideração.

Contudo, a variabilidade na fabricação e tempo de uso dos gotejadores podem ser muito importantes. Além disso, a distribuição dos valores observados devido às variações de pressão não é dada sempre pela distribuição de Gaussian.

KELLER e KARMELI $(1974 \mathrm{a}, \mathrm{b})$, SOLOMON (1976 e 1977) e SOLOMON e KELLER (1978), apontaram para este fator, o qual deveria ser considerado, que é a variação unidade/unidade com a qual os dispositivos de emissão são fabricados. Esta variação na fabricação de gote jadores pode também ter uma maior influência na uniformidade de sistemas de irrigação por gotejo, e não deveria ser deixada de lado.

Jä SOLOMON e KELLER (1978) , consideraram os efeitos na uniformidade de aplicação, das caracterís ticas do gotejador projetado, da variabilidade na fabri cação e tempo de uso dos gotejadores, e das perdas de carga por atrito por toda a tubulação da rede de distribuição, assumindo a temperatura da água constante e que nenhum gotejador sofria de qualquer grau de entupimento. Não há nenhum método analítico prático para lidar com todos os oito ítens, relacionados anteriormente, 
responsáveis pela variação nas taxas de fluxo dos gotejadores, durante o projeto do sistema. Contudo, um procedimento de campo para avaliar a uniformidade de um sis tema em operação é apresentado por KELJER' e KARMELI'(1974a, b) e por MERRIAN et alii (1975).

o estudo da uniformidade de aplicação na irrigaçäo por gotejo é chamadà "Uniformidade de Emis.. são", e pode referir-se ou a uniformidade de totais em $\underline{i}$ tidos ou a taxas de emissão. A Uniformidade de Emissão é importante, porque é um dos dois componentes da Eficiência de Irrigação (o outro sendo várias perdas associadas com o sistema de irrigação).

Um projeto considerável do sistema e o eșforço no manejo da irrigação são direcionados para ir de encontro com o problema de falta de uniformidade na aplicação de água, através do método de irrigação por gotej amento .

\subsection{1 - Fatores que afetam a uniformidade de emissão}

Desde taxas de emissão, que são a primei ra consideração na Uniformidade de Emissão, qualquer coị sa que afete uma taxa de descarga do gotejador pode afe tar a uniformidade de emissão de um sistema de irrigação por gotejo. 
Os fatores que afetam a uniformidade de emissão de um sistema de irrigação por gotejamento são citados por SOLOMON (1976):

Primeiro: o próprio gotejador influencia a taxa de emissão. Características da passagem de fluxo no goteja dor, projetado e fabricado, são importantes em determi nar como a taxa de emissão responde para as outras variâveis que estão influindo.

Segundo: hä alguma variabilidade na fabricação de gotejadores. Nenhum processo de fabricação é tão exato que produz unidades iguais tempo após tempo. Portanto, mesmo sob condições idênticas, taxas de emissão podem variar de um gotejador para o próximo.

Terceiro: perdas de energia por atrito por toda a rede de distribuição afetam taxas de emissão. Perdas por atrito causam a variação da pressão disponível em cada gotejador locajizado. Em geral a taxa de emissão ë uma função dả pressão disponível.

Quarto: diferenças de elevação por toda a' parcela do sistema de gotejo afetam as taxas de emissão. Topografia irregular também causa variações de pressão dentro do sistema.

Quinto: o número de gotejadores entupidos no siste 
. ma é uma consideração óbvia. Os caminhos críticos da pas sagem do fluxo nos gotejadores são muito pequenos, tal que sem filtragem suficiente da água de irrigação, resultará em entupimento inevitável. Um bom sistema de fil tragem, apropriado para as exigências do gotejador utilizado, e com uma manutenção e manejo adequados, minimi zaria este fator.

Sexto: o número e grau de gotejadores parcialmente entupidos afeta a uniformidade de emissão. Mesmo com bons sistemas de"filtragem, alguns gotejadores sofrerão este problema. Se hã partículas finas de silte e argila na āgua, elas poderiam depositar-se nas passagens de flu xo do gotejador, pois as velocidades d'água nestas āreas são baixas. Isto ligeiramente reduz o diânetro de passa gem, causando um decréscimo gradual na taxa de emissão. Sêtimo: a temperatura da água nas linhas plásticas podem influenciar as taxas de emissão. Se as linhas são colocadas na superfície do terreno, e estão sujeitas ao calor solar, a temperatura da água variará dependendo da hora do dia ou da noite, e outras condições atmośfëricas. A taxa de emissão de alguns gotejadores depende da viscosidade da água, a qual por sua vez depende da temperatura da água. A temperatura da água pode influenciar as taxas de emissão de alguns gotejadores, porque afeta 
as dimensões ou características de certas partes críti cas no interior dos gotejadores.

Oitavo: em alguns casos, a idade dos gotejado res afeta a taxa de emissão. Um gotejador que .está no campo por algum tempo pode sofrer algum grau de entupimento parcial. Em outras circunstâncias, o envelhecimen to pode ter alterado as características de algumas partes do gotejador.

2.2.2 -.. Estimativa da uniformidade de emissão

Em irrigação por gotejo, a tendência é de aplicar-se totais reduzidos de ägua para a planta, alèm de irrigar-se somente uma porção da zona radicular das piantas.

Em razão disto, KELLER e KARMELI (1974) usaram a relação entre as menores taxas de emissão com a taxa de emissão média, que ocorreria dentro do sistema, para estimar-se a uniformidade de emissão de um determinado projeto do sistema de irrigação por gotejo.

Este processo considera as taxas de emis são abaixo da mêdia como mais importantes, do que aquelas acima, e tambêm considera as mais baixas taxas de emissão como sendo mais importantes do que aquelas somente um pouco abaixo da média. 
Os autores notaram que este relacionamen to é o mais importante fator na uniformidade de aplicação, desde que um dos objetivos originais de um projeto do sistema de irrigação por gotejo é o de assegurar capacidade suficiente ao sistema para irrigar adequadamen te a área que receber menor quantidade de água, parece razoável preocupar-se mais com a falta do que com o excesso de água aplicado em cada planta.

Estes autores sugeriram dois parâmetros para definir a uniformidade de aplicação de um sistema de irrigação por gotejo: a Uniformidade de Emissão do Projeto (UE) e a Uniformidade de Emissão no Campo (UE'), que são, provavelmente, mais relevantes para a irrigaçäo por gotejamento do que o Coeficiente de Uniformida.de (CU) usado na irrigação por aspersão.

Para estimar a Uniformidade de Emissão (UE) para um determinado projeto, propuseram a seguinte fórmula:

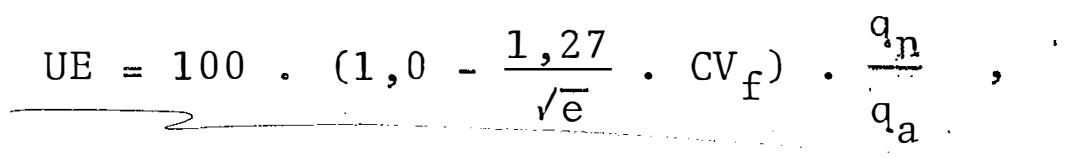

em que:

UE é a uniformidade de emissão do projeto, em porcentagem;

$\mathrm{CV}_{f}$ é o coeficiente de variação de fabricação pa ra o gotejador utilizado, adimensional; 
e é o número de gotejadores por planta;

- $q_{n}$ é a taxa mínima de emissão do gotejador, calculada pela pressão mínima no sistema (baseada na curva de relacionamento nominal entre a taxa de descarga do gotejador e a carga hidráu lica), em $1 / \mathrm{h}$;

$q_{a}$ é a taxa média de emissão do gotejador, de to dos os gotejadores em consideração, em $1 / \mathrm{h}$.

A.r relação de $q_{n} \operatorname{com} q_{a}$ expressa o relacionamento da taxa de emissão mínima com a taxa de emis são média. o valor 100 é necessário para converter a re lação em uma porcentagem. O fator, no meio da fórmula, ajusta para a não uniformidade adicional causada pela variação antecipada entre gotejadores individuais, decorrentes do processo de fabricação. A dedução desse ter mo intermediário originou-se de uma consideração da teo ria estatística de uma variável ao acaso distribuida nor malmente.

Os autores usaram a Uniformidade de Emi $\underline{s}$ são (UE) nos procedimentos de projeto como um conceito de eficiência para calcular a lâmina bruta de irrigação, o intervalo de irrigação e a capacidade exigida do sistema. Eles recomendaram que Uniformidades de Emissão (UE's) 
do sistema de $94 \%$ ou mais são desejáveis, e em nenhum caso a Uniformidade de Emissão (UE) dos projetos deveria estar abaixo de $90 \%$

A produtividade e a qualidade da colheita podem ser afetadas tanto pelo excesso de água como pe la falta de água. Portanto, também foi desenvolvido um parâmetro da uniformidade de aplicação que inclui as ta xas de descarga máxima e mínima do gotejador.

Este outro parâmetro de uniformidade, su gerido por KELLER e KARMELI (1974), è a Unïformidade de Emissão Absoluta (UEa), o qual inclui as relações tanto da taxa māxima de fluxo do gotejador como da taxa míni.ma, com a taxa média de fluxo do gotejador.

A Uniformidade de Emissão Absoluta (UẸa)

do projeto é ütil por antecipar a uniformidade geral de emissão dentro do sistema. E um parâmetro que descreve o intervalo esperado de taxas de descarga do gotejador para um dado projeto do sistema de irrigação por gotejo.

Para determinar-se a Uniformidade de Emis são Absoluta (UEa) do projeto, propuseram a seguinte fór mula:

$$
\mathrm{UEa}=100 \cdot\left(1,0-\frac{1,27}{\sqrt{\mathrm{e}}} \cdot \mathrm{CV}_{f}\right) \cdot \frac{1}{2}\left(\frac{\mathrm{q}_{\mathrm{n}}}{\mathrm{q}_{\mathrm{a}}}+\frac{\mathrm{q}_{\mathrm{a}}}{\mathrm{q}_{\mathrm{x}}}\right) \text {, }
$$


onde:

UEa é a uniformidade de emissão absoluta do projeto, em porcentagem;

$\mathrm{q}_{\mathrm{x}}$ é a taxa máxima de descarga do gotejador,ca $\underline{1}$ culada pela pressão máxima no sistema, usando-se a curvà de relacionamento nominal entre a taxa de descarga do gotejador e a carga hidrāulica, em $1 / \mathrm{h}$.

SỌLOMON e KELLER (1978) apresentaram uma tabela que mostra os resultados dos cálculos de UE e UEa para värias situações. Foram considerados pesos numéricos para algumas das observações gerais anteriormente feitas, considerando os histogramas da taxa de fluxo. Mesmo com pequena perda de carga no sistema ou se o expoente de descarga do gotejador elimina a perda de carga da consideração, isto $\vec{e}, x=0$, a Uniformidade de Emissão (UE) pode ainda estar abaixo dos limites aceitáveis se o Coeficiente de Variação do gotejador. para o sistema $\left(\mathrm{CV}_{\mathrm{fs}}\right)$ for muito elevado. 
2.2.3 - Coeficiente de uniformidade de irrigação

A uniformidade de aplicação de :ảgua em sistemas de irrigação pode ser avaliada através de vârios métodos disponiveis para esta finalidade, e KELLER e KARMELI (1974) introduziram um parâmetro especifi camente aplicado em irrigação por gotejo, que é a Uniformidade de Emissão (UE), em porcentagem, no qual: cújas definições usadas foram baseadas em um trabalho similar desenvolvido por HART (1961).

Este autor desenvolveu o modelo de ceficiência de Hart $\left(\mathrm{PE}_{\mathrm{H}}\right)$, que resultou de simplificações ba seadas em definições estatísticas, do Coeficiente de Uniformidade de Christiansen $\left(\mathrm{CU}_{\mathrm{C}}\right)$, que é uma das mais amplamente usadas equações em irrigação por aspersão.

Os tratamentos estatísticos têm a vantagem de simplicidade, em que apenas a táxa média e, ou o desvio padrão, ou o coeficiente de variação, são exigidos para estimar as vârias formas de coeficientes de uniformidade.

SOLOMON (1977) usou o Coeficiente de Variação de Fabricação do gotejador $\left(\mathrm{CV}_{f}\right)$ para descrever estatisticamente a variação na frequência de gotejadores 
dentro de um grupamento de taxas de fluxo ordenadas. A apresentação demonstra dramaticamente como a uniformida de de aplicação de água pode decrescer com um aumento no coeficiente de variação. Há um fator corretivo, contudo, em que a uniformidade pode ser melhorada pelo aumento do nümero de gotejadores por planta, e KELLER e KARM EII (1974) incluiram este termo no cálculo de sua Uniformidade de Emissão (UE) -

NAKAYAMA et alii (1978) desenvolveram um método para mostrar a uniformidade de aplicação de água. pelos gotejadores no sistema de irrigação por gotejo baseado no Coeficiente de Variação de gotejadores, onde é avaliada em termos das taxas de fluxo médias para um subgrupo específico dentro da população total.

Com este tratamento, a taxa de fluxo para qualquer subgrupo poderia ser relacionada com a taxa de fluxo média do grupo total. Em adição, esta descrição pode ser usada para relacionar a variabilidade de descarga do gotejador, ou uniformidade, em uma maneira similar àquela jā desenvolvida para o coeficiente de uni formidade em sistemas por aspersão. Desta forma, com de finições consistentes, critérios apresentados para projetos de irrigação por aspersão podem ser diretamente re lacionados com o sistema de irrigação por gotejo. 
Assïm, os autores utilizaram a definição do Coeficiente de Uniformidade de Christiansen ( $\mathrm{CU}_{\mathrm{C}}$ ) p ra substituir a diferença absoluta entre os valores de vazão observados e a vazão média do total ide observações realizadas, pela diferença absoluta entre a taxa de fluxo média do subgrupo respectivo e a taxa de fluxo média do grupo total, tal que a equação resultaria em um termo que representa o somatório da estimativa da mé dia dos valores da variävel reduzida $\left(\bar{t}_{i}\right)$ para cada res pectivo subgrupo; dividido pelo número de subgrupos usa dos para calcular os valores $\bar{\epsilon}_{i}$. Desta forma chegou-se à equação do Coeficiente de Uniformidade para um projeto de irrigação por gotejo:

$$
\mathrm{CU}_{\mathrm{p}}=\left(1-0,798 \cdot \mathrm{CV}_{\mathrm{f}} / \sqrt{\mathrm{e}}\right) \cdot 100,
$$

onde:

$$
\begin{aligned}
\mathrm{CU}_{\mathrm{p}}= & \text { Coeficiente de Uniformidade do projeto, em } \\
& \text { porcentagem; } \\
\mathrm{CV}_{f}= & \text { Coeficiente de Variação de Fabricação, para } \\
& \text { gotejadores novos, adimensional; } \\
\mathrm{e}= & \text { nümero de gotejadores por planta. }
\end{aligned}
$$

O valor 0,798 foi calculado através do termo que representa o somatório da estimativa da média dos valores da variāvel reduzida $\left(\bar{t}_{i}\right)$ para cada respec- 
tivo subgrupo, dividido pelo número de subgrupos usados para calcular os valores $\bar{t}_{i}$, enquanto que $\mathrm{CV}_{f}$ vem a ser o Coeficiente de Variação de Fabricação para gotejadores novos, que deveria ser fornecido pelo fabricante, e e o número de gotejadores utilizados em cada planta,des de que um único gotejador poderia não ser suficiente pa ra fornecer água às plantas o bastante para encơntrar sua necessidade hídrica diäria.

A equação (3) é similar ao Coeficiente de Uniformidade de Hart $\left(\mathrm{CU}_{\mathrm{H}}\right)$, mas com a introdução do fator $1 / \sqrt{\mathrm{e}}$. Também admite-se existir similaridade na forma entre $\mathrm{CU}_{\mathrm{P}}$ e $\underline{\mathrm{UE}}$, mas a dedução original da Uniformida de de Emissão, de KELLER e KARMELI (1974), è baseada na relação das $25^{\circ}$ menores taxas de fluxo dos gotejadores com a taxa de fluxo média, enquanto que o Coeficiente de Uniformidade, de NAKAYAMA et alii (1978), baseou-se nos desvios da taxa de fluxo média.

Ainda, NAKAYAMA et alii (1978) mostraram que o interrelacionamento entre o Coeficiente de Unifor midade do projeto calculado, o Coeficiente de Variação de Fabricação para o gotejador e o número de gotejadores por planta, pode ser usado como um guia para selecionar o número de gotejadores por planta. Em adição,um Coeficiente de Uniformidade de campo e um Coeficientede 
Variação do gotejador, avaliado no campo, foi relaciona do com a fração de plantas adequadamente irrigadas.

\section{3 - Dispositivos de Emissão (Gotejadores)}

Os dispositivos de emissão ou gòtejadores são estruturas de plástico conectadas às linhas laterais, capazes de dissipar a pressão disponivel na 1inha lateral e de.. aplicar vazões pequenas e constantes. Eles são as peças principais do sistema de iririgação por gotejamento.

Quanto à conexão dos gotejadores na 1 inha laterail, temos, segundo KELLER e KARMELI (1974), go tejadores conectados "sobre", "na" e "no prolongamento" da linha lateral.

As principais características desejāveis nos gotejadores, segundo os autores, são:

- fornecer uma vazão relativamente baixa, constante e uniforme;

- ter umá secção transversal de fluxo relativamente grande, para evitar problemas com entupimento;

- ser barato, resistente e compacto. 
Segundo BERNARDO (1982), a vazao dos gotejadores, em geral, varia entre 1 a $101 / \mathrm{h}$. Normalmente eles trabalham sob uma pressão de serviço de $10 \mathrm{~m}$ de coluna d'água, existindo tipos que trabalham sob pressões menores (até $5 \mathrm{~m}$ de coluna d'água) e outros que tra balham sob maiores pressões (até $30 \mathrm{~m}$ de coluna d'água). Sendo que já existem tipos que trabalham com vazão cons tante sobre uma faixa bem ampla de pressão.

MEYERS e BUCKS (1972) citam que os sistemas de irrigação" por gotejo que trabalham com alta pres são, onde no gotejador ocorre alta perda de carga, tem oferecido a melhor oportunidade para a uniformidade de vazão do gotejador, até o presente momento. Sistemas pre viamente projetados com baixa pressão tem sofrido de de suniformidade de vazão do gotejador, por causa das mu.danças de pressão induzidas por atrito ào longo da linha lateral e representam uma alta porcentagem da pressão total.

Já BERNARDO (1982) comentou que gotejadores de vazão "constante" em uma faixa bem ampla de pres são, possuem uma característica bastante desejável, pois permite uma vazão constante ao longo da linha lateral, independente da variação de pressão ao longo dela.

Como o dimensionamento da linha ilaterà è função da variação de vazão entre o primeiro e o ủiti 
mo gotejador na linha lateral, variação esta que não de ve exceder a $10 \%$ da vazão média dos gotejadores, ao 10 n go da lateral, os gotejadores de vazão constante, sob diferentes pressões, permitem dimensionar sistemas com linhas laterais mais longas, o que diminui o custo do sistema.

Para conseguir uma grande perda de carga e uma taxa de emissão pequena, a secção transversal de fluxo deverā ser normalmente muito pequena, com o seu diâmetro, :em geral, variando entre 0,3 a $1,0 \mathrm{~mm}$, a qual pode entupir facilmente. Aumentando-se a secção transversal do fluxo, para diminuir o problema de entupimento, ocorrerá uma menor perda de energia, com o consequente aumento da vazão.

Por isto, para obter-se uma pequena vazão através de um relativamente grande orifício, ê necessārio reduzir a pressão da água entre a entrada e a saída no. gotejador, de alguma maneira, para dissipar es ta pressão, caso contrário aumentar-se-á em muito a vazão do gotejador. Isto pode ser conseguido de diferentes modos, ou seja, aumentando-se o comprimento de percurso do fluxo, estabelecedendo-se percursos em labirin to, adaptando-se válvulas para controle de vazão, etc., originando-se, assim, os mais variados tipos de goteja- 
jadores .

Os principais tipos de gotejadores, :;segundo BERNARDO (1980), são:

- microtubos;

- gotejador com longo percurso integrado;

- gotejador tipo orifício;

- tubos perfurados, com câmara simples e dupla;

- microgotejadores.

Como as secções transversais de fluxo dos gotejadores são geralmente de diâmetros reduzidos, sua fabricação deverá ser exata e bastante uniforme,pois pequenas variações poderão causar grandes diferenças na vazão.

2.3.1 - Variação na fabricação dos gotejadores

Conforme ressaltado por KELLER e KARMELI (1974), SOLOMON (1976 e 1977) e SOLOMON e KELLER (1978), o fator da variação unidade/unidade com os quais os dis positivos de emissão são fabricados, pode também ter uma maior influência na uniformidade de sistemas de irrigação por gotejo.

0. dispositivo da irrigação por gotejo $\overrightarrow{\mathrm{e}}$ projetado para descarregar água em uma taxa de fluxo 
muito baixa. Por isso, as dimensões críticas do disposi tivo tendem a ser pequenas e difíceis para fabricar pre cisamente. Variações que ocorrem, embora pequenas em $\underline{m a g}$ nitude absoluta, representam uma relativamente grande $\underline{\text { a }}$ riação porcentual. Tambëm, alguns gotejadores utilizam um material elástico para atingir uma compensação de pressão ou capacidade de expulsar a ägua em forma de jạ to ("flushing"), e tais materiais são essencialmente di fíceis de preparar com características e dimensões consistentes.

A menos que, cuidados sejam tomados em sua fabricação, mesmo partes plásticas podem estar sujeitas a variação consideráve1. Há um nümero de variá-. veis de controle para uma máquina de molde, tais como: temperatura e pressão da injeção, velocidade de injeção, temperatura de molde, tempo do ciclo e operações de mo $\underline{1}$ de. Mudanças em qualquer desses fatores causam uma mudança nas condições do plástico que está sendo moldado: temperatura, pressão e taxa de resfriamento. Isto, por sua vez, afetam as características finais da parte produzida: tamanho, forma, peso, resistência e superfície final.

Os resultados de muitos processos de fabricação tendem a ser normalmente distribuídos sobre 
seus valores médios. Portanto é razoảvel tratar a varia ção em taxas de emissão, em uma dada pressão, como uma variāvel distribuída normalmente. 0 total dessa variação é medida pelo Coeficiente de Variação de Fabricação dos gotejadores $\left(\mathrm{CV}_{f}\right)$. 0 valor de $\mathrm{CV}_{f}$ deveria ser proví denciado pelo fabricante do gotejador. Se não o for, po derá ser calculado através de dados obtidos com o Teste de Uniformidade de Vazão do gotejador.

SOLOMON (1977), após tabular valores, em porcentagem, das" taxas de fluxo que desviaram da taxa méciia de fluxo, para quatro dispositivos testados, sendo três gotejadores de fonte de ponto e um de fonte de Iinha, cujos resultados foram baseados em amostras de 50 observações e testados em uma pressão de serviço nor mal para cada dispositivo, concluiu que estes resulta.. dos foram típicos daqueles coletados por muitos disposi tivos de emissão. Também ressaltou que dois importantes pontos a. serem notados são:

(1) alguns dispositivos exibiram considerävel variação unidade/unidade em taxas de fluxo, mesmo quando a pressão de serviço e: temperatura são mantidas constantes; e

(2) o total de variação de fabricação a ser espera do depende do dispositivo particular a ser con siderado. 


\subsection{2 - Coeficiente de varịação de fabricação do gotejador}

Com a crescente tendência para melhorar a uniformidade em projetos do sistema de irrigação por gotejo, a variação na fabricação de um gotejador para outro está tornando-se uma classificacão das mais impor tantes.

Algum método é necessārio para avaliar numericamente esta tendência em direção a variações na taxa de fluxo dos gotejadores, unidade/unidade, devido aos processos de fabricação. As taxas de emissão, em uma dada pressão, para uma grande amostra do modelo do gote jador em questão, deveriam ser medidas.

Recomenda-se que seja adotado como una medida adequada para avaliar o total dessa variação, o Coeficiente de Variação de Fabricação do gotejador $\left(\mathrm{CV}_{f}\right)$, como foi descrito inicialmente por KELLER e KARMELI (1974), e citado por SOLOMON (1977), que vem a ser um termo usado para descrever a variação antecipada na taxa de descarga de uma amostra de gotejadores novos,quan do operados em qualquer dada carga hidrāulica.

o Coeficiente de Variação de Fabricação $\left(\mathrm{CV}_{f}\right)$ pode ser determinado através das taxas de descarga, obtidas pela amostragem de um grupo de gotejadores 
operados em uma carga hidräulica de referência.

o Coeficiente de Variação de Fabriçação do gotejador $\left(\mathrm{CV}_{f}\right)$ foi definido inicialmente por KELLER e KARMELI (1974), da seguinte maneira:

$$
\mathrm{CV}_{f}=\frac{\mathrm{s}}{\overline{\mathrm{q}}}
$$

onde:

$$
\begin{aligned}
\mathrm{CV}_{\mathrm{f}}= & \text { Coeficiente de Variação de Fabricação do go } \\
& \text { tejador, adimensional; } \\
\mathbf{s}= & \text { desvĩo padrão das taxas de fluxo de uma amos } \\
& \text { tra adequada de gotejadores novos, todos ťes } \\
& \text { tados na pressão de serviço norma } 1 \text {, em volu } \\
\cdot & \text { me por unidade de tempo; } \\
\overline{\mathrm{q}}= & \text { estimativa da média das taxas de fluxo da } \\
& \text { amostra assim testada, em volume por unida-- } \\
& \text { de de tempo. }
\end{aligned}
$$

Valores típicos para o Coeficiente de Va riação de Fabricação do gotejador, podem variar de 0,02 a 0,20, apesar de valores mais altos serem observados a gumas vezes.

$$
\text { O significado físico de } \mathrm{CV}_{f} \text { pode ser ex- }
$$
plicado por assumir a distribuição de taxas de emissão, para um dado dispositivo, em pressão de serviço normal, seguir uma distribuição normal\% Então, essencialmente, 
todas as taxas de fluxo observadas cairão dentro de três desvios padrões das taxas de fluxo. Cerca de 95\% das ta xas de fluxo observadas cairão dentro de dois desvios padrões das taxas de fluxo e $68^{\circ}$ cairão dentro de uma vez o desvio padrão das taxas de fluxo.

Da definição do Coeficiente de Variação de Fabricação do gotejador, teremos $s=\mathrm{CV}_{\mathrm{f}} \cdot \overline{\mathrm{q}}$. Estando dentro de 1., 2 ou 3 desvios padrões das taxas de flu xo, implica ter taxas de fluxo dentro dos seguintes 1imites:

$$
\left(1 \pm \mathrm{CV}_{f}\right) \cdot \overline{\mathrm{q}} ;\left(1 \pm 2 \mathrm{CV}_{\mathrm{f}}\right) \cdot \overline{\mathrm{q}} ; ;\left(1 \pm 3 \mathrm{CV}_{f}\right) \cdot \overline{\mathrm{q}},
$$

respectivamente.

SOLOMON (1977) fez várias consideraçôes, que proporcionaram pelo menos uma justificativa informal para supor que as taxas de fluxo dos gotejadores, em uma dada pressão, são distribuídas normalmente:

(1) Primeiro, as distribuições observadas com quatro diferentes dispositivos, pareceram, subjetivamente, estarem próximas da distribuição nor ma1;

(2) Segundo, variações de muitos processos de fabricação tendem a ser normalmente distribuídos sobre seus valores médios. Além disso, a taxa de fluxo de um gotejador pode ser considerada 
como sendo o resultado final de numerosas variáveis ao acaso atuando por todo o processo de fabricação, e o resultado composto tenderá para a normalidade, mesmo se algumas das varia veis individuais são não normais;

(3) Terceiro, apesar de não exigido, a suposição de normalidade é conveniente em termos de cálculos. Uma distribuição normal é caracterizada completamente por sua média e desvio padrão, suas propriedades analiticas são bem conhecidas, e valores tabulados são facilmente disponíveis;

(4) Finalmente, o emprego para os quais essas distribuições serão colocadas, com as inconstâncias e imprecisões inerentes em outras facetas do problema, provavelmente não asseguraria o uso de uma distribuição mais complexa, mesmo se reconhecida ser mais representativa do que a distribuição normal.

A suposição de que a variação das taxas de fluxo de gotejadores, em uma dada pressão, acompanha uma distribuição normal, permite o cálculo da variação esperada nas taxas de fluxo para diferentes Coeficientes de Variação de Fabricação. 
SOLOMON (1977) classificou os gotejadores de acordo com os valores encontrados de $\mathrm{CV}_{f}$, quando determinados conforme o exposto neste item, sugerindo as seguintes interpretações:

\begin{tabular}{cc}
$\mathrm{CV}_{\mathrm{f}}$ & Interpretação \\
$\leq 0,03$ & excelente \\
0,06 & médio \\
0,09 & marginal \\
0,12 & mau \\
$\geq 0,15$ & péssimo \\
\hline
\end{tabular}

o valor de $\mathrm{CV}_{f}$ é usado para calcular a Uniformidade de Emissão do projeto e a Eficiência de Ir rigação do sistema.

SOLOMON e KELLER (1978) relatam que dife renças de fluxo devidas à variação de fabricação podem ser até mais importantes do que diferenças de fluxo devidas às variações de pressão dentro da rede de tubulações, desde que o Coeficiente de Variação de Fabricação $\left(\mathrm{CV}_{\mathrm{f}}\right)$ do gotejador possa ser maior do que 0,10 . 


\section{4 - Relacionamento entre Pressão e Taxa de Fluxo do Gotejador}

KELLER e KARMELI $(1974 \mathrm{a}, \mathrm{b})$ e HOWELL e HI LER (1974) sugeriram que o fluxo de gotejadores podeser caracterizado pela seguinte expressão:

$$
\mathrm{q}=\mathrm{K}_{\mathrm{d}} \cdot \mathrm{H}^{\mathrm{X}},
$$

onde:

$$
\begin{aligned}
\mathrm{q}= & \text { taxa de descarga do gotejador, em } 1 / \mathrm{h} ; \\
\mathrm{K}_{\mathrm{d}}= & \text { coeficiente de descarga, que caracteriza cada } \\
& \text { gotejador, adimensiona } ; \\
\mathrm{H}= & \text { carga hidráulica no gotejador, em m de colu- } \\
& \text { na d'água; } \\
\mathrm{x}= & \text { expoente de descarga, que caracteriza o regi- } \\
& \text { me de fluxo do gotejador. }
\end{aligned}
$$

0 valor de $x$ caracteriza o regime de $f \underline{u}$ xo e o relacionamento da pressão versus descarga do gotejador. Quanto mais baixo o valor de $x$, menos a descar ga será afetada pelas variações de pressão. Em fluxo completamente turbulento, $x=0,5$, e em fluxo laminar, $x=1,0$.

Para gotejadores do tipo orifício de não-compensação e do tipo bocal, são sempre completamente 
. turbulentos, com $x=0,5$. Para gotejadores do tipo compensação de pressão, $0,0 \leq x<0,5$. Contudo, o expoente para gotejadores do tipo longo-percurso pode variar den tro do intervalo $0,5<x \leq 1,0$.

SOLOMON e KELLER (1978) calcularam a dis tribuição de taxas de emissão que ocorriam dentro de sis temas de irrigação por gotejamentó, sob vârias circunstâncias. Supondo um terreno plano, os autores desenvolveram, primeiro, uma expressão geral para a pressão dis ponível em qualquer ponto dentro da rede ide tubulação do sistema. Isto permitiu o cálculo da taxa de fluxo do gotejador a ser esperada em qualquer ponto, baseado na suposta equação da taxa de fluxo do gotejador, descrita anteriormente.

Supondo-se todos os gotejadores funcionando exatamente iguais, como indicado pela equação da taxa de fluxo, esses cálculos determinaram a distribui ção esperada das taxas de emissão dentro do sistema. Es ta é a distribuição das taxas de emissão médias a serem esperadas nas vârias pressóes por todo o sistema. A dis tribuição de taxas de emissão esperadas em cada pressão, devido a variação de fabricação, foi adicionado nesta, dando a distribuição global de taxas de emissão dentro do sistema. 
Ainda os autores, SOLOMON e KELLER (197.8), dizem que é impossível fabricar um lote (ou conjunto) de gotejadores todos com os mesmos valores do Coeficientede Descarga $\left(K_{d}\right)$. As variações resultantes de muitos proces sos de fabricação tendem a ser normalmente distribuídas sobre seus valores médios. Assim, é razoável tratar as variações antecipadas nas taxas de fluxo dos gotejadores, em qualquer dada carga hidráulica, como refletindo uma distribuição normal caracterizada pelo Coeficiente de Va riação de Fabricação $\left(\mathrm{CV}_{f}\right)$ do gotejador. 
3. MATERTAL E METODOS

Este trabalho foi desenvolvido no Labora tório de Hidráulica do Departamento de Engenharia Rural da Escola Superior de/ Agricultura "Luiz de Queiroz" (ESALQ), da Universidade de São Paulo (USP), em Piracicaba .

A finalidade do trabalho foi a de estudar o desempenho hidráulico de três tipos de gotejadores de fabricação nacional, encontrados no comércio com os seguintes nomes: DANTAS, IRTEC e microgotejador IRTEC, e que neste trabalho de dissertação serão denomina dos por DANTAS, IRTEC-1 e IRTEC-2, respectivamente (Figura 1). 

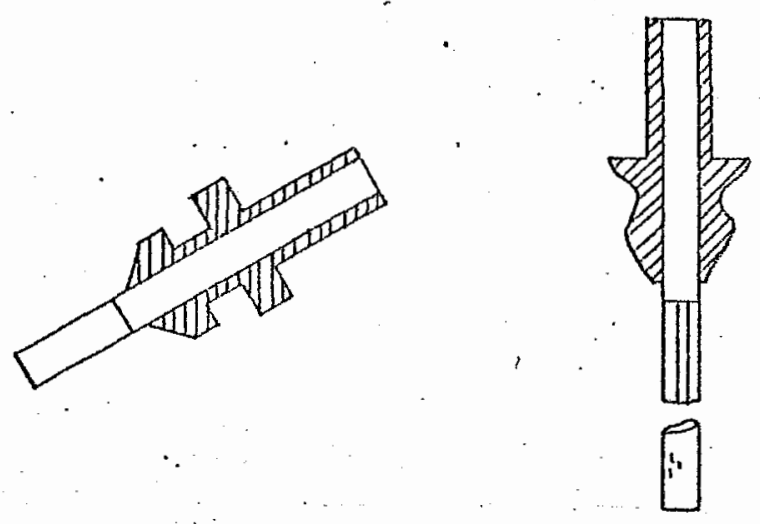

Microgotejador IRTEC

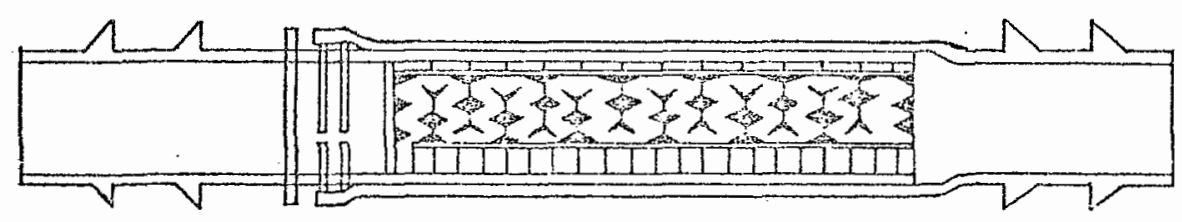

Gotejador DALTAS

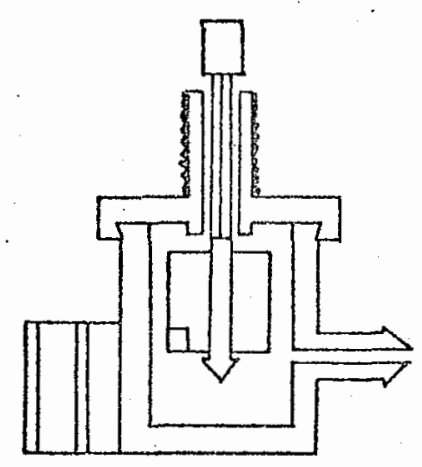

$\therefore \quad$ Gotejador IR'TEC

Figura 1 - Corte longitudinal dos três modelos de gotejadores experimentados. 
3.1 - Descrição do Laboratório de Hidräulica

As instalações do Laboratörio de Hidräulica estão localizadas.no Departamento de Engenharia Ru ral, ESALQ, ocupando uma ārea de $460 \mathrm{~m}^{2}$, e compreende um sistema contínuo de circulação de âgua, constituỉdo por dois reservatórios, sendo um enterrado com capacidade para 22.500 litros e outro elevado com 18.000 1itros de volume, por dois conjuntos moto-bombas, sendo um com capacidade de reçalque de $500 \mathrm{~m}^{3} / \mathrm{h}$ e o outro com uma ca pacidade de $25 \mathrm{~m}^{3} / \mathrm{h}$, e por uma canalização de abastecimento de $150 \mathrm{~mm}$ de diāmetro.

Uma diferença de nível (altura geométrica) de 15,0 metros, entre os espelhos d'água dos reservatórios, confere condições necessārias para o instrumental de pesquisa.

3.2 - Descrição dos Gotejadores

Os gotejadores estudados neste trabalho estão entre os principais tipos de gotejadores relacionados por BERNARDO (1982). As caracteristicas técnicas dos três modelos. de-gotejadores experimentados neste tra balho, segundo os seus fabricantes, são as seguintes: 
Gotejador DANTAS: constitui-se de um corpo composto por duas partes, na qual uma delas, a interna, possui ao longo de seu comprimento câmaras formando ilabirintos para a passagem do fluxo de ảgua, que através de seu relativamente longo percurso, irá fazer com que a ảgua pèrca energia pelo atrito, assim como pela turbulência do fluxo, para, em seu final, sair apenas gotejando. Esta turbulência evita a sedimentação de partícu las contidas na āgua filtrada de irrigação (menores que $0,074 \mathrm{~mm}$ ), evitañdo desta forma as obstruções do goteją dor. 0 gotejador foi especificamente projetado para eli minar entupimentos. A medida que a ägua corre pelo inte rior do gotejador, ao longo da linha de gotejadores, for ma-se um redemoinho que leva os sólidos em suspensão pe 1o centro do fluxo, enquanto o gotejador é alimentado pe la parte externa do redemoinho. 0 modelo de gotejador es tudado apresenta uma capacidade de gotejamento de 4,0 litros por horá, de vazão nominal, a uma pressão de ser viço de 10,0 m de coluna d'água, e oferecido com extremidades que servem para tubos com diâmetro interno nomi nal de $12,0 \mathrm{~mm}\left(1 / 2^{\prime \prime}\right)$. Seu encaixe na linha lateral é do tipo "em 1inha" (Figura 2) e feito a espaçamentos uni formes prë-determinados. 

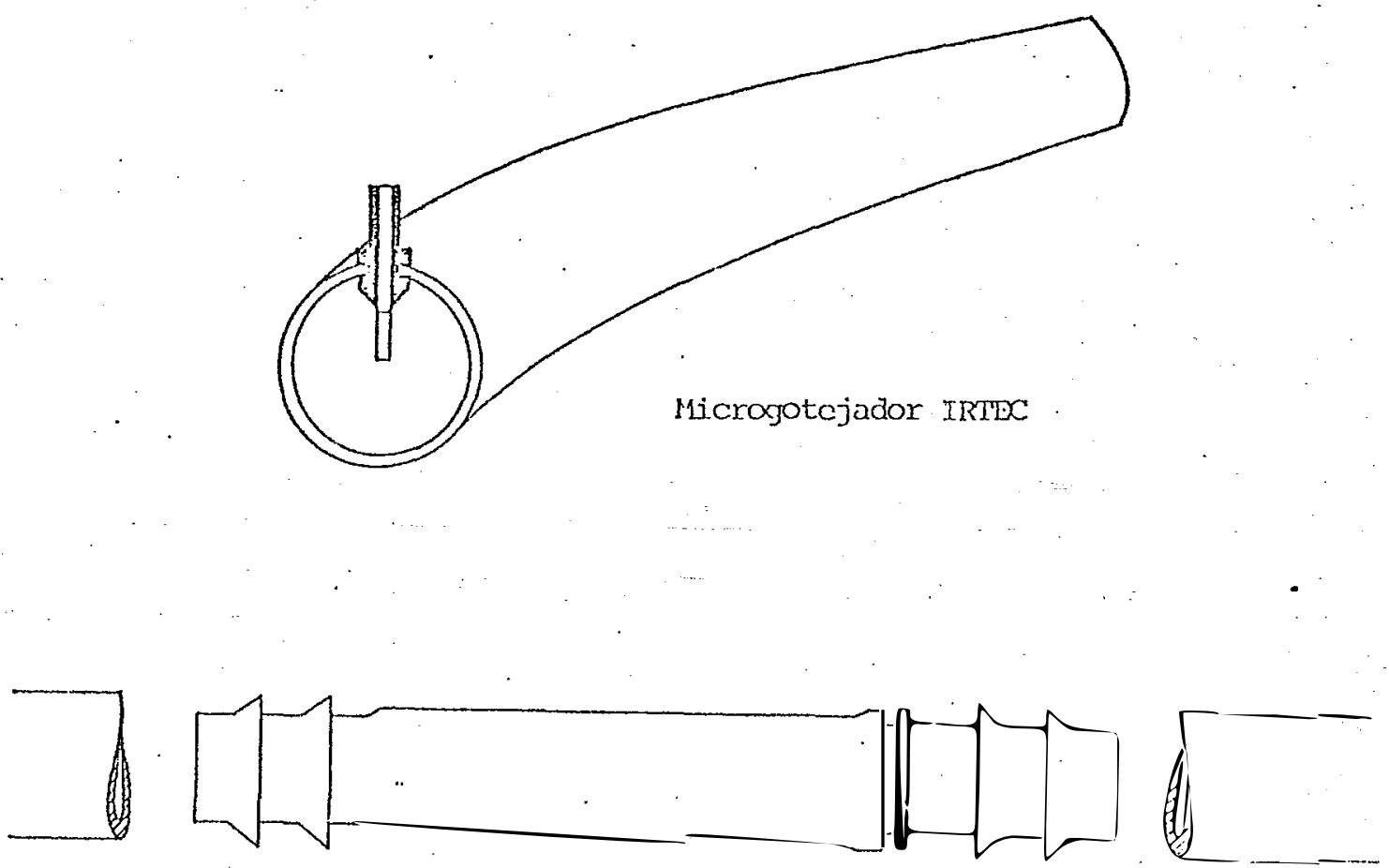

Cotejachor DALITAS

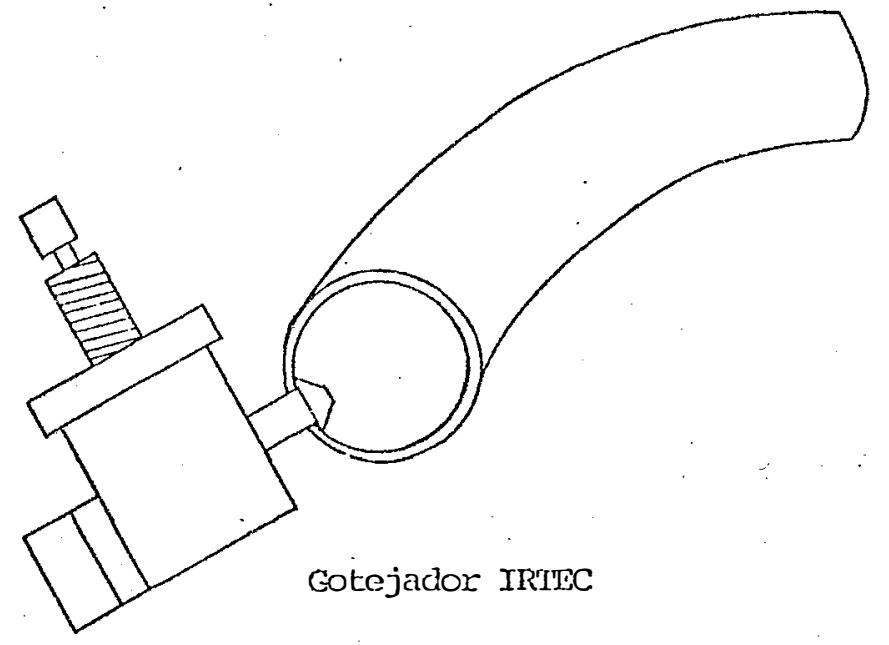

Figura 2 - Tipos de conexões usadas para os três modelos de gotejadores experimentados. 
Gotejador IRTEC: este gotejador, fabricado em copo límero especial e pesando apenas 5 gramas, é constituído de quatro componentes: corpo, tampa, agulha e bucha. Destes, o principal é a bucha, pois na sua parte superior existe um microcanalete que regula o maior ou menor fluxo de ägua para o gotejo. 0 modelo "standard" $\vec{e}$ calibrado para fornecer uma vazão de um galão por hora (3,785 1itros por hora), apresentando a mesma vazão para diferentes pressões, adaptando-se facilmente às possíveis variações"que ocorrem durante a irrigação. Tal vantagem ocorre devido à mobilidade da bucha no interior do corpo do gotejador (funciona como uma bóia). Re comenda-se, na medida do possível, o seu funcionamento no intervalo de 0,5 a $2,0 \mathrm{kgf} / \mathrm{cm}^{2}$. A instalação dos gotejadores na linha lateral, do tipo "sobre linha" (Figu ra 2), é feita através da preparação de orifícios de 1/8" em tubos de polietileno nos seguintes dâametros: 3/8" ou 1/2" ou 3/4", com espaçamentos adequados, colocan do-os através do pino de fixação. Para o modelo de go tejador estudado, utilizou-se uma tubulação de polietileno de $18,0 \mathrm{~mm}$ (3/4") de diâmetro externo nominal, for necendo uma vazão nominal de $3,801 / \mathrm{h}$, a uma pressão de serviço de $10,0 \mathrm{~m}$ de coluna d'ägua. 
Microgotejador IRTEC: este gotejador, de tamanho muito reduzido, $\vec{e}$ auto-regulável, apresentando uma vazão constante de $3,801 / \mathrm{h}( \pm 0,201 / \mathrm{h})$ para variações de pressão de $5,0 \mathrm{~m}$ de coluna d'ägua a $30,0 \mathrm{~m}$ de coluna d'água. Isto é possibilitado pela introdução de um peda ço de silicone na entrada do microgotejador, que com um aumento da pressão interna no tubo fará com que ocorra uma redução na secção transversal da passagem do fluxo. A conexão do microgotejador com a linha lateral é do tí po "sobre linha"," conforme mostra a Figura 2.

\section{3 - Descrição do Sistena}

O sistema utilizado para a realização dos testes constituiu-se dos seguintes componentes:

Banca de Testes: foi construída uma especialmente para a realização dos mesmos, e compunha-se de uma mesa onde foram fixados braços ajustáveis através de peças tipo "borboleta", com a finalidade de manter-se a linha lateral num plano horizontal e na altura da saída da ca nalização de recalque do conjunto moto-bomba.

Conjunto moto-bomba: foi utilizada uma bomba de ma $\underline{x}$ ca KSB, modelo 50/25, fornecendo uma vazão de $25 \mathrm{~m}^{3} / \mathrm{h}$, a uma pressão de $25 \mathrm{~m}$ de coluna d'água, a uma velocida- 
de de 1.710 r.p.m., e com um motor de marca General Ele tric, trifásico, a 60 ciclos e uma rotação de $1.745 \mathrm{r}$. p.m., fornecendo uma potência de $5 \mathrm{CV}$.

Regulador de pressão: utilizou-se um, de marca iㅗ gara, e tendo as seguintes características: tipo 152; ta manho de $1.1 / 2^{\prime \prime}$ de diâmetro para sua entrada e saída; pressão na entrada para até 150 psi $(105,0 \mathrm{~m}$ de coluna d'água): e pressão reduzida dentro da faixa de 10 a 60 psi (7,0 a 42,0 m de coluna d'ägua). A finalidade do re gulador foi a de "regular-se a pressão interna na linha lateral.

Câmara de compressão: instalou-se uma pequena câma ra de compressão logo após o regulador de pressão, tendo 3 " de diâmetro na sua entrada e saída. A altura desta câmara era de cerca de $40,0 \mathrm{~cm}$, e atravês de um tubo plāstico transparente conectado externamente, entre a sua parte inferior e superior, podia-se verificar o nível d'água no interior da mesma. Manteve-se o nível d' âgua numa determinada altura, atravês de uma vālvula de pressão existente em sua parte superior côncava, permitindo a saída do ar contido no interior da câmara, de modo que o volume de água representasse cerca de $2 / 3$ do volume total do mesmo, e o restante (1/3) ficasse preen 
chido com ar. A instalação da câmara de compressão teve por finalidade diminuir as possíveis oscilações do fluxo de água bombeada pelo conjunto moto-bomba, e em decorrência normalizar as oscilações do nível do mercúrio no interior do manômetro, permitindo, dessa forma, leituras mais peecisas da pressão.

Linha lateral: utilizou-se uma linha lateral de po lietileno preto, com um diâmetro nominal externo de 18 mm (3/4") para os gotejadores IRTEC-1 e IRTEC-2, e uma com um diâmetro nominal interno de $12,5 \mathrm{~mm}$ (1/2") para o gotejador DANTAS .

Registros: instalaram-se dois registros, tipo gave ta, de 1/2" de diâmetro, sendo um deles instalado no iní cio da linha lateral e o outro no seu final.

Manômetros: instalaram-se dois manômetros mecânicos, do tipo "Bourdon", entre o regulador de" pressão, tendo por finalidade verificar-se a pressão na entrada e saída do regulador.

Manômetro em "U": construiu-se um manômetro recurvado em "U", com uma altura de $3,0 \mathrm{~m}$, tendo o mercürio como líquido manométrico e com um tubo de plâstico trans parente de $6,0 \mathrm{~mm}$ de diâmetro, fazendo o formado em "U", fixado em uma prancha de madeira. A extremidade final 
deste tubo plástico ficou aberta em contato com a atmos fera, e a extremidade inicial conectada a um bico chanfrado adaptado a uma abraçadeira, a qual foi instalada a $20,0 \mathrm{~cm}$ a montante do ponto onde foi localizado o gotejador. No loçal onde foi conectada a abraçadeira com o bico chanfrado na linha lateral, fez-se um pequeno fu ro com cerca de $1,0 \mathrm{~mm}$, tendo este por finalidade o de colocar a pressão interna da linha em contato com o manômetro recurvado em "U", para ter-se a leitura da pres são na entrada dö gotejador. As leituras obtidas das a 1 turas do mercürio no manômetro foram convertidas para obter-se a carga hidráulica no gotejador em metros de coluna d'água.

Recipiente volumétrico: colocou-se no final da linha lateral, tendo uma capacidade para 1.200 litros e a finalidade de coletar o fluxo de água escoando pela linha lateral, possibilitando a medida da vazão com uma precisão de décimos de milímetros.

Suprimento de ägua: (1) no teste de Uniformidade de Vazão, utilizou-se água proveniente de um reservatơrio elevado a uma altura de 15,0 metros, onde a variação do nível d'água com o sistema em operação atinge $\pm 0,003 \mathrm{~m}$. Deste modo foi realizado o teste descrito adiante, com base numa variação mínima de pressão no sistema; 
(2) no teste para Determinação da Equação Característica de Descarga-Pressão, onde hou ve uma variação de pressão dentro do intervalo de 2,17 $\mathrm{m}$ de coluna d'água $(160 \mathrm{~mm} \mathrm{Hg})$ a $21,21 \mathrm{~m}$ de coluna d'água ( $1.560 \mathrm{~mm} \mathrm{Hg})$, utilizou-se âgua proveniente de um reservatório situado abaixo do piso do laboratório e atravês de um conjunto moto-bomba, descrito anteriormente, recalcou-se a água sob pressão para o sistema.

A bancada de testes, juntamente com a montagem de seus" componentes, são apresentadas nas Figu ras 3 e 4 .

\section{4 - Descrição dos Testes com os Gotejadores}

Efetuaram-se dois tipos de testes, em $\underline{\text { la }}$. boratôrio, com os gotejadores, ou seja: Teste de Unifor midade de Vazão e Teste para Determinação da Equação Ca racterística de Vazão-Pressão.

O detalhe dos gotejadores em funcionamen to, quando da realização dos referidos testes, para os três modelos de gotejadores experimentados, pode servis to na Figura 5. 


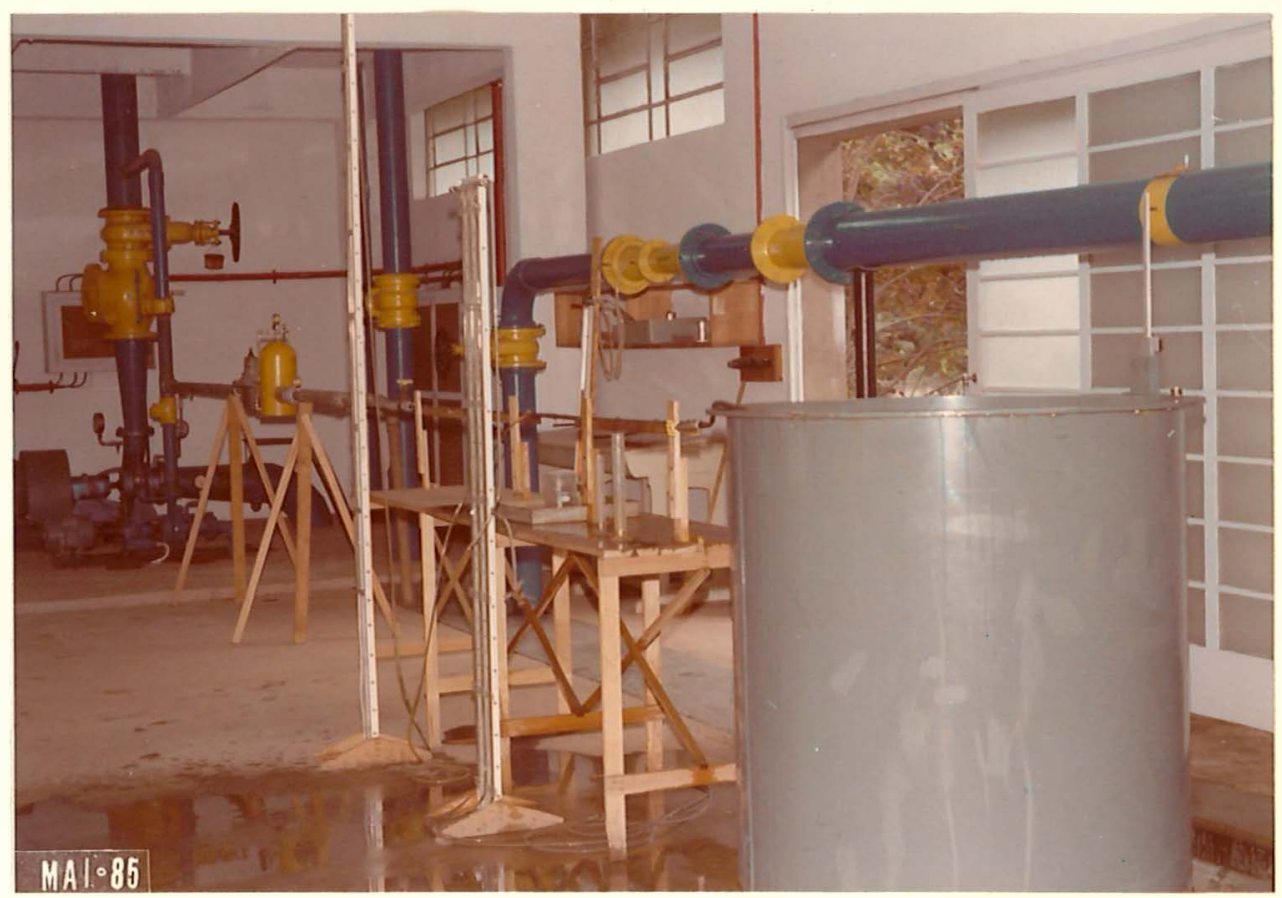

Figura 3 - Vista geral do sistema utilizado jara a realização dos testes.

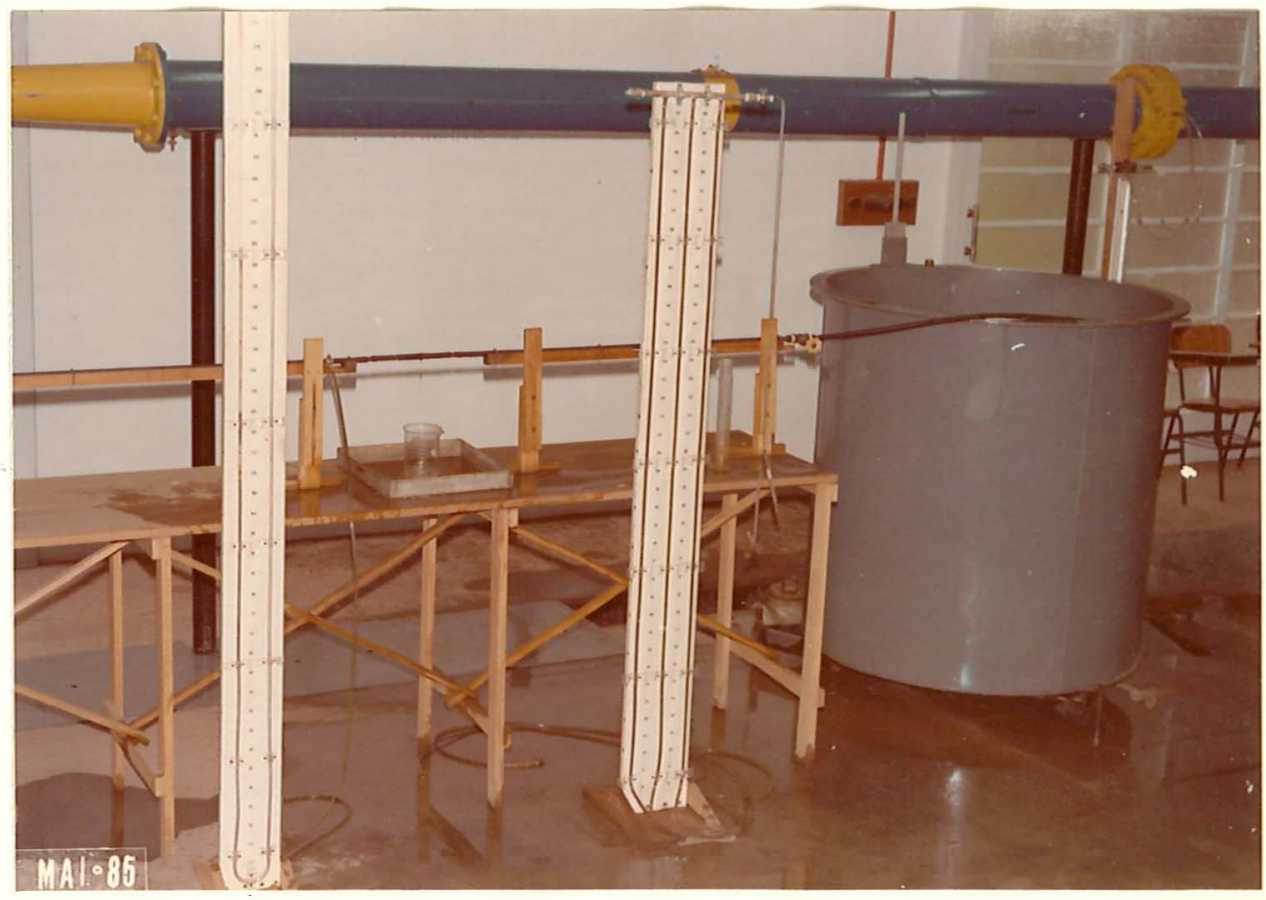

Figura 4 - Vista parcial do sistema, destacando-se a bancada de tes tes, juntamente com o manômetro recurvado em " $U$ "' e o tan que. volumétrico. 


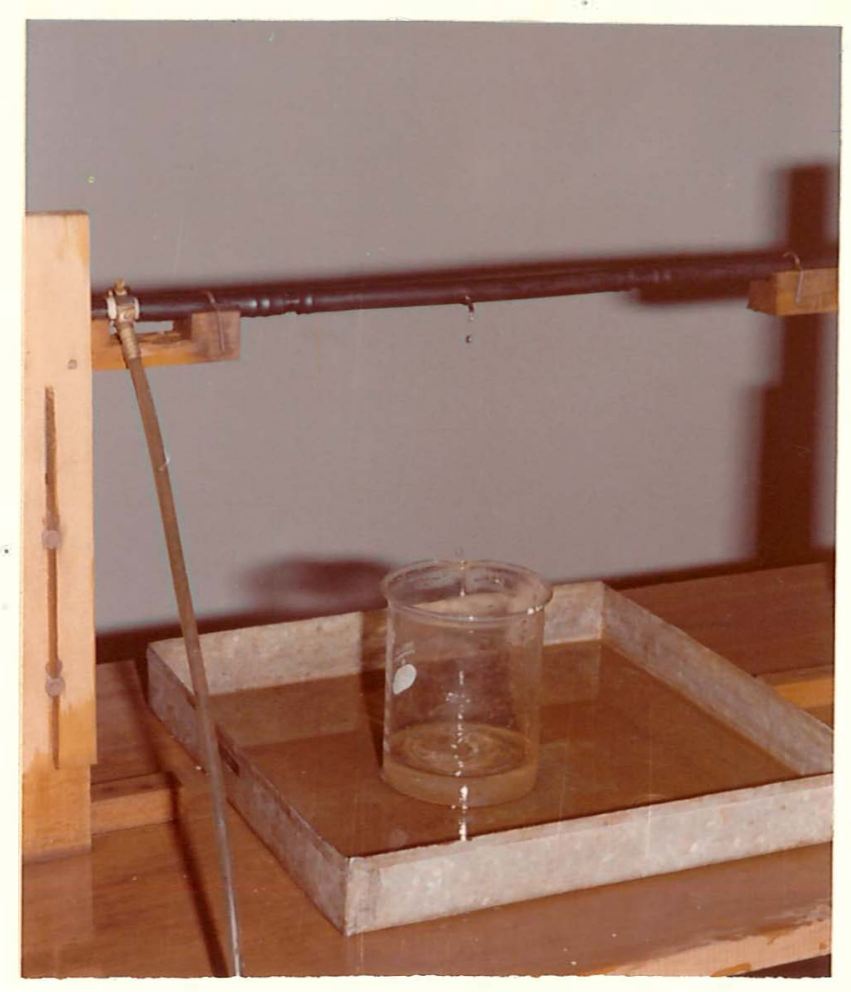

(A) Microgotejaclor IRTEC

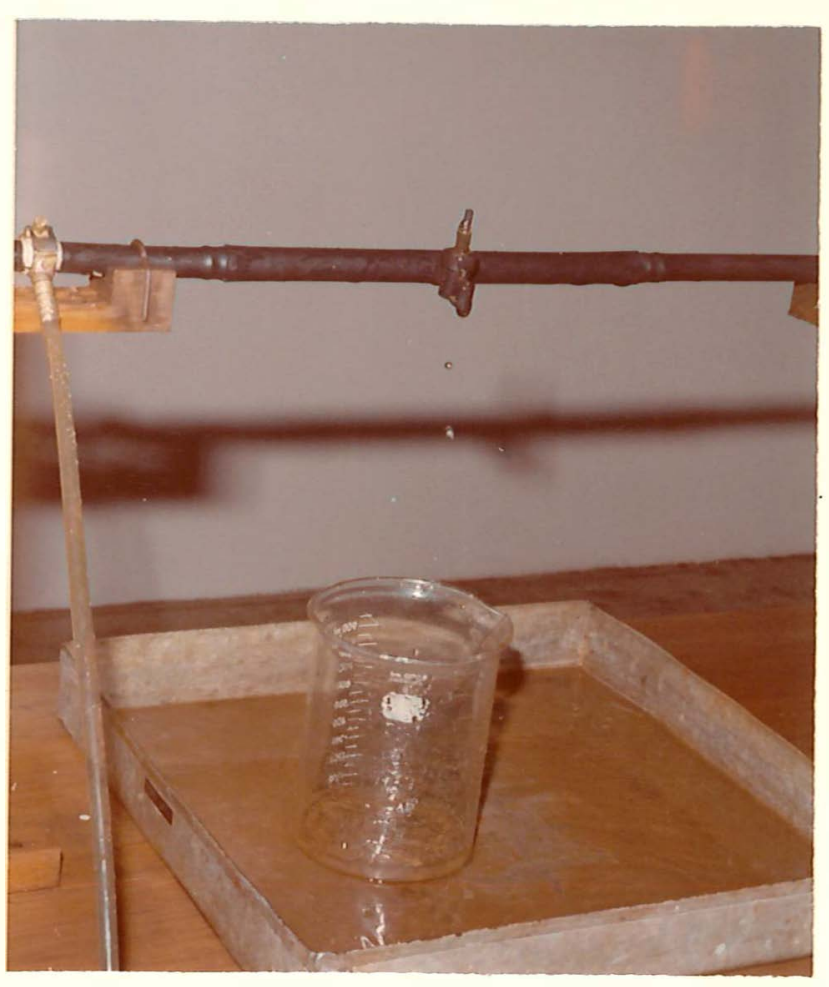

(B) Gotejador IRTEC

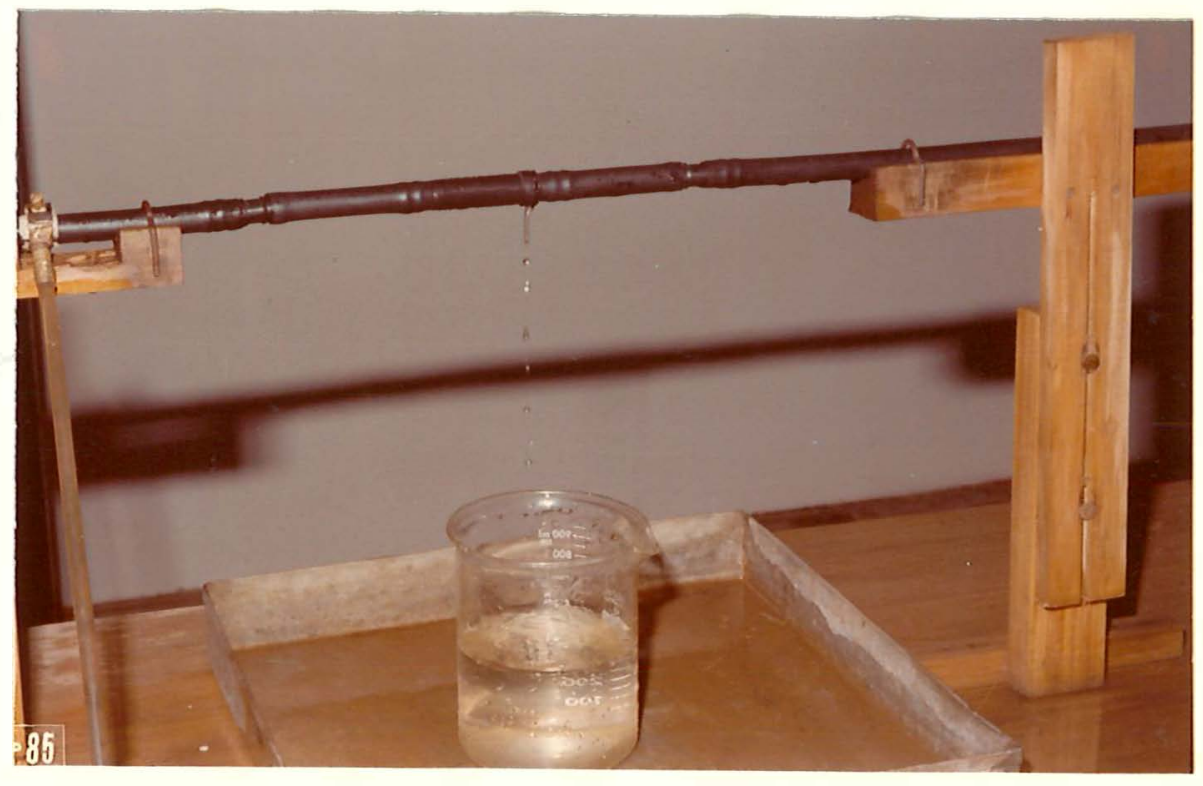

(C) Gotejador DANTAS

Figura 5 - Detalhe dos gotejadores em funcionamento durante a realização dos testes com os três modelọs de gotejadores experimentados. 
56 .

\subsection{1 - Determinação da uniformidade de vazao dos gotejadores}

o objetivo deste teste foi o de verificar a variação existente na taxa de descarga (vazão) en tre os gotejadores amostrados, para cada tipo de goteja dor utilizado no experimento. Esta variabilidade na va$z$ ão dos gotejadores é esperada em razão das diferenças que podem ocorrer entre cada unidade de gotejador duran te o processo de fabricação.

KELLER e KARMELI (1974) e SOLOMON (1977) recomendam que o Coeficiente de Variação de Fabricaşäo $\left(\mathrm{CV}_{f}\right)$ seja adotado como uma medida adequada para determinar-se numericamente esta tendência para com as varia çó̀es de vazão entre os gotejadores, conforme descrito atravẻs da equação (4).

As amostras foram constituídas de 50 (cin quenta) unidades para os gotejadores IRTEC-1 e IRTEC-2, e de 30 (trinta) para o gotejador DANTAS. Paracada amostra formada, os gotejadores foram retirados de um lote contendo 100 (cem) unidades. Cada lote, para cada tipo de gotejador experimentado, foi enviado pela firma fabricante do mesmo com um intervalo de cerca de 3 (três) meses. 
Esses gotejadores amostrados foram conec tados em segmentos de tubo de polietileno, com uma bito la nominal de $3 / 4 "$ x $1,5 \mathrm{~mm}(15,0 \mathrm{~mm}$ de diâmetro nominal interno), para os gotejadores IRTEC-1 e IRTEC-2, e em tubo de polietileno, com uma bitola nominal de $1 / 2$ " $\mathrm{x} 1,0 \mathrm{~mm}(12,5 \mathrm{~mm}$ de diâmetro nominal interno), para o gotejador DANTAS. Todos os segmentos foram cortados com um tamanho de $20,0 \mathrm{~cm}$ de comprimento e numerados em ordem crescente, para cada amostra, de 1 a 50 para os'gotejadores IRTEC-1 e IRTEC- 2 , e de 1 a 30 para os goteja dores DANTAS, respectivamente. Para a realização de cada teste foram retirados, aleatoriamente, os segmentos com os gotejadores numerados, para cada amostra.

Realizaram-se três repetições para os três tipos de gotejadores experimentados, e os valores de vazão de cada gotejador, vazão da linha e temperatura da âgua, foram obtidos calculando-se a média aritmética de três leituras efetuadas simultaneamente, uma após outra. Em cada medida foram registrados os seguintes dados:

Vazão do gotejador: o volume de água descarregado pelo gotejador foi coletado em um "becker" com capacida de de $1.000 \mathrm{ml}( \pm 5 \%$ ), colocado em cima da mesa da banca de testes e embaixo do gotejador, e cronometrado um 
tempo de 3 minutos, por um cronômetro com precisão " de décimos de segundo. A quantidade de ägua foi medida através de uma proveta de $100 \mathrm{ml}$, com precisão de $\pm 1 / 10$ mililitros. A unidade adotada para a vazão do gotejador foi a de litros por hora $(1 / h)$.

Vàzão da linha: o volume de água descarregado pela linha lateral no tanque volumétrico, também num interva 1o de tempo de 3 minutos. Este volume foi obtido através das diferenças de leituras registradas na régua 1inimétrica do tanque volumétrico, em milímetros, multiplicado pela área circular da secção transversal do tan que. A primeira leitura foi obtida após ter-se transcor rido 1 (hum) minuto do início do tempo marcado para obtenção da vazão do gotejador e a segunda obtida após ter-se transcorrido o quarto minuto do tempo inicial. A unidade adotada para a vazão da linha foi a de litros por minuto $(1 / \mathrm{m})$.

Temperatura da água: foi medida em cada leitura, co locando-se um termômetro no "becker" onde recolheu-se o volume de água descarregado pelo gotejador, e retirando-se após o término do terceiro minuto do tempo inicial. A temperatura foi registrada em graus Celsius, através de um termômetro de $0-60^{\circ} \mathrm{C}$, com precisão de $\pm 1^{\circ} \mathrm{C}$. 
Pressão de operação: foi medida atravês do manômetro recurvado em "U", tendo o mercúrio como líquido manométrico, e através do regulador de pressão, instalado a montante da linha de teste, foi mantida a pressão cons tante através da manutenção do mercūrio em determinado níve1 no manômetro, correspondente à pressão de operação do gotejador.

Com os valores obtidos atravês da média aritmética das três leituras efetuadas para cada goteja dor amostrado, cälcularam-se os seguintes parâmetros es tatísticos: a média, o desvio padrão, o erro padrão da média, o Intervalo de Confiança e o Coeficiente de Variação, da vazão do gotejador, da vazão da linha e da temperatura da água, respectivamente, para os 3 (três) testes realizados com cada tipo de gotejador estudado.

Para cada tipo de gotejador, considerando cada teste realizado como um estrato, foram obtidos os seguintes estimadores para os dados globais:

Vazão média global:

$$
\hat{\mathrm{q}}_{\mathrm{g}}=\frac{\Sigma \mathrm{n}_{t} \cdot \overline{\mathrm{q}}_{\mathrm{t}}}{\mathrm{n}} \text {, }
$$

sendo: $\hat{q}_{g}=$ estimativa da vazão média global do gotejador, em $1 / h$; 
60.

$\overline{\mathrm{q}}_{\mathrm{t}}=$ vazão média estimada do gotejador, para cada respectivo teste realizado, em $1 / \mathrm{h}$;

$\mathrm{n}_{\mathrm{t}}=$ nümero de gotejadores amostrados, em cada respectivo teste realizado;

$\mathrm{n}=$ número total de gotejadores amostrados em todos os testes realizados, para cada respectivo gotejador.

Variância da vazão média global:

$$
\forall\left(\hat{q}_{g}\right)=\frac{\sum n_{t} \cdot s_{t}^{2}}{n^{2}},
$$

sendo:

$$
\begin{aligned}
\nabla\left(\hat{\mathrm{q}}_{\mathrm{g}}\right)= & \text { estimativa da variância da vazão mëdia } \\
& \text { global, em } 1 / \mathrm{h} ; \\
\mathrm{s}_{t}^{2}= & \text { variância dos valores de vazão obtidos em } \\
& \text { cada respectivo teste realizado, em } 1 / \mathrm{h} .
\end{aligned}
$$

Erro padrão global:

$$
s\left(\hat{q}_{g}\right)=\sqrt{\hat{v}\left(\hat{q}_{g}\right)},
$$

s endo :

$$
\begin{aligned}
\mathrm{s}\left(\hat{\mathrm{q}}_{\mathrm{g}}\right)= & \text { erro padrão global da mëdia das amostras, } \\
& \text { em } 1 / \mathrm{h} .
\end{aligned}
$$


Intervalo de Confiança Global:

$$
I C C_{g}^{*}=\hat{q}_{g} \pm 2 s\left(\hat{q}_{g}\right)
$$

sendo:

$$
\begin{aligned}
\cdot \mathrm{IC}_{\mathrm{g}}^{*}= & \text { intervalo de confiança global, ao nível de } \\
& 95 \% \text { de probabilidade, em } 1 / \mathrm{h} .
\end{aligned}
$$

Variância Global da Vazão dos Gotejadores:

$$
\mathrm{s}_{\mathrm{g}}^{2}=\frac{\sum \mathrm{q}^{2}-\Sigma \frac{\mathrm{L}_{\mathrm{t}}^{2}}{\mathrm{n}_{\mathrm{t}}}}{\mathrm{n}-1},
$$

sendo:

$$
\begin{aligned}
\mathrm{s}_{\mathrm{g}}^{2}= & \text { estimativa da variância global dos valores } \\
& \text { de vazão obtidos em todos os testes realiza } \\
& \text { dos, para cada gotejador; } \\
\mathrm{q}^{2}= & \text { quadrado dos valores de vazão de todos os } \\
& \text { gotejadores amostrados, em todos os testes } \\
& \text { realizados, em } 1^{2} / \mathrm{h}^{2} ; \\
\mathrm{L}_{\mathrm{t}}= & \text { somatório dos valores de vazão dos goteja- } \\
& \text { dores, obtidos em cada respectivo teste efe } \\
& \text { tuado, em } 1 / \mathrm{h} .
\end{aligned}
$$


Coeficiente de Variação de Fabricação Global:

$$
C V_{f g}=\frac{s_{g}}{\hat{q}_{g}} \times 100
$$

sendo :

$$
\begin{aligned}
\mathrm{CV}_{f g}= & \text { Coeficiente de Variação de Fabricação glo } \\
& \text { bal do gotejador, em porcentagem; } \\
\mathrm{s}_{\mathrm{g}}= & \text { desvio padrão global das amostras de cada } \\
& \text { respectivo gotejador, em } 1 / \mathrm{h} .
\end{aligned}
$$

\section{4 .2 - Determinação da equação característica de vazão-pressão dos gotejadores}

A finalidade deste teste foi a de encon trar-se uma equação que proporcionasse melhor ajustamen to dos dados obtidos durante a realização do mesmo, e que melhor representasse o fluxo de cada tipo de goteja dor em função da carga hidräulica atuando sobre o respectivo dispositivo de emissão.

KELLER e KARMELI (1974) e HOWELL e HILER (1974), sugeriram que o fluxo de gotejadores pode ser caracterizado conforme a expressão descrita através da equação (5).

Para a realização deste teste foi sortea da uma amostra entre as três utilizadas na realização do 
Teste de Uniformidade de Vazão, para cada tipo de gotejador.

Desta amostra sorteada foram retirados 10 (dez) gotejadores, aleatoriamente, e cada um deles foi submetido às pressões de $2,17 \mathrm{~m}$ de coluna d'água, 4,89 m de coluna d'água, 7,61 m de coluna d'água, 10,33 $\mathrm{m}$ de coluna d'água, 13,05 m de coluna d'água, 15,77 m de coluna d'água, 18,49 m de coluna d'água e $21,21 \mathrm{~m}$ de co luna d'água ou correspondentes a $160 \mathrm{~mm} \mathrm{Hg}, 360 \mathrm{~mm} \mathrm{Hg}$, $560 \mathrm{~mm} \mathrm{Hg}, 760 \mathrm{~mm} \mathrm{Hg}, 960 \mathrm{~mm} \mathrm{Hg}, 1.160 \mathrm{~mm} \mathrm{Hg}, 1.360 \mathrm{~mm}$ $\mathrm{Hg}$ e $1.560 \mathrm{~mm} \mathrm{Hg}$, respectivamente.

Para cada gotejador foram feitas 3 (três) leituras da vazão do gotejador, vazão da linha e temperatura da água, tomando-se a média aritmética como sendo o valor representativo da respectiva grandeza para a pressão aplicada no gotejador.

Os dados referentes à vazão do gotejador, vazão da linha latera1, temperatura da água e pressãode operação, foram obtidos da mesma maneira que para o Tes te de Uniformidade de Vazão, conforme descrito anterior mente.

Foi utilizada para a vazão do gotejador a unidade litros por hora $(1 / h)$ e para a vazão da linha a unidade litros por minuto $(1 / \mathrm{m})$, com aproximação cen- 
tesima1, para ambas. A temperatura foi registrada em graus Celsius, com precisão de $\pm 1{ }^{\circ} \mathrm{C}$.

\section{5 - Distribuição de Vazão dos Gotejadores}

Tendo por finalidade visualizar se a dis tribuição dos valores de vazão encontrados para cada amostragem, obtidos no respectivo Teste de Uniformidade de Vazão, para cada modelo de gotejador experimentado, poderia ser considerada como acompanhando uma distribui ção norma1, construiu-se um histograma para cada teste realizado, utilizando-se a relação porcentual entre o valor da vazão do gotejador testado e o valor da vazão média da amostra, para determinar-se a frequência ocorrida em classes com intervalos de $5 \%$, para os gotejadores IRTEC-1 e IRTEC-2, e com intervalos de $3 \%$ para o go tejador DANTAS.

Considerou-se o valor $100 \%$ como sendo 0 valor da vazão média da amostra. Para valores abaixo de . $100 \%$ como sendo os valores de vazão do gotejador abaixo da média e, consequentemente, os valores acima de $100 \%$ como sendo os valores de vazão do gotejador que se encontraram acima da média.

0 teste de Kolmogorov-Smirnov, descrito dentre outros por CAMPOS (1979), foi introduzido para 
adaptação de uma específica e bem conhecida distribuição $F(X)$ a dados provenientes de uma distribuição desconhecida $\mathrm{F}_{\mathrm{O}}(\mathrm{X})$.

A hipótese de nulidade especifica alguma distribuição $F(X)$. Uma amostra $x_{1}, x_{2}, \ldots, x_{n}$ é retira da de alguma população cuja distribuição $F_{O}(X)$ é desconhecida, estabelecendo-se o confronto com $F(X)$ para verificar se é razoável estudar os dados através desta, admitida como a verdadeira função de distribuição da amostra casualizada.

$\mathrm{Na}$ maioria dos casos ele $\vec{e}$ mais poderoso do que o teste de $x^{2}$, principalmente no caso de pequenas amostras.

O teste de Kolmogorov-Smirnov admite uma função de distribuição específica, com média e variância conhecidas.

Para testar-se a normalidade da distribuição dos valores de vazão dos gotejadores, para cada amostra, aplicou-se o teste de Lilliefors, citado, dentre outros, por CAMPOS (1979), que introduziu uma modificação no teste de Kolmogorov-Smirnov, ampliando o seu uso aos casos em que a média e a variância não são espe cificadas, mas, sim, estimadas através dos dados da amos tra. 
Cabe ressaltar que, muitas vezes, a amos tra sabidamente não tem distribuição normal, mas pode-se verificar, através do teste de normalidade, se seria razoável estudar os dados através da distribuição normal, admitida como não discrepante da verdadeira dis tribuição que nos é desconhecida, isto é, as diferenças entre a função de distribuição normal e a verdadeira fun ção de distribuição são insignificantes e, consequentemente, não detectáveis.

Em outras palavras, a aceitação de $\mathrm{H}_{\mathrm{O}}$ não significa que a distribuição padrão seja normal, mas apenas nos indica que esta é uma razoável aproximação da distribuição desconhecida.

De acordo com o teste tomou-se:

$$
\begin{aligned}
\mathrm{F} & =\text { distribuição normal; } \\
\mathrm{F}_{\mathrm{O}} & =\text { distribuição dos dados, que nos é desconhecida; }
\end{aligned}
$$

e as hipóteses:

$$
\begin{aligned}
& \mathrm{H}_{\mathrm{O}}=\mathrm{F} \equiv \mathrm{F}_{\mathrm{O}} ; \\
& \mathrm{H}_{\alpha}=\mathrm{F} \not \mathrm{F}_{\mathrm{o}} ;
\end{aligned}
$$

e ainda a estatística do teste:

$$
D=\sup \cdot\left|F\left(z_{i}\right)-s\left(z_{i}\right)\right|,
$$

admitindo $\mathrm{d}_{\alpha}$ limite superior de tabela ao nivel $\underline{\alpha}$ de pro babilidade, ou seja:

$$
\mathrm{P}_{\mathrm{o}}\left(\mathrm{D} \geq \mathrm{d}_{\alpha}\right)=\alpha
$$


3.6 - Uniformidade de Aplicação dos Gotejadores

\subsection{1 - Uniformidade de Emissão dos gotejado- res na linha lateral}

. 0 desenvolvimento deste tópico tem por ob jetivo a construção de uma tabela que forneça elementos suficientes aos projetistas de sistemas de irrigação por gotejamento, caso utilizem um dos 3 (três) gotejadores experimentados neste trabalho, para que possam dimensio nar o comprimentö de uma linha lateral de irrigação, em função da razão da perda de carga permitida para a linha lateral e do número de gotejadores utilizados por planta, através de um determinado valor de Uniformidade de Emissão (UE) e Uniformidade de Emissão Absoluta (UEa) a serem adotados, os quais devem fornecer uma uniformidade de aplicação aceitável na linha lateral de irrigação por gotejo.

Para a construção desta tabela elaborou-se um programa de computador, cujo fluxograma pode ser visto na Figura 6.

O: procedimento adotado parar à elaboração deste programa foi o seguinte:

- adotaram-se três níveis de pressão de serviço: . $\mathrm{H}_{\mathrm{s} 1}=8,0 \mathrm{~m}$ de coluna d'água; $\mathrm{H}_{\mathrm{s} 2}=10,0 \mathrm{~m}$ de coluna $\mathrm{d}$ '. àgua e $\mathrm{H}_{\mathrm{s} 3}=12,0 \mathrm{~m}$ de coluna d'água; 
68.

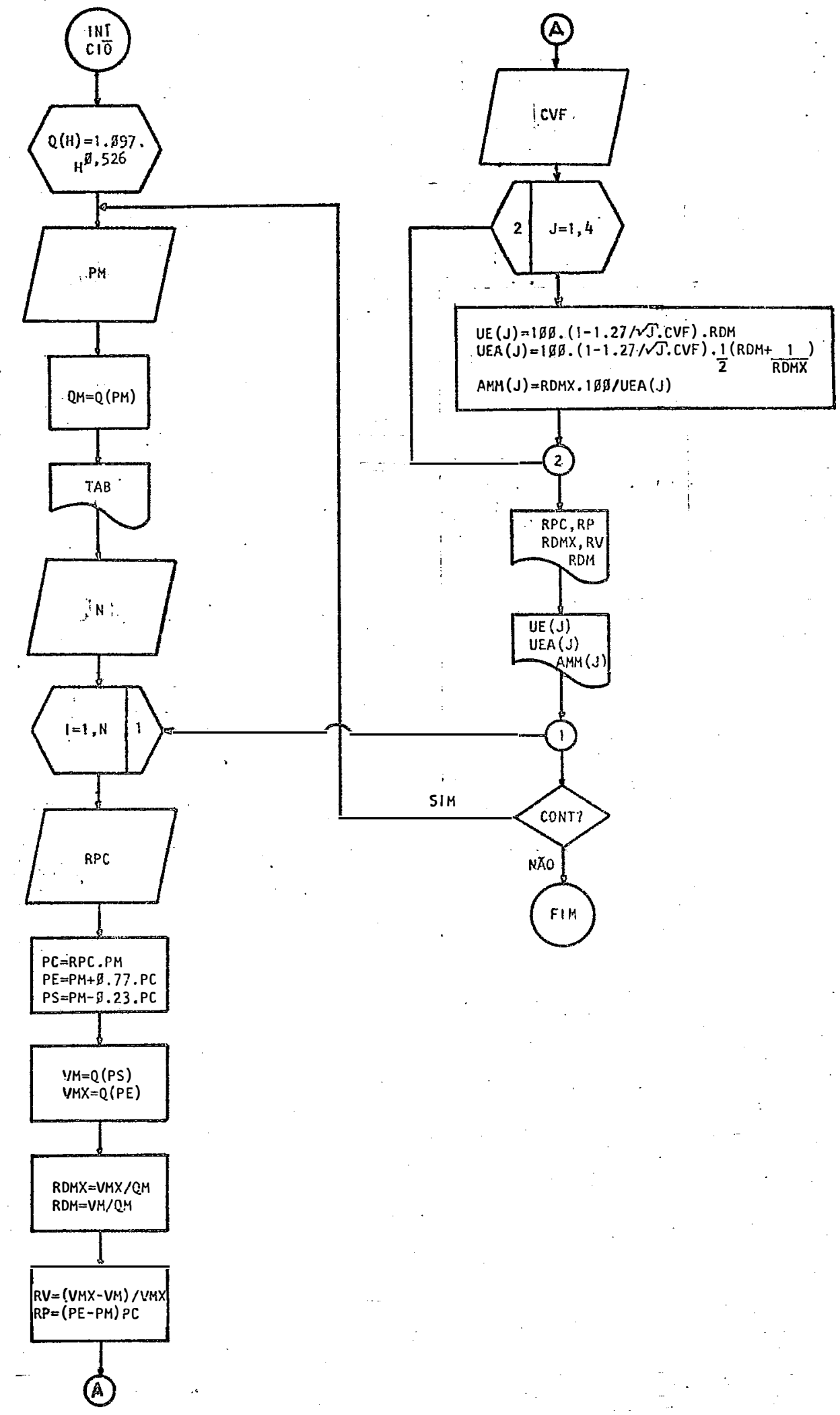

Figura 6 - Fluxograma utilizado para a elaboração da tabela de Uniformidade de Emissão dos gotejadores. 
69.

- com os valores respectivos da pressão de serviço adotada, calculou-se a vazão média $\left(\hat{q}_{m}\right)$ para cada nível de pressão $\left(\hat{\mathrm{q}}_{\mathrm{m} 1}, \hat{\mathrm{q}}_{\mathrm{m} 2}\right.$ e $\left.\hat{\mathrm{q}}_{\mathrm{m} 3}\right)$, considerando-se que a pres são de serviço fornecerá a vazão média da linha lateral, através da equação característica de descarga-pressão de terminada para cada respectivo gotejador;

- adotaram-se 13 (treze) niveis de razão de perda de carga $(R P C=0,05 ; 0,10 ; 0,15 ; 0,20 ; 0,25 ; 0,30 ; 0,40$; $0,50 ; 0,60 ; 0,70 ; 0,80 ; 0,90$ e 1,00$)$, que vem a ser a relação entre a perda de carga a ocorrer na linha lateral e a pressão de serviço adotada:

$$
\mathrm{RPC}=\frac{\Delta \mathrm{H}_{1}}{\mathrm{H}_{\mathrm{S}}},
$$

sendo:

$$
\begin{aligned}
\mathrm{RPC}= & \text { razão de perda de carga, em porcentagem; } \\
\Delta \mathrm{H}_{1}= & \text { perda de carga a ocorrer na linha lateral, } \\
& \text { em m de coluna d'água; } \\
\mathrm{H}_{\mathrm{S}}= & \text { pressão de serviço a ser adotada na linha, } \\
& \text { em m de coluna d'água; }
\end{aligned}
$$

- com os valores adotados da razão de perda de car ga (RPC) e da pressão de serviço respectiva $\left(\mathrm{H}_{\mathrm{S}}\right)$, deter minou-se a perda de carga a ocorrer na linha lateral:

$$
\Delta \mathrm{H}_{1}=\mathrm{RPC} \cdot \mathrm{H}_{\mathrm{s}} \quad \cdot
$$


- a seguir calcularam-se as pressóes na entrada e no final da linha lateral de irrigação, através das seguintes expressões:

$$
\mathrm{H}_{\mathrm{e}}=\mathrm{H}_{\mathrm{S}}+0,77 \cdot \Delta \mathrm{H}_{1},
$$

sendo: $\mathrm{H}_{\mathrm{e}}=$ pressão na entrada da linha lateral, em $\mathrm{m}$ de coluna d'ägua;

$$
\mathrm{H}_{\mathrm{f}}=\mathrm{H}_{\mathrm{S}}-0,23 \cdot \Delta \mathrm{H}_{1} \quad \text {, }
$$

sendo: $H_{f}=$ pressão no final da linha lateral, em $m$ de coluna d'água;

- com os valores da pressão na entrada e no final da linha lateral, calcularam-se os valores da vazão máxima $\left(\hat{q}_{m a}\right)$ e vazão mínima $\left(\hat{q}_{m i}\right)$, respectivamente, atra vés da equação característica de vazão-pressão determinada para cada respectivo gotejador;

- a seguir determinou-se a razão de descarga máxima do gotejador, através da seguinte expressão:

$$
\operatorname{RDMX}=\frac{\hat{\mathrm{q}}_{\mathrm{ma}}}{\hat{\mathrm{q}}_{\mathrm{m}}},
$$

sendo:

$$
\begin{aligned}
\text { RDMX = } & \text { relação entre a vazão máxima e a vazão mé } \\
& \text { dia da linha, adimensiona } 1 ;
\end{aligned}
$$


$\hat{\mathrm{q}}_{\mathrm{ma}}=$ vazão máxima do gotejador, obtida com $\cdot \mathrm{a}$ pressão na entrada da linha latera1, atravês da respectiva equação característica de vazão-pressão, em $1 / \mathrm{h}$;

$\widehat{\mathrm{q}}_{\mathrm{m}}=$ vazão média da linha lateral, obtida com a pressão de serviço adotada, através da res pectiva equação característica de vazão-pressão, em $1 / \mathrm{h}$;

- determinou-se também a razão de descarga mínima do gotejador, através da seguinte expressão:

$$
\operatorname{RDM}=\frac{\hat{\mathrm{q}}_{\mathrm{mi}}}{\hat{\mathrm{q}}_{\mathrm{m}}},
$$

sendo :

RDM = relação entre a vazão mínima e a vazão média da linha, adimensional;

$\hat{\mathrm{q}}_{\mathrm{mi}}=$ vazão mínima do gotejador, obtida com a pressão no final da linha lateral, através da respectiva equação característica de va zão-pressão, em $1 / \mathrm{h}$;

- ainda determinaram-se as seguintes razões:

razão de perda: RP $=\frac{\mathrm{H}_{\mathrm{e}}-\mathrm{H}_{\mathrm{s}}}{\Delta \mathrm{H}_{1}}$, 
sendo: $R P=$ porcentagem (ou razão) da perda de carga ocorrida no trecho entre a pressão na entrada da linha lateral e a pressão de serviço adotada; .

$$
\text { razão de vazão: } R V=\frac{\hat{\mathrm{q}}_{m a}-\hat{\mathrm{q}}_{\mathrm{mi}}}{\hat{\mathrm{q}}_{\mathrm{ma}}} \text {, }
$$

sendo: RV = porcentagem de variação de vazão, em relação à vazão mâxima, ocorrida entre a vazão mâxima e mínima na linha lateral de irriga ção ;

- a seguir determinou-se a Uniformidade de Emissão (UE) para a linha lateral, atravēs da equação (1), proposta por KELLER e KARMELI (1974), onde variou-se o número de gotejadores por planta $\left(\mathrm{e}^{-}=1,2,3\right.$ e 4 gotejadores), para cada valor calculado do Coeficiente de Variação de Fabricação global do respectivo gotejador experimentado:

$$
\mathrm{UE}=100 \cdot\left(1,0-\frac{1,27}{\sqrt{e}} \cdot \mathrm{CV}_{f g}\right) \cdot \mathrm{RDM},
$$

sendo:

$$
\begin{aligned}
\mathrm{UE}= & \text { Uniformidade de emissão de ägua pelos gote- } \\
& \text { jadores na linha lateral, em função do nüme- } \\
& \text { ro de gotejadores por planta, em porcentagem; }
\end{aligned}
$$




$$
\begin{aligned}
\mathrm{e}= & \text { número de gotejadores por planta; } \\
\mathrm{CV}_{\mathrm{fg}}= & \text { coeficiente de variação de fabricação global, } \\
& \text { calculado para cada respectivo gotejador, a- } \\
& \text { dimensional; }
\end{aligned}
$$

- também determinou-se a Uniformidade de Emissão Absoluta (UEà) para a linha lateral, atravês da equação (2), proposta por KELLER e KARMELI (1974), onde variou-se o número de gotejadores por planta $(e=1,2,3$ e 4 gotejadores) para cada valor calculado do Coeficiente de Variação de Fabricação global do respectivo gotejador ex perimentado:

$$
\mathrm{UEa}=100 \cdot\left(1,0-\frac{1,27}{\sqrt{\mathrm{e}}} \cdot \mathrm{CV}_{\mathrm{fg}}\right) \frac{1}{2}\left(\mathrm{RDM}+\frac{1}{\mathrm{RDMX}}\right),
$$

sendo: UEa = Uniformidade de Emissão Absoluta de âgua pelos gotejadores na linha lateral, em fun ção do número de gotejadores por planta, em porcentagem;

- e finalmente determinou-se um parâmetro que nos dará uma idéia de quanto a mais (em porcentagem) deágua estará recebendo a área que tiver o gotejador com vazão máxima, através da expressão seguinte,sugerida por KELLER e KARMELI (1974), que chamaremos por Ārea Mais Mo1hada: 
74.

$$
A M M=(R D M X) \cdot \frac{100}{U E},
$$

sendo: $A M M=$ Area Mais Molhada, em função do nümero de gotejadores por planta, como fator.

\subsection{2 - Coeficiente de Uniformidade na Iinha lateral}

Da metodologia apresentada por NAKAYAMA et alii (1978), onde a uniformidade de aplicação de âgua pelos gotejä̈ores em um sistema de irrigação por go tejo foi baseada no Coeficiente de Variação de gotejado res, è que desenvolveram-se os tópicos a seguir.

Inicialmente, dividiu-se a população total de gotejadores ( $n$ ) relativo às taxas de fluxo do go tejador (q), formada através da reunião das vazões obtí das em cada teste de Uniformidade de Vazão, para cada respectivo gotejador experimentado, em 20 (vinte) subpo pulações ou grupos $\left(Y_{i}\right)$ de nümeros iguais. Alêm disso, a taxa de descarga da população é assumida seguir uma distribuição normal e as descargas dos gotejadores foram ordenadas, tal que o subgrupo $\mathrm{Y}_{1}$ inclui os gotejado res com as menores taxas de fluxo, $\mathrm{Y}_{2}$ as seguintes mais altas taxas de fluxo, e assim por diante, até .o $\mathrm{Y}_{20}$, o grupo com as mais altas taxas de fluxo. 
Assim, com o fator de tamanho fracional da população total e selecionados, os limites iapropríados da variáve1 reduzida ( $t$ ) para o subgrupo especifica do na curva de distribuição normal, um valor médio $\left(\bar{q}_{i}\right)$ para o subgrupo particular pode ser estimado, através da seguinte expressão:

$$
\overline{\mathrm{q}}_{i}=\left(1+C V_{f g} \cdot \overline{\mathrm{t}}_{i}\right) \cdot \hat{\mathrm{q}}_{g},
$$

sendo :

$$
\begin{aligned}
\overline{\mathrm{q}}_{i}= & \text { vazão mẻdia estimada para o respectivo sub- } \\
& \text { grupo, em } 1 / \mathrm{h} ; \\
\overline{\mathrm{t}}_{\mathrm{i}}= & \text { valor médio da variável reduzida para o par } \\
& \text { ticular intervalo do grupo, adjmensional; } \\
\mathrm{CV}_{\mathrm{fg}}= & \text { Coeficiente de variação de Fabricação glo- } \\
& \text { bal do respectivo gotejador, adimensional; } \\
\hat{\mathrm{q}}_{\mathrm{g}}= & \text { estimativa da vazão mêdia global do goteja- } \\
& \text { dor, em } 1 / \mathrm{h} .
\end{aligned}
$$

Quando mais do que um gotejador por plan ta for usado, a nova mëdia para o respectivo i-ésimo gru po serā dada por:

$$
\bar{q}_{i, e}=e \cdot \hat{q}_{g}+\bar{t}_{i} \cdot s_{g} \cdot \sqrt{e},
$$

sendo: 


$$
\begin{aligned}
\overline{\mathrm{q}}_{\mathrm{i}, \mathrm{e}}= & \text { vazão média estimada para o respectivo } \\
& \text { subgrupo, em função do nümero de goteja- } \\
& \text { dores por planta }(\mathrm{e}=1,2,3 \text { e } 4 \text { goteja } \\
& \text { dores }), \text { em } 1 / \mathrm{h} ; \\
\mathrm{s}_{\mathrm{g}}= & \text { desvio padrão global de cada respectivo } \\
& \text { gotejador, em } 1 / \mathrm{h} .
\end{aligned}
$$

Para determinar-se o Coeficiente de Uni formidade na linha lateral de irrigação por gotejamento, empregou-se a equação (3), proposta por NAKAYAMA et alii (1978):

$$
\mathrm{CU}_{\mathrm{LL}}=\left(1-0,798 \cdot \mathrm{CV}_{\mathrm{fg}} / \sqrt{\mathrm{e}}\right) \cdot 100,
$$

sendo: $\mathrm{CU}_{\mathrm{LL}}=$ Coeficiente de Uniformidade na Linha Lateral de irrigação por gotejo, em função do nümero de gotejadores por planta $(e=$ $1,2,3,4,5$ e 6 gotejadores), em porcentagem.

Tambëm, do conceito da "fração da área adequadamente irrigada", usada por Hart e Reynolds, NA KAYAMA et alii (1978) adaptaram-no para estimar a "fra ção de plantas adequadamente irrigadas" para os diferentes Coeficientes de Uniformidade do gotejador. 
$\mathrm{Na}$ apresentação da adaptação daquele con ceito, os autores sugeriram que esta poderia ser simplí ficada para além disso, pelo uso da taxa de fluxo média para as $25 \%$ das menores taxas de fluxo dos gotejadores, como um exemplo, para calcular o tempo corrigido de irrigação ao invés da taxa de descarga média. O tempo total de irrigação neste caso será (e $\left.\cdot \bar{q} / \bar{q}_{25 \%, e}\right)$ vezes o tempo de irrigação baseado na taxa de descarga média do gotejador, onde:

$$
-\frac{\mathrm{e} \cdot \overline{\mathrm{q}}}{\overline{\mathrm{q}}_{25 \%, \mathrm{o}}}=\frac{1}{\left(1-1,27 \cdot \mathrm{CV}_{\mathrm{fg}} / \sqrt{\mathrm{e}}\right)},
$$

sendo: e. $\bar{q} / \bar{q}_{25 \%, e}=$ fator que irâ corrigir o tempo de irrigação, em função do número de gotejadores por planta, : adimensional.

Alêm do mais, a distribuição da frequência acumulada para a variâvel reduzida $t=1,27$ é 0,395, tal que aproximadamente $90 \%$ das plantas poderiam ser es peradas estarem adequadamente irrigadas. Ao invés de $90 \%$ de suficiência de irrigação, a variāvel reduzida $t=1,64$ para $95 \%, t=0,84$ para $85 \%$, etc., podem ser usadas para fixar o tempo corrigido de irrigação. 
78 .

\section{4: RESULTADOS E DISCUSSÃO}

\section{1 - Uniformjade de Vazão dos Gotejadores}

Com a finalidade de verificar-se a varia bilidade de vazão que ocorrerā entre gotejadores de um determinado modelo, quando submetidos a uma carga hidräulica constante e temperatura ambiente da ảgua, variação esta devida a provãveis diferenças existentes en tre cada unidade de gotejador, decorrentes do processo de fabricação, realizou-se o. Teste para Determinação da Uniformidade de Vazão, com 3 (três) repetições, para os três tipos de gotejadores testados.

Nos Quadros 20 a 28 do Apêndice 1, encon tram-se os valores médios dos dados observados de vazão 
do gotejador, vazão da linha lateral e temperatura da água, referentes a 3 (três) leituras realizadas durante cada um dos Testes nos 01, 02 e 03 para determinação da Uniformidade de Vazão, com os gotejadores 'denominados no trabalho por IRTEC-1, IRTEC-2 e DANTAS, quando submetidos a uma pressão constante de $10,33 \mathrm{~m}$ de coluna d'água (760 mm Hg).

Com estes dados calcularam-se os seguin tes parâmetros estatísticos das amostras testadas: mêdia, desvio padrão, erro padrão da média, intervalo de confiança e coeficiente de variação, para a vazão do go tejador, para a vazão da linha lateral e para a tempera tura da água, nos três testes realizados com os gotejadores IRTEC-1, IRTEC-2 e DANTAS. Esses resultados obtidos encontramise nos Quadros 29 a 37 do Apêndice 2, para os testes nos 01,02 e 03 , dos 3 (três) modelos de gotejadores estudados.

\subsection{1 - Gotejador IRTEC-1}

Para o gotejador IRTEC-1 obtiveram-se os seguintes resultados, em relação à vazão do gotejador, para os testes nos 01,02 e 03, respectivamente: 
Quadro 1 - Valores estatísticos relativos à taxa de flu xo do gotejador, à vazão média da linha lateral e à temperatura média da água, obtíclos nos 3 (três) testes realizados com o gotejador IRTEC- 1 .

\begin{tabular}{cccccccc}
\hline \multirow{7}{*}{$\begin{array}{c}\text { TESTE } \\
\text { No }\end{array}$} & \begin{tabular}{c}
$\overline{\mathrm{q}}$ \\
\cline { 2 - 8 }
\end{tabular} & $\begin{array}{c}\mathrm{s} \\
(1 / \mathrm{h})\end{array}$ & $\begin{array}{c}\mathrm{s}(\overline{\mathrm{q}}) \\
(1 / \mathrm{h})\end{array}$ & $\begin{array}{c}\text { I.C. }{ }^{*} \\
(1 / \mathrm{h})\end{array}$ & $\begin{array}{c}\mathrm{CV}_{\mathrm{f}} \\
(1 / \mathrm{h})\end{array}$ & $\begin{array}{c}\overline{\mathrm{Q}} \\
\left(\begin{array}{l}0 \\
0\end{array}\right)\end{array}$ & $\begin{array}{c}(1 / \mathrm{m}) \\
\left({ }^{\mathrm{O}} \mathrm{C}\right)\end{array}$ \\
\hline 01 & 4,74 & 0,78 & 0,11 & $4,52-4,96$ & 16,51 & 17,50 & 19,6 \\
02 & 4,29 & 0,70 & 0,10 & $4,09-4,49$ & 16,41 & 18,66 & 21,8 \\
03 & 3,33 & 0,72 & 0,10 & $3,13-3,53$ & 21,54 & 17,30 & 24,2 \\
\hline
\end{tabular}

sendo: $\bar{q}$ = vazão mẻdia estimada do gotejador, em $1 / h$;

$s=$ desvio padrão da amostra, em $1 / \mathrm{h}$;

$s(\bar{q})=$ erro padrão da média da amostra, em $1 / \mathrm{h} ;$

I.C.* = Intervalo de Confiança da mëdia, ao nível de $95 \%$ de probabilidade, em $1 / \mathrm{h}$;

$\mathrm{CV}_{f}=$ Coeficiente de Variação de Fabricação do go-tejador, em porcentagem;

$\overline{\mathrm{Q}}=$ vazão média da linha lateral, em $1 /$ rn $;$

$\overline{\mathrm{T}}=$ temperatura média da ågua, em graus Celsius.

A vazão média do gotejador, i, encơntrada nas amostras testadas, foi de 4,74 1/h, 4,29 1/h e 3,33 $1 / \mathrm{h}$, para os testes nọs 01,02 e 03 , respectivamente, ve rificando-se que os valores da vazão média $(\bar{q})$ varia- 
ram entre si, havendo uma variação porcentual de $42,3 \%$ entre a maior e menor vazão média, tendo-se como referência a vazão mẻdia menor.

Com relação ao desvio padrão (s) da amostra, nos três testes, a diferença entre os mesmos foi pequena, enquanto que para o erro padrão da média [s $(\bar{q})]$, os valores encontrados nas três repetições podem ser considerados praticamente iguais.

Para o Coeficiente de Variação de Fabricação dos gotejadores $\left(\mathrm{CV}_{f}\right)$ encontraram-se valores praticamente iguais: $16,51 \%$ e $16,41 \%$, para os testes nos 01 e 02 , respectivamente, enquanto que para o teste $n$ ? 03, o valor encontrado $(21,54 \%)$ foi maior em relação aos dọis anteriores (Figura 7).

Os valores encontrados da vazão média da linha lateral (ס) pouco variaram entre si $(17,501 / \mathrm{m}$, $18,661 / \mathrm{m}$ e $17,301 / \mathrm{m}$, respectivamente, para os testes nos 01, 02 e 03), e o Coeficiente de Correlação Linear entre a vazão do gotejador e a respectiva vazão da 1inha lateral, não foi significativo, atravês da aplicação do teste $t$, para os três testes realizados $(r=0,11619$, $\mathrm{r}=0,26004$ e $\mathrm{r}=-0,10775$, respectivamente, para os tes tes nos 01, 02 e 03). 


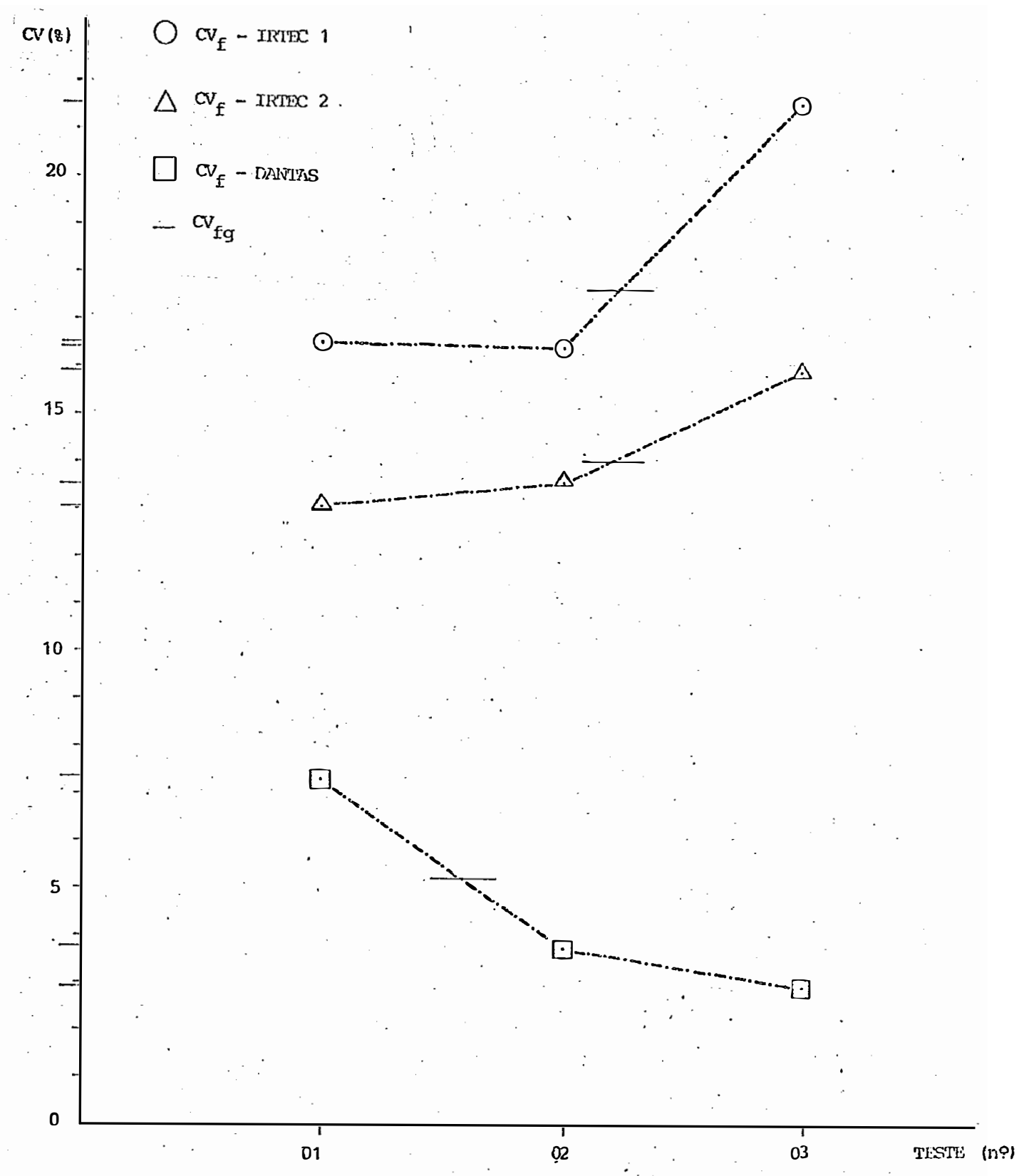

Figura 7 - Valores obtidos do Coeficiente de Variação de Fabricação $\left(\mathrm{CV}_{f}\right)$ para cada teste reajizado, e o valor do Coeficiente de Variação de Fabrica ção global $\left(\mathrm{CV}_{f g}\right)$ do respectivo gotejador. 
Os valores encontrados para a temperatura mêdia da âgua (T) tiveram uma ligeira variação entre si nos três testes realizados $\left(19,6^{\circ} \mathrm{C}, 21,8^{\circ} \mathrm{C}\right.$ e $24,2^{\circ} \mathrm{C}$, para os testes nọs 01,02 e 03, respectivamente), e o Coeficiente de Correlação Linear entre a vazão do gotejador e a respectiva temperatura da água, não foi signi ficativo para os testes nos 01 e $03(\mathrm{r}=-0,26722$ e $\mathrm{r}=$ -0,16767, respectivamente). Para o teste no 02, não foram registrados todos os valores de temperatura ambiente da água, e por este motivo não determinou-se o Coefí ciente de Correlação Linear entre a vazão do gotejador e a respectiva temperatura da āgua, para este teste.

Pelo que foi exposto acima, pode-se depreender que a variação ocorrida na vazão entre os gote jadores foi devida às diferenças existentes entre cada gotejador, decorrentes do processo de fabricação.

Tambëm, devido ao fato de que no testen? 03 o Coeficiente de Variação de Fabricação dos gotejadores $\left(\mathrm{CV}_{f}\right)$ apresentou-se mais alto do que os dos dois testes anteriores (nọs 01 e 02 ), é de se esperar uma variação entre cada lote de gotejadores produzido, se houver alteração nas condições de injeção do plástico para molda gem do gotejador, durante o processo de fabricação dos mesmos, ao longo do tempo. 


\subsection{2 - Gotejador IRTEC-2}

Para o gotejador IRTEC-2 obtiveram-se os seguintes resultados, em relação à vazão do gotejador, para os testes nọs 01, 02 e 03, respectivamente:

Quadro 2 - Valores estatísticos relativos à taxa de flu xo do gotejador, à vazão média da linha late ral e à temperatura média da água, obtidos nos 3 (três) testes realizados com o gotejador IRTEC- 2 .

\begin{tabular}{cccccccc}
\hline \multirow{7}{*}{$\begin{array}{c}\text { TESTE } \\
\text { No }\end{array}$} & $\begin{array}{c}\bar{q} \\
(1 / h)\end{array}$ & $\begin{array}{c}\mathrm{s} \\
(1 / \mathrm{h})\end{array}$ & $\begin{array}{c}\mathrm{s}(\overline{\mathrm{q}}) \\
(1 / \mathrm{h})\end{array}$ & $\begin{array}{l}\text { I.C. } * \\
(1 / \mathrm{h})\end{array}$ & $\begin{array}{c}\mathrm{CV}_{f} \\
\left(\begin{array}{c}0 \\
0\end{array}\right)\end{array}$ & $\begin{array}{c}\overline{\mathrm{Q}} \\
(1 / \mathrm{m})\end{array}$ & $\begin{array}{c}\overline{\mathrm{T}} \\
\left({ }^{\circ} \mathrm{C}\right)\end{array}$ \\
\hline 01 & 5,29 & 0,69 & 0,10 & $5,09-5,49$ & 13,07 & 16,03 & 18,8 \\
02 & 4,97 & 0,67 & 0,10 & $4,78-5,16$ & 13,53 & 18,74 & 22,3 \\
03 & 4,65 & 0,74 & 0,10 & $4,44-4,86$ & 15,91 & 17,48 & 25,3 \\
\hline
\end{tabular}

A vazão média do gotejador, encontrada nas amostras testadas, foi de $5,291 / \mathrm{h}, 4,971 / \mathrm{h}$ e 4,65 $1 / \mathrm{h}$, para os testes nọs 01,02 e 03, respectivamente, ve rificando-se que os valores da vazão média ( $\bar{q})$ variaram entre si, havendo uma variação porcentual de $13,8 \%$ entre a maior e a menor vazão média, tendo-se como referência a vazão média menor. 
Com relação ao desvio padrão (s) da amos tra, nos três testes, a diferença entre os mesmos foi pequena, enquanto que para o erro padrão da média [s( $\bar{q})]$ os valores encontrados foram iguais nas três repetições. Para o Coeficiente de Variação de Fabri cação dos gotejadores encontraram-se valores praticamen te iguais: $13,07 \%$ e $13,53 \%$, para os testes nos 01 e 02 , respectivamente, enquanto que para o teste no 03, o valor encontrado $(15,91 \%)$ foi ligeiramente superior em re lação aos dois anteriores (Figura 7).

Os valores encontrados da vazão média da linha lateral (Q̄) pouco variaram entre si $(16,031 / \mathrm{m}$, $18,741 / \mathrm{m}$ e $17,481 / \mathrm{m}$, respectivamente, para os testes nọs 01, 02 e 03), e o Coeficiente de Correlação Linear entre a vazão do gotejador e a respectiva vazão da linha lateral, foi significativo, ao nível de 1\%, através da aplicação do teste $t$, para o teste no 02, evidencian do uma correlação Iinear positiva $(r=0,37381 * *)$ e não foram significativos para os testes nos 01 e $0.3 \quad(r=$ 0,09192 e $\mathrm{r}=0,09712$, respectivamente).

Os valores encontrados para a temperatura mêdia da ảgua (T) tiveram uma ligeira variação entre si nos três testes realizados $\left(18,8^{\circ} \mathrm{C}, 22,3^{\circ} \mathrm{C}\right.$ e $25,3^{\circ} \mathrm{C}$, para os testes n.os 01,02 e 03 , respectivamente), e o 
Coeficiente de Correlação Linear entre a vazão do gotejador e a respectiva temperatura da água, não foi signi ficativo para os três testes realizados $(r=-0,23417$; $\mathrm{r}=0,25632$ e $\mathrm{r}=-0,05040$, para os testes nọ 01, 02 e 03, respectivamente), indicando não haver influência da temperatura da água na vazão dos gotejadores, para este modelo de gotejador experimentado, dentro da variação de temperatura ocorrida durante a realização dos testes.

Pelo que foi exposto acima, pode-se considerar que a variação ocorrida na vazão entre os gotejadores deve-se às diferenças existentes entre cada gotejador, decorrentes do processo de fabricação.

Também, devido ao fato de que no teste no 03 .o Coeficiente de Variação de Fabricação dos gotejadores $\left(\mathrm{CV}_{f}\right)$ apresentou-se mais alto do que os dos dois testes anteriores (nọs 01 e 02), é de se esperar uma va riação entre cada lote de gotejadores produzido, se hou ver alteração nas condições de injeção do plástico para moldagem do gotejador, durante o processo de fabricação dos mesmos, ao longo do tempo. 


\subsection{3 - Gotejador DANTAS}

Para o gotejador DANTAS obteve-se os seguintes resultados, em relação à vazão do gotejador, pa_ ra os testes nọs 01,02 e 03 , respectivamente:

Quadro 3 - Valores estatísticos relativos à taxa de flu_ xo do gotejador, à vazão média da linha late_ ral e à temperatura média da água, obtidos nos 3 (três) testes realizados com o gotejador DANTAS.

\begin{tabular}{cccccccc}
\hline \multirow{8}{*}{$\begin{array}{c}\text { TESTE } \\
\text { No }\end{array}$} & $\begin{array}{c}\overline{\mathrm{q}} \\
(1 / \mathrm{h})\end{array}$ & $\begin{array}{c}\mathrm{s} \\
(1 / \mathrm{h})\end{array}$ & $\begin{array}{c}\mathrm{s}(\overline{\mathrm{q}}) \\
(1 / \mathrm{h})\end{array}$ & $\begin{array}{c}\text { I.C.* } \\
(\mathrm{I} / \mathrm{h})\end{array}$ & $\begin{array}{c}\mathrm{CV}_{\mathrm{f}} \\
\left(\frac{\mathrm{o}}{0}\right)\end{array}$ & $\begin{array}{c}\bar{Q} \\
(1 / \mathrm{h})\end{array}$ & $\begin{array}{c}\overline{\mathrm{T}} \\
\left({ }^{\mathrm{O}} \mathrm{C}\right)\end{array}$ \\
\hline 01 & 4,21 & 0,31 & 0,06 & 4,$10 ; 4,32$ & 7,35 & 16,95 & 20,7 \\
02 & 3,85 & 0,14 & 0,03 & 3,$80 ; 3,90$ & 3,76 & 17,56 & 22,3 \\
03 & 3,85 & 0,11 & 0,02 & 3,$81 ; 3,89$ & 2,91 & 16,18 & 21,9 \\
\hline
\end{tabular}

A vazão média do gotejador, encontrada nas amostras testadas, foi de $4,211 / \mathrm{h}, 3,851 / \mathrm{h} \mathrm{e} .3,85$ $1 /$ h, para os testes nọs 01,02 e 03 , respectivamente.Ve rificou-se que os valores da vazão média ( $\bar{q})$ foram iguais para os testes nọs 02 e 03 , e 1igeiramente superior para o teste nọ 01, havendo uma variação porcentual de 9,35\% entre a maior e menor vazão mẻdia, tendo-se como 
88 .

referência a vazão média menor.

Tanto para o desvio padrão como ipara o erro padrão da média, observou-se uma ligeira diferença entre os valores encontrados nos três testes, decrescen do do teste n? 01 para o teste no 03.

Para o Coeficiente de Variação de Fabricação dos gotejadores encontraram-se valores bem pröximos: 3,76\% e 2,91\%, para os testes nos 02 e 03, respectivamente, enquanto que para o teste no 01 o valor encontrado $(7,35 \%)$, foi superior em relação aos dois anteráores (Figura 7).

Os valores encontrados da vazão média da linha lateral (Q̄) pouco variaram entre si $(16,951 / \mathrm{m}$, $17,561 / \mathrm{m}$ e $16,181 / \mathrm{m}$, respectivamente, para os testes nọs 01, 02 e 03), e o Coeficiente de Correlação Linear entre a vazão do gotejador e a respectiva vazão da 1inha lateral, não foi significativo para o teste n? 01 $(r=0,28332)$; foi significativo, ao nivel de 5\%, para o teste no 02 , indicando uma correlação linear negativa $\left(r=-0,39209^{*}\right)$, e foi significativo, ao nîvel de $1 \%$, para o teste no 03, evidenciando uma correlação linear negativa $\left(r=-0,59546^{* *}\right)$. Pelos resultados encontrados nos testes nọs 02 e 03, pode-se verificar que há uma ten dência para diminuição da vazão do gotejador quando há 
um aumento na vazão da linha latera 1 , isto para o mode10 de gotejador experimentado, dentro da variação de va zão da linha lateral ocorrida durante a realização dos referidos testes.

Os valores encontrados para a temperatura média da água (T) tiveram uma variação mínima entre si nos três testes realizados $\left(20,7^{\circ} \mathrm{C}, 22,3^{\circ} \mathrm{C} 221,9^{\circ} \mathrm{C}\right.$, para os testes nos 01,02 e 03 , respectivamente), e o Coeficiente de Correlação Linear entre a vazão do gotejador e a respectiva temperatura da água, foi significa tivo, ao nível de 5\%, apenas para o teste no 03, indicando uma correlação linear positiva $\left(r=0,38895^{*}\right)$ e não foi significativo para os testes nos 01 e $02 \quad(r=$ 0,27346 e $r=-0,11572$, respectivamente). Devido à fraca correlação linear existente entre um dos testes, e da não existência de correlação linear entre os outros dois testes, pode-se supor que não há influência direta da temperatura da água na vazão dos gotejadores, para este modelo de gotejador experimentado, dentro da varia ção de temperatura ocorrida durante a realização dos tes tes.

Pelo que foi exposto acima, pode-se depreender que a maior parte da variação ocorrida na vazão entre os gotejadores deve-se às diferenças existen- 
tes entre cada gotejador, decorrentes do processo de fa bricação, embora possa ocorrer uma influência do aumento de vazão na linha lateral na diminuição da vazão do gotejador.

Também, devido aos valores encontrados do Coeficiente de Variação de Fabricação dos gotejadores $\left(\mathrm{CV}_{f}\right)$ apresentarem variações, principalmente no resulta do do teste no 01, em relação aos dois posteriores, pode-se considerar que haverá uma variação entre cada 1ote de gotejadores̈ produzido, se houver alteração nas condições de injeção do plástico para moldagem do gotejador, durante o processo de fabricação dos mesmos, ao longo do tempo.

\subsection{4 - Resultado global}

Com a finalidade de encontrar-se um va-

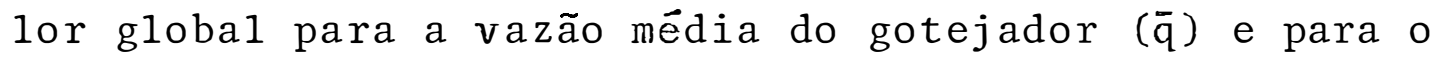
Coeficiente de Variação de Fabricação do gotejador ( $\left.\mathrm{CV}_{f}\right)$, para cada modelo de gotejador experimentado, reuniram-se os valores de vazão do gotejador dos três testes de Uniformidade de Vazão realizados com o referido mode lo de gotejador, quando submetido a uma carga hidráulica constante de $10,33 \mathrm{~m}$ de coluna d'água e temperatura ambiente da āgua. 
Com esses valores reunidos, da vazão do gotejador, para cada modelo experimentado, de acordo com a metodologia citada em 3.4.1, determinou-se a vazão mëdia global do gotejador $\left(\hat{\mathrm{q}}_{\mathrm{g}}\right)$, o erro padrão da média [s $\left(\hat{\mathrm{q}}_{\mathrm{g}}\right)$ ], o Invervado de Confiança (I.C. ${ }_{\mathrm{g}}^{*}$ ), o desvio padrão $\left(s_{g}\right)$ e o Coeficiente de Variação de Fabricação $\left(\mathrm{CV}_{\mathrm{fg}}\right)$.

Os resultados referentes aos três modelos de gotejadores experimentados encontram-se no quadro 4.

Quadro 4 - Valores estatísticos relativos à taxa de flu xo do gotejador, obtidos com os valores reunidos de sua vazão nos três testes realizados, para cada modelo de gotejador experimen tado.

\begin{tabular}{lrccccc}
\hline & \multicolumn{6}{c}{ PARAMETROS } \\
\cline { 2 - 7 } GOTEJADOR & $\mathrm{n}$ & $\begin{array}{c}\hat{\mathrm{q}}_{\mathrm{g}} \\
(1 / \mathrm{h})\end{array}$ & $\begin{array}{l}\mathrm{s}\left(\hat{\mathrm{q}}_{\mathrm{g}}\right) \\
(1 / \mathrm{h})\end{array}$ & $\begin{array}{c}\mathrm{I} . \mathrm{C} . \mathrm{g}^{*} \\
(1 / \mathrm{h})\end{array}$ & $\begin{array}{c}\mathrm{s}_{\mathrm{g}} \\
(1 / \mathrm{h})\end{array}$ & $\begin{array}{c}\mathrm{CV}_{\mathrm{fg}} \\
\left(\begin{array}{l}0 \\
0\end{array}\right)\end{array}$ \\
\hline IRTEC-1 & 145 & 4,12 & 0,06 & $4,00-4,24$ & 0,73 & 17,70 \\
IRTEC-2 & 150 & 4,97 & 0,06 & $4,86-5,08$ & 0,70 & 14,03 \\
DANTAS & 90 & 3,97 & 0,02 & $3,93-4,01$ & 0,21 & 5,17 \\
\hline
\end{tabular}


A vazão média global do gotejador $\left(\hat{\mathrm{q}}_{\mathrm{g}}\right)$ foi de 4,12 1/h, 4,97 1/h e $3,971 / \mathrm{h}$, para os modelos de gotejadores experimentados: IRTEC-1, IRTEC-2 e DANTAS, respectivamente, com uma amostragem de 145,150 e 90 gotejadores, respectivamente.

Para o gotejador IRTEC-1, a vazão média global ( $\hat{\mathrm{q}}_{\mathrm{g}}$ ) foj ligeiramente superior à vazão nominal fornecida pelo fabricante $(3,7851 / \mathrm{h})$, com um Intervalo de Confiança, para a média da amostra, a um nível de 95\% de probabilidade; situando-se entre 4,00 a 4,24 1/h. Já o Coeficiente de Variação de Fabricação global do gutejador $(17,70 \%)$ situou-se numa faixa acima de $15 \%$, segun do a classificação de SOLOMON (1977).

Para o microgotejador IRTEC-2, a vazão mëdia global ( $\hat{\mathrm{q}}_{\mathrm{g}}$ ) foi bem superior à vazão nominal fornecida pelo fabricante $(3,801 / \mathrm{h})$ e superior à vazão mé dia encontrada por FARIA (1981), 4,72 1/h, após a reali zação do Teste de Uniformidade de Vazão, com apenas uma repetição; e com un Intervalo de Confiança, para a vazão mëdia global da amostra, situando-se num intervalo entre 4,86 a 5,08 1/h, a um nivel de probabilidade de 95\%. Já o Coeficiente de Variação de Fabricação global do gotejador $(14,03 \%)$ situou-se numa faixa entre $12 \%$ a 15\%, segundo a classificação de SOLOMON (1977). 
Para o gotejador DANTAS, a vazão média global $\left(\hat{q}_{g}\right)$ foi praticamente igual à vazão nominal fornecida pelo fabricante $(4,001 / \mathrm{h})$ e 1igeiramente abaixo da vazão média encontrada por OLIVEIRA (1978), 4,50 1/h, após a realização do Teste de Uniformidade de Vazão com apenas uma repetição; e com um Intervalo de Confiança, para a vazão média global da amostra situando-se num in tervalo entre 3,93 a $4,011 / h$, a um nivel de probabilidade de 95\%。 Jả o Coeficiente de Variação de Fabricação global do gotejador $(5,17 \%)$ situou-se numa faixa entre 3\% a 6\%, segundo a classificação de SOLOMON (1977). O valor obtido para o Coeficiente de Variação de Fabricação global do gotejador foi praticamente igual ao encon trado por OLIVEIRA (1978), 5,07\%。

Os valores calculados do Coeficiente de Variação de Fabricação global, para cada modelo de gote jador estudado, são relacionados na Figura 7 com os va lores do Coeficiente de Variação obtidos nos três testes de Uniformidade de Vazão realizados com cada respectivo gotejador. 


\section{2 - Distribuição de Vazão dos Gotejadores}

Com a finalidade de verificação de norma lidade da distribuição das taxas de emissão (vazão) dos gotejadores amostrados em cada teste de Uniformidade de Vazão, para cada modelo de gotejador experimentado, aplicou-se o teste de Lilliefors, obtendo-se os seguintes resultados:

Quadro 5 - Resultados do teste de Lilliefors aplicado aos dados de vazão de cada teste realizado, para cada modelo de gotejador.

\begin{tabular}{|c|c|c|c|c|c|}
\hline GOTEJADOR & $\begin{array}{l}\text { Teste } \\
\text { n? }\end{array}$ & $\mathrm{n}$ & $\mathrm{D}$ & $\begin{array}{c}\mathrm{d}_{\alpha} \\
(\alpha=0,05)\end{array}$ & $\begin{array}{l}\text { Significância } \\
\text { estatística }\end{array}$ \\
\hline \multirow[t]{3}{*}{ IRTEC- 1} & 01 & 47 & 0,056 & 0,129 & não rejeitamos $\mathrm{H}_{\mathrm{O}}$ \\
\hline & 02 & 50 & 0,069 & 0,125 & não rejeitamos $\mathrm{H}_{\mathrm{O}}$ \\
\hline & 03 & 48 & 0,069 & 0,128 & não rejeitamos $\mathrm{H}_{\mathrm{O}}$ \\
\hline \multirow[t]{3}{*}{ IRTEC-2 } & 01 & 50 & 0,079 & 0,125 & não rejeitamos $\mathrm{H}_{\mathrm{o}}$ \\
\hline & 02 & 50 & 0,094 & 0,125 & não rejeitamos $\mathrm{H}_{\mathrm{o}}$ \\
\hline & 03 & 50 & 0,104 & 0,125 & não rejeitamos $\mathrm{H}_{\mathrm{o}}$ \\
\hline \multirow[t]{3}{*}{ DANTAS } & 01 & 30 & 0,248 & 0,161 & rejeitamos $\mathrm{H}_{\mathrm{O}}$ \\
\hline & 02 & 30 & 0,316 & 0,161 & rejeitamos $\mathrm{H}_{\mathrm{O}}$ \\
\hline & 03 & 30 & 0,259 & 0,161 & rejeitamos $\mathrm{H}_{\mathrm{O}}$ \\
\hline
\end{tabular}


Os histogramas dos três testes realizados, para cada modelo de gotejador experimentado, encon tram-se nas Figuras 8,9 e 10.

Com a construção dos histogramas e com a aplicação do teste de Lilliefors, para verificação da normalidade à distribuição dos dados de vazão dos gotejadores amostrados em cada teste de Uniformidade de Vazão, para cada modelo de gotejador experimentado, constatou-se que:

(1) Para o gotejador IRTEC-1, os valores de sua taxa de fluxo (vazão), nos três testes realizados, distribuiram-se, praticamente, entre ós pontos médios de $68 \%$ a $133^{\circ}$, o que representa uma variação de vazão de $32 \%$ abaixo da vazão média $(\bar{q})$ e de $33 \%$ acima da vazão média $(\bar{q})$. A dispersão dos valores de vazão não foi uni forme em relação à vazão média das amostras, ao longo do intervalo das linhas de distribuição, porém a apiicação do teste de Lilliefors revelou que os dados podem ser estudados através da distribuição normal.

(2) Para o gotejador IRTEC-2, os valores de sua ta xa de fluxo (vazão), nos três testes realizados, distrí buíram-se, praticamente, também, entre os pontos médios de $68 \%$ a $133 \%$, o que representa uma variação de vazão de $32 \%$ abaixo da vazão média $(\bar{q})$ e de $33 \%$ acima da vazão 

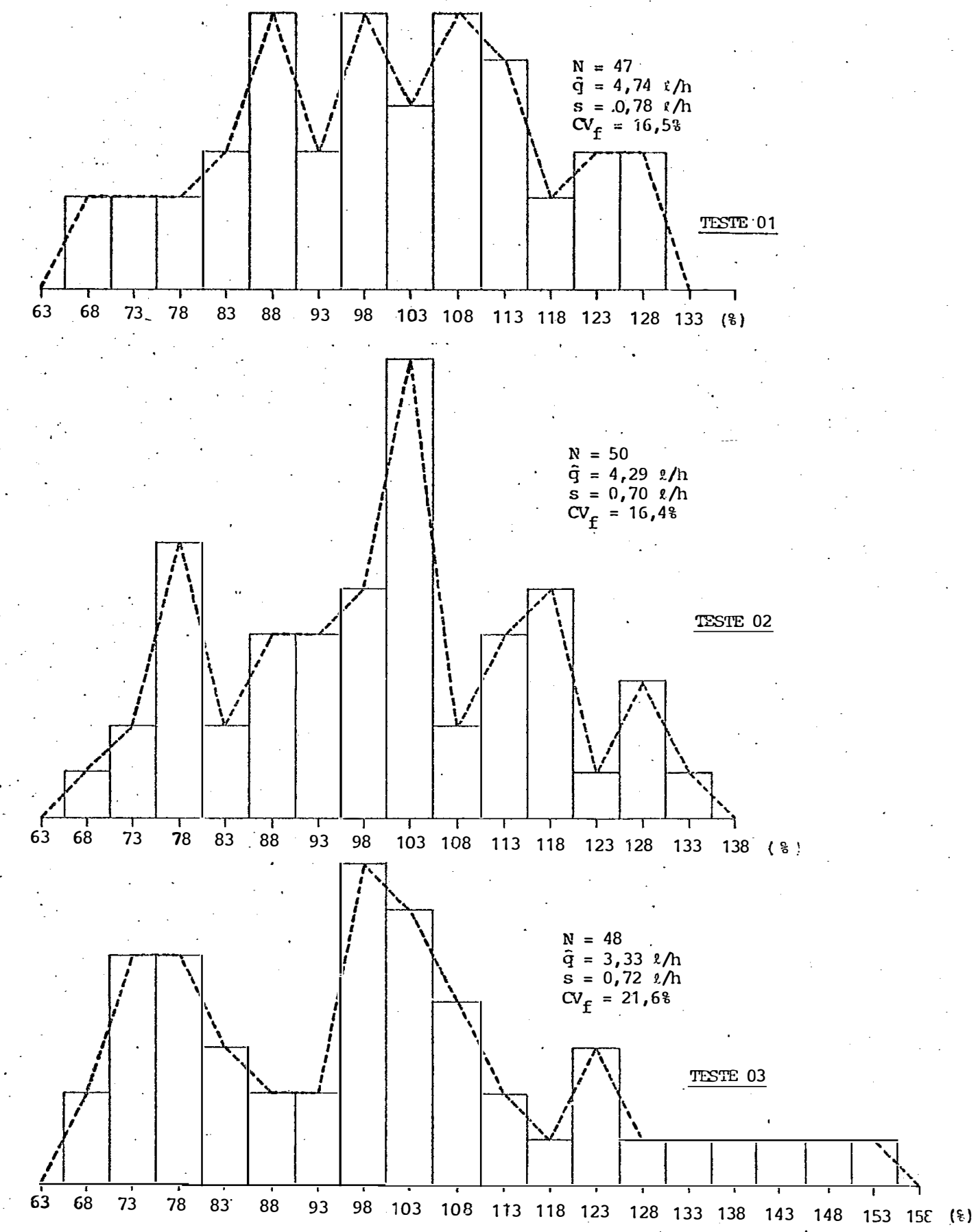

Figura 8 - Histogramas referentes aos dados de vazão dos gotejadores, obtidos nos três testes de Uniformidade de Vazão realizados com o gotejador IRTEC- 1 . 

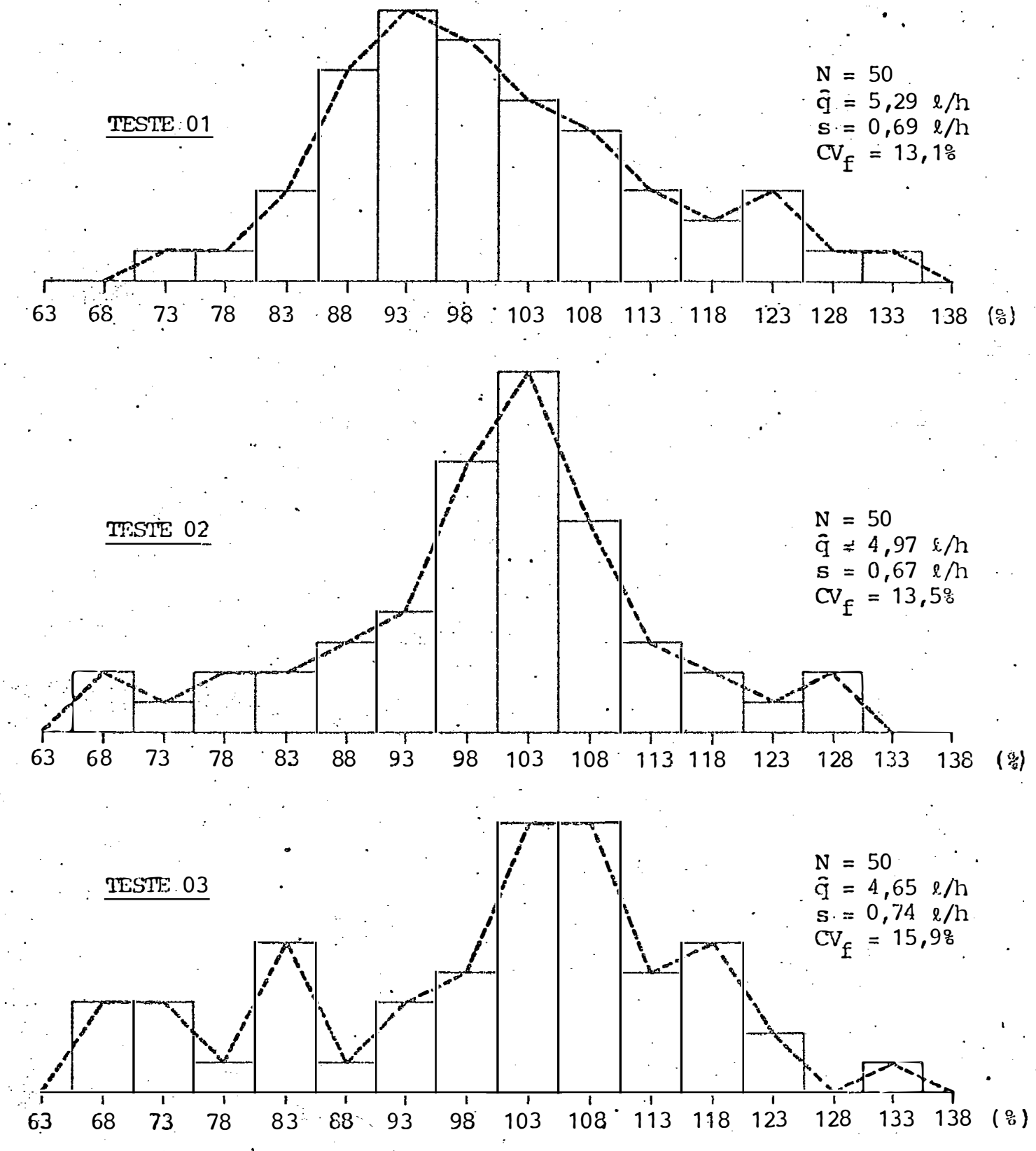

Figura 9 - Histogramas referentes aos dados de vazão dos gotejadores, obtidos nos três testes de Uniformidade de Vazão realizados com o gotejador IRTEC- 2 . 
98 .
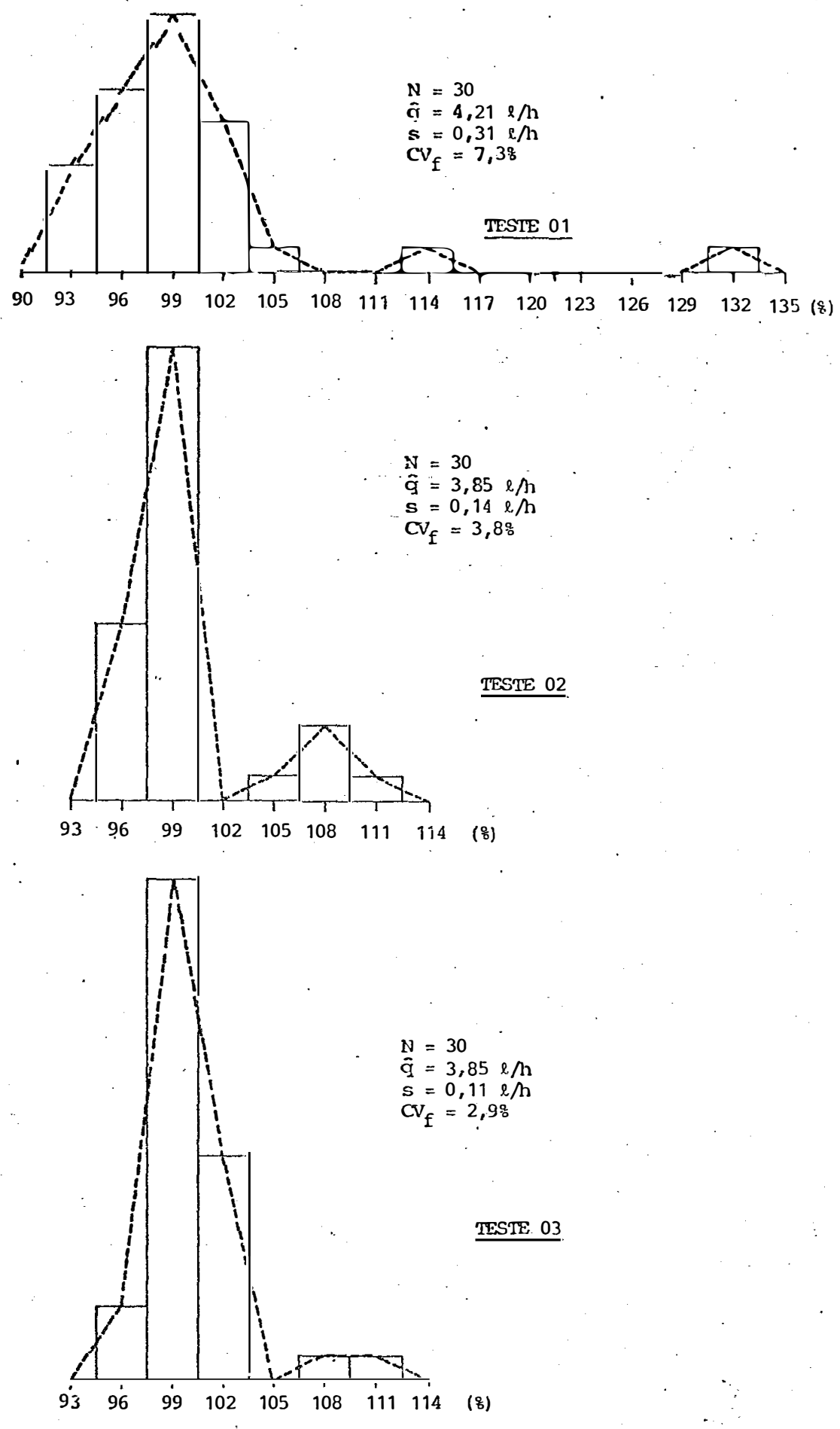

Figura 10 - Histogramas referentes aos dados de vazão dos gotejadores, obtidos nos três testes de Uniformidade de Vazão realizados com o gotejador DANTAS. 
média $(\bar{q})$. A dispersão dos valores de vazão, porém, foi mais uniforme em relação à vazão média das amostras, ao longo do intervalo das linhas de distribuição, do que em comparação ao gotejador IRTEC-1. A aplicação do teste de Lilliefors revelou que os dados podem ser estu dados atravês da distribuição normal.

(3) Para o gotejador DANTAS, os valores da sua taxa de fluxo (vazão), nos três testes realizados, distri buíram-se, praticamente, entre os pontos médios de 93\% a $111 \%$, o que representa uma variação de vazão de $7 \%$ abaixo da vazão média $(\bar{q})$ e de $11 \%$ acima da vazão média $(\bar{q})$. A dispersão dos valores de vazão teve uma concentração representativa ao redor do valor da vazão média das amostras, ao longo do intervalo das linhas de distribuição. A aplicação do teste de Lilliefors revelou uma não aderência dos dados à distribuição normal proposta.

\section{3 - Equação Característica de Vazão-Pressão do Go- tejador}

Com a finalidade de se encontrar uma equa ção característica que melhor representasse a variação de vazão em função das pressões aplicadas no gotejador, realizou-se o Teste para Determinação da Equação Carac- 
terística de Vazão-Pressão, submetendo-se 10 (dez) gotejadores a 8 (oito) diferentes pressões, sob temperatura ambiente da âgua.

Os gotejadores testados foram retirados, aleatoriamente, de uma das amostras utilizadas para a realização do Teste de Uniformidade de Vazão, para cada modelo de gotejador experimentado.

$$
\text { Os valores médios das } 3 \text { (três) leituras }
$$

correspondentes aos dados observados de vazão dos gotejadores, quando submetidos a diferentes pressões, referentes aos gotejadores IRTEC-1, IRTEC-2 e DANTAS, encon tram-se, respectivamente, nos Quadros 38,39 e 40 do Apêndice 3 .

\subsection{1 - Anālise da variância}

Com os valores médios dos dados observados de vazão dos gotejadores, fez-se uma análise da variância, considerando-se cada gotejador como sendo um bloco e para cada diferente pressão aplicada como sendo os tratamentos efetuados a cada gotejador.

Os resultados dessa anâlise da variância podem ser vistos no Quadro 6, para os 3 (três) gote jadores experimentados: IRTEC-1, IRTEC-2 e DANTAS, respectivamente. 
Quadro 6 - Análise da variância realịzada com os valores médios dos dados observados de vazão dos gotejadores IRTEC-1, IRTEC- 2 e DANTAS, quando submetidos a 8 (oito) diferentes pressões.

Gotejador IRTEC-1:

\begin{tabular}{lrrrc}
\hline Causas de Variação & G.L. & iS.Q. & Q.M. & F \\
\hline Gotejadores (G) & 9 & 52,6360 & 5,8484 & $7,67^{* *}$ \\
Pressões (P) & 7 & 7,0883 & 1,0126 & $1,33^{\text {ns }}$ \\
Resíduo & 63 & 48,0242 & 0,7623 & \\
\hline Total & 79 & 107,7485 & & \\
\hline
\end{tabular}

Gotejador IRTEC-2:

\begin{tabular}{lrrrc}
\hline Causas de Variação & G.L. & S.Q. & Q.M. & F \\
\hline Gotejadores (G) & 9 & 49,0149 & 5,4461 & $42,82^{* *}$ \\
Pressões (P) & 7 & 11,5664 & 1,6523 & $12,99 * *$ \\
Residuo & 63 & 8,0140 & 0,1272 & \\
\hline Tota1 & 79 & 68,5953 & & \\
\hline
\end{tabular}

Gotejador DANTAS:

\begin{tabular}{lcrrr}
\hline Causas de Variação & G.L. & S.Q. & Q.M. & \multicolumn{1}{c}{ F } \\
\hline Gotejadores (G) & 9 & 0,0272 & 0,0030 & $4,29^{* *}$ \\
Pressões (P) & 7 & 117,6258 & 16,8037 & $24005,28^{* *}$ \\
Resíduo & 63 & 0,0415 & 0,0007 & \\
\hline Total & 79 & 117,6945 & \\
\hline$* *$ Significativo ao níve1 & de $1 \%$ de probabilidade; \\
ns = Não significativo.
\end{tabular}


Para o gotejador IRTEC-1, a anālise reve lou que o efeito dos gotejadores, considerados como blo cos, sobre a variação de vazão ocorrida foi significati vo ao nível de $1 \%$, para o teste $F$, e que o efeito das diferentes pressões, consideradas como tratamentos, sobre a variação de vazão ocorrida não foi significativo para o teste F. Isto quer dizer que as diferenças existentes entre cada unidade de gotejador foram responsâveis pela variação de vazão ocorrida nos gotejadores du rante a realização do teste e que as diferentes pressões aplicadas não influíram significativamente na alte ração da vazão dos gotejadores.

Para o microgotejador IRTEC-2, a anālise revelou que o efeito dos gotejadores, considerados como blocos, sobre a variação de vazão ocorrida foi significativo ao nível de $1 \%$, para o teste $F$, e que o :efeito das diferentes pressões, consideradas como tratamentos, sobre a variação de vazão ocorrida também foi significa tivo ao nível de $1 \%$, para o teste F. Isto revela uma di ferença de comportamento tanto dos gotejadores como das pressões.

Para o gotejador DANTAS, a anälise revelou que o efeito dos gotejadores, considerados como blo cos, sobre a variação de vazão ocorrida foi significatí 
vo ao níve1 de $1 \%$, para o teste $F$, e que, também o efei to das diferentes pressões, consideradas como tratamentos, sobre a variação de vazão ocorrida foi significatí vo ao níve1 de $1 \%$, para o teste F. Isto quer dizer que a variação de vazão ocorrida entre os gotejadores foi tanto influenciada pelas diferenças existentes entre ca da unidade de gotejador, como, principalmente, pelo efeito das diferentes pressões aplicadas em cada gotejador.

\section{3 .2 - Equação geomētrica}

Com a intenção de estabelecer uma equação de fluxo do gotejador em função da pressão atuando sobre o mesmo, conforme a equação (5) sugerida por KELLER e KARMELI (1974) e HOWELL e HILER (1974), foram usa das as médias aritméticas calculadas com os 10 (dez) va lores médios dos dados observados de vazão dos gotejado res, quando testados a uma determinada pressão. (Apêndice 3).

Portanto, obteve-se oito pares de valores (pressão no gotejador versus vazão mẻdia dos goteja dores), ordenando-os em ordem crescente de pressão, con forme mostram os Quadros 7,8 e 9, para os gotejadores IRTEC-1, IRTEC-2 e DANTAS, respectivamente, e a seguir 
Quadro 7 - Média dos valores médios dos dados observados de vazão dos gotejadores, vazão da linha lateral e temperatura d'água, para o gotejador IRTEC-1, quando submetido a diferentes pressões.

\begin{tabular}{cccccc}
\hline PRESSAO (H) & & $\begin{array}{c}\overline{\mathrm{q}} \\
(1 / \mathrm{h})\end{array}$ & $\begin{array}{c}\overline{\mathrm{Q}} \\
(1 / \mathrm{m})\end{array}$ & $\begin{array}{c}\mathrm{T} \\
\left({ }^{\circ} \mathrm{C}\right)\end{array}$ \\
\hline 2,17 & 160 & 3,20 & 6,84 & 21,15 \\
4,89 & 360 & 3,71 & 9,91 & 21,20 \\
7,61 & 560 & 3,91 & 12,46 & 21,55 \\
10,33 & 760 & 3,75 & 14,53 & 21,65 \\
13,05 & 960 & 3,58 & 16,42 & 21,40 \\
15,77 & 1.160 & 3,37 & 17,98 & 21,55 \\
18,49 & 1.360 & 3,28 & 19,55 & 21,40 \\
21,21 & 1.560 & 2,97 & 20,71 & 21,40 \\
\hline
\end{tabular}

sendo: $\mathrm{H}$ = pressão ou carga hidräulica na entrada do gotejador, em m de coluna d'água ou mnn de mercúrio;

$\bar{q}=$ vazão média referente aos valores médios dos dados observados de vazão dos gotejadores, em $1 / \mathrm{h}$;

$\bar{Q}=$ vazão média referente aos valores médios dos dados observados de vazão da 1 inha lateral, em $1 / \mathrm{m}$;

$\overline{\mathrm{T}}$ = temperatura média referente aos valores médios dos dados observados da temperatura ambiente d'água, em ${ }^{\circ} \mathrm{C}$. 
Quadro 8 - Média dos valores médios dos dados observados de vazão dos gotejadores, vazão da linha lateral e temperatura d'água, para o gotejador. IRTEC-2, quando submetido a diferentes pressões.

\begin{tabular}{|c|c|c|c|c|c|}
\hline \multicolumn{3}{|c|}{ PRESSÃO (H) } & \multirow{2}{*}{$\begin{array}{c}\vec{q} \\
(1 / h)\end{array}$} & \multirow{2}{*}{$\begin{array}{c}\bar{Q} \\
(1 / \mathrm{h})\end{array}$} & \multirow{2}{*}{$\left(\begin{array}{c}\mathrm{T} \\
\left({ }^{\mathrm{O}} \mathrm{C}\right)\end{array}\right.$} \\
\hline (m de & coluna d'ägua) & $(\mathrm{mm} \mathrm{Hg})$ & & & \\
\hline & 2,17 & 160 & 3,09 & 5,38 & 18,90 \\
\hline & 4,89 & 360 & 3,92 & 7,96 & 19,20 \\
\hline & 7,61 & 560 & 4,16 & 10,02 & 19,25 \\
\hline & 10,33 & 760 & 4,34 & 11,58 & 19,40 \\
\hline & 13,05 & 960 & 4,30 & 12,97 & 19,45 \\
\hline & 15,77 & 1.160 & 4,27 & 14,37 & 19,60 \\
\hline & 18,49 & 1.360 & 4,12 & 15,51 & 19,75 \\
\hline & 21,21 & 1.560 & 4,07 & $1.7,35$ & 19,83 \\
\hline
\end{tabular}


Quadro 9 - Mêdia dos valores mëdios dos dados observados de vazão dos gotejadores, vazão da linha lateral e temperatura d'âgua, para o gotejador DANTAS, quando submetido a diferentes pressões.

\begin{tabular}{|c|c|c|c|c|c|}
\hline \multicolumn{3}{|c|}{ PRESSAOO $(\mathrm{H})$} & \multirow{2}{*}{$\begin{array}{c}\bar{q} \\
(1 / h)\end{array}$} & \multirow{2}{*}{$\begin{array}{c}\bar{Q} \\
(1 / \mathrm{m})\end{array}$} & \multirow{2}{*}{$\begin{array}{c}\mathrm{T} \\
\left({ }^{\mathrm{O}} \mathrm{C}\right)\end{array}$} \\
\hline$(\mathrm{m} \mathrm{de}$ & coluna d'āgua) & $(\mathrm{mm} \mathrm{Hg})$ & & & \\
\hline & 2,17 & 160 & 1,62 & 8,46 & 22,40 \\
\hline & 4,89 & 360 & 2,57 & 12,57 & 22,50 \\
\hline & 7,61 & 560 & 3,23 & 15,68 & 22,60 \\
\hline & 10,33 & 760 & 3,76 & 18,18 & 22,60 \\
\hline & 13,05 & 960 & 4,25 & 20,68 & 22,30 \\
\hline & 15,77 & 1.160 & 4,68 & 22,71 & 22,40 \\
\hline & 18,49 & 1.360 & 5,05 & 24,53 & 22,60 \\
\hline & 21,21 & 1.560 & 5,41 & 25,85 & 22,70 \\
\hline
\end{tabular}


tirando-se os logaritmos dos respectivos valores de pres são e vazão.

Com os logaritmos das pressões ap1icadas e das vazões médias calculadas, estruturou-se a equação de regressão linear, estabelecendo-se uma função de $\underline{f l \underline{u}}$ xo ou equação característica de vazão-pressão para cada modelo de gotejador experimentado.

Transformando-se a equação logarítmica ajustada, para uma equação do tipo geométrica, obtiveram-se as seguintes equações para os 3 (três) tipos de gotejadores estudados:

IRTEC-1:

$$
\hat{\mathrm{q}}=3,680 \cdot \mathrm{H}^{-0,028},
$$

IRTEC-2:

$$
\hat{\mathrm{q}}=3,108 \cdot \mathrm{H}^{0}, 112
$$

DANTAS:

$$
\hat{\mathrm{q}}=1,097 \cdot \mathrm{H}^{0}: 526
$$

em que: $\hat{q}$ = vazão média estimada do gotejador, em $1 / \mathrm{h}$; $\mathrm{H}=$ pressão na entrada do gotejador, em $m$ de coluna d'água. 
A representação grāfica das três equações anteriores, em escala decimal e logarítmica, encon tram-se nas Figuras 11, 12 e 13, para os gotejadores IR TEC-1, IRTEC-2 e DANTAS, respectivamente.

Procedeu-se a uma anālise dè :regressão

para os 3 (três) modelos de gotejadores estudados, sendo utilizada cada respectiva equação geométrịca determi nada [equações (27), (28) e (29), respectivamente para os gotejadores IRTEC-1, IRTEC-2 e DANTAS], chegando-se aos seguintes resultados:

Gotejador IRTEC-1:

Para o gotejador IRTEC-1, a regressão foi significativa a nível de $1 \%$, para o teste F, obten do-se um coeficiente de determinação $\left(r^{2}\right)$ igual a $0,90429^{* * *}$. Devido a este coeficiente ser alto, o que significa que cerca de $90_{0}^{\circ}$ da variação ocorrida foi explicada por esta equação, confere aos valores obtidos da vazão média dos gotejadores testados, para cada pressão aplicada,te rem um ajustamento adequado à equação determinada.

\section{Gojetador IRTEC-2:}

Para o gotejador IRTEC-2, a regressão foi significativa ao nível de $1 \%$, para o teste F, obtendo-se um coeficiente de determinação $\left(r^{2}\right)$ igual a $0,96100 * *$. 

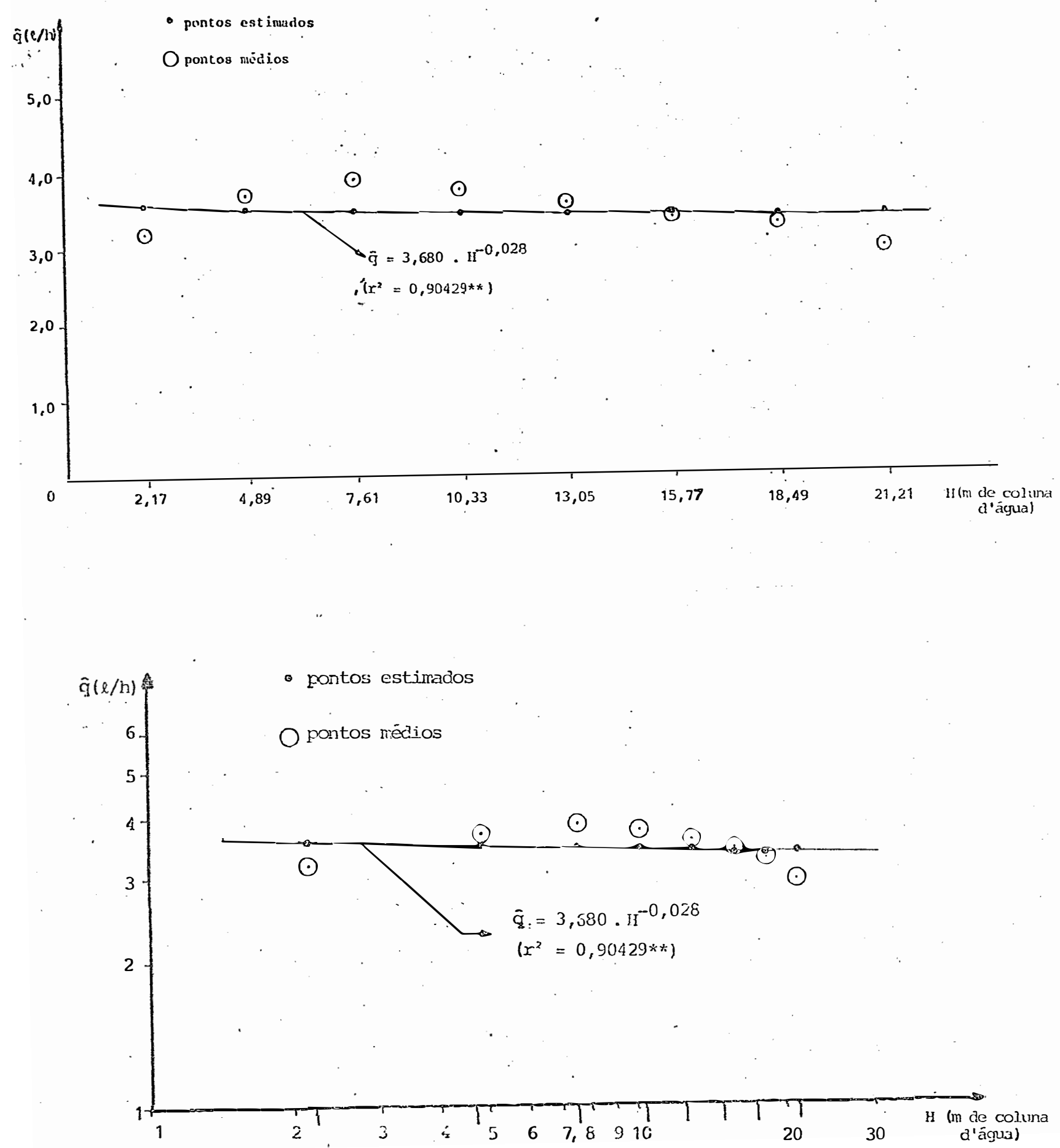

Figura 11 - Representação gráfica da curva obtida para a equação geométrica determinada para o goteja dor IRTEC-1, em escala decimal e logarítmica. 

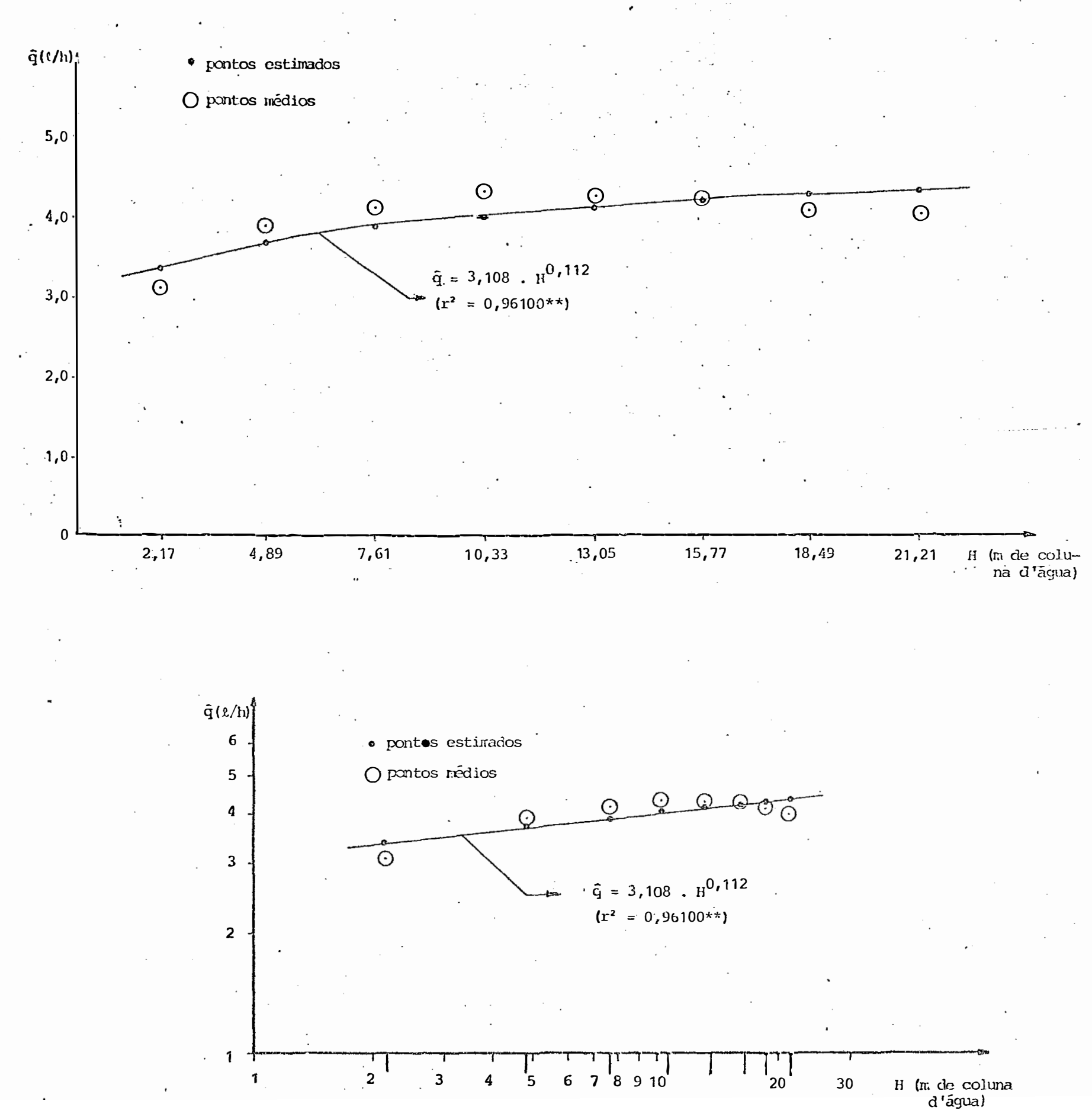

Figura 12 - Representação gráfica da curva obtida para a equação geométrica determinada para o goteja dor IRTEC-2, em escala decimal e logarítmica. 


\section{1.}
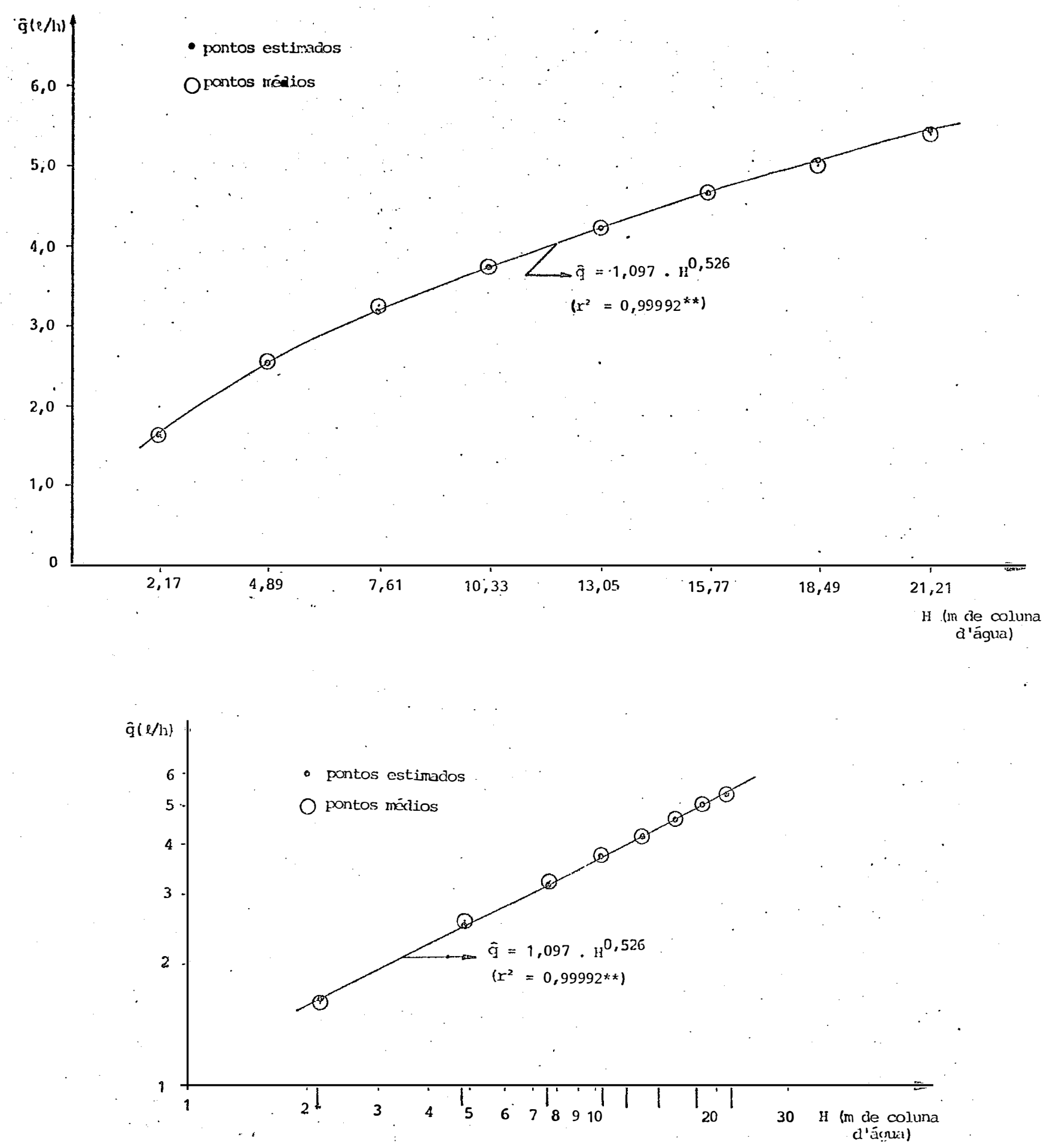

Figura 13 - Representação gräfica da curva obtida para a equação geométrica determinada para o goteja dor DANTAS, em escala decimal e logarítmica。 
Devido a este coeficiente ser alto, o que significa que cerca de $96^{\circ}$ da variação ocorrida foi explicada por esta equação, confere aos valores obtidos da vazão média dos gotejadores testados, para cadí pressão aplicada, terem um ajustamento adequado à equação determinada.

\section{Gotejador DANTAS:}

Para o gotejador DANTAS, a regressão foi significativa ao nive1 de $1 \%$, para o teste F, obtendo-se um coeficiente de determinação $\left(\mathrm{r}^{2}\right)$ igual a 0,99992**. Devido a este coeficiente ser bastante elevado, o que significa que quäse toda a variação ocorrida foi explicada por esta equação, confere aos valores obtidos da vazão mẻdia dos gotejadores testados, para cada pressão aplicada, terem um ötimo ajusćamento em relação à equa-ção determinada.

A equação caracterîstica de descarga-pres são para o gotejador DANTAS, encontrada por lOLIVEIRA (1978), $\hat{q}=1,329 . \mathrm{H}^{0}, 513$, com $\mathrm{r}^{2}=0,99960 * *$, esteve bem prôxima à equação determinada neste trabalho, o que confere uma certa validade a esta equação como sendo representativa da função de fluxo do referido gotejador. Também,com relação ao expoente de descar ga $\underline{x}$, que caracteriza o regime de fluxo no gotejador,os 
valores encontrados estiveram bem próximos, confirmando que o fluxo de água passando pelo interior do gotejador encontra-se no regime turbulento。

Os resultados da análise de regressão pa ra as equações geométricas determinadas, podem ser vistos nos Quadros 41,42 e 43 do Apêndice 4, para os três gotejadores experimentados: IRTEC-1, IRTEC-2 e DANTAS, respectivamente。

\section{3 .3 - Regress̃̃o poIinomial}

A" anālise da variância deverá refletir a dependência entre os tratamentos, justificando a existência de uma correspondência funcional (chamada equação de regressão) que ligue os valores dos tratamentos (pressões aplicadas) aos dados analisados (vazão do gotejador).

Para estabelecer-se esta equação de regressão, que melhor ajustasse os valores de vazão dos gotejadores testados, em função da pressão aplicada sobre os mesmos, usou-se o método dos polinômios ortogonais, calculando-se os coeficientes correspondentes a todos os componentes, do linear até o ủltimo significativo, mesmo que neste intervalo houvesse algum componen te não significativo。 
Os resultados desisa anảlise da variância podem ser vistos nos Quadros 44, 45 e 46 do Apêndice 4, para os três gotejadores experimentados: IRTEC-1, IRTEC-2 e DANTAS, respectivamente.

\section{$\underline{\text { Gotejador IRTEC-1: }}$}

- Para o gotejador IRTEC-I, a anâlise reve lou que apenas o componente de 2 g grau foi significativo ao nível de $5 \%$, com a aplicação do teste F.

Para a obtenção da equação de regressão, calcularam-se os coeficientes para interpolação de poli nômios ortogonais, correspondentes a todos os componentes, do linear até o quadrätico, ültimo significativo.

A equação de regressão do 20 grau determinada, para o gotejador IRTEC-1, foi a seguinte:

$$
\hat{\mathrm{q}}=3,105+0,131 \cdot \mathrm{H}-6,621 \cdot 10^{-3} \mathrm{H}^{2},
$$

em que:

$$
\begin{aligned}
\hat{\mathrm{q}}= & \text { vazão média estimada do gotejador, em } 1 / \mathrm{h} ; \\
\mathrm{H}= & \text { pressão na entrada do gotejador, em m de co } \\
& \text { luna d'âgua. }
\end{aligned}
$$


O Coeficiente de Determinação $\left(r^{2}\right)$ da equação de regressão quadrätica, para o gotejador IRTEC1, foi igual a 0,83757 . Devido a este coeficiente ser relativamente alto, o que significa que cerca de $84 \%$ da variação ocorrida foi explicada por esta equação, os va lores obtidos da vazão média dos gotejadores testados, para cada pressão aplicada, tiveram um bom : ajustamento em relação à equação determinada.

A representação gráfica da equação

encontra-se na Figura 14.

Gotejador JRTEC-2:

Para o microgotejador IRTEC-2, a anälise revelou que o teste $F$ foi significativo ao nivel de $1_{0}^{\circ}$ para os componentes de $19,2 \%$ e $3 \%$ graus.

Para a obtenção da equação de regressão, calcularam-se os coeficientes para interpolação de poli nômios ortogonais, correspondentes a todos os componentes, do linear atê o cúbico, último significativo.

A equação de regressão do 3 ! grau deter minada para o microgotejador IRTEC-2, foi a seguinte:

$$
\begin{aligned}
\hat{\mathrm{q}}=2,273+0,456 \mathrm{H} & -3,148 \cdot 10^{-2} \mathrm{H}^{2}+ \\
& +6,595 \cdot 10^{-4} \mathrm{H}^{3},
\end{aligned}
$$

em que: 
116.

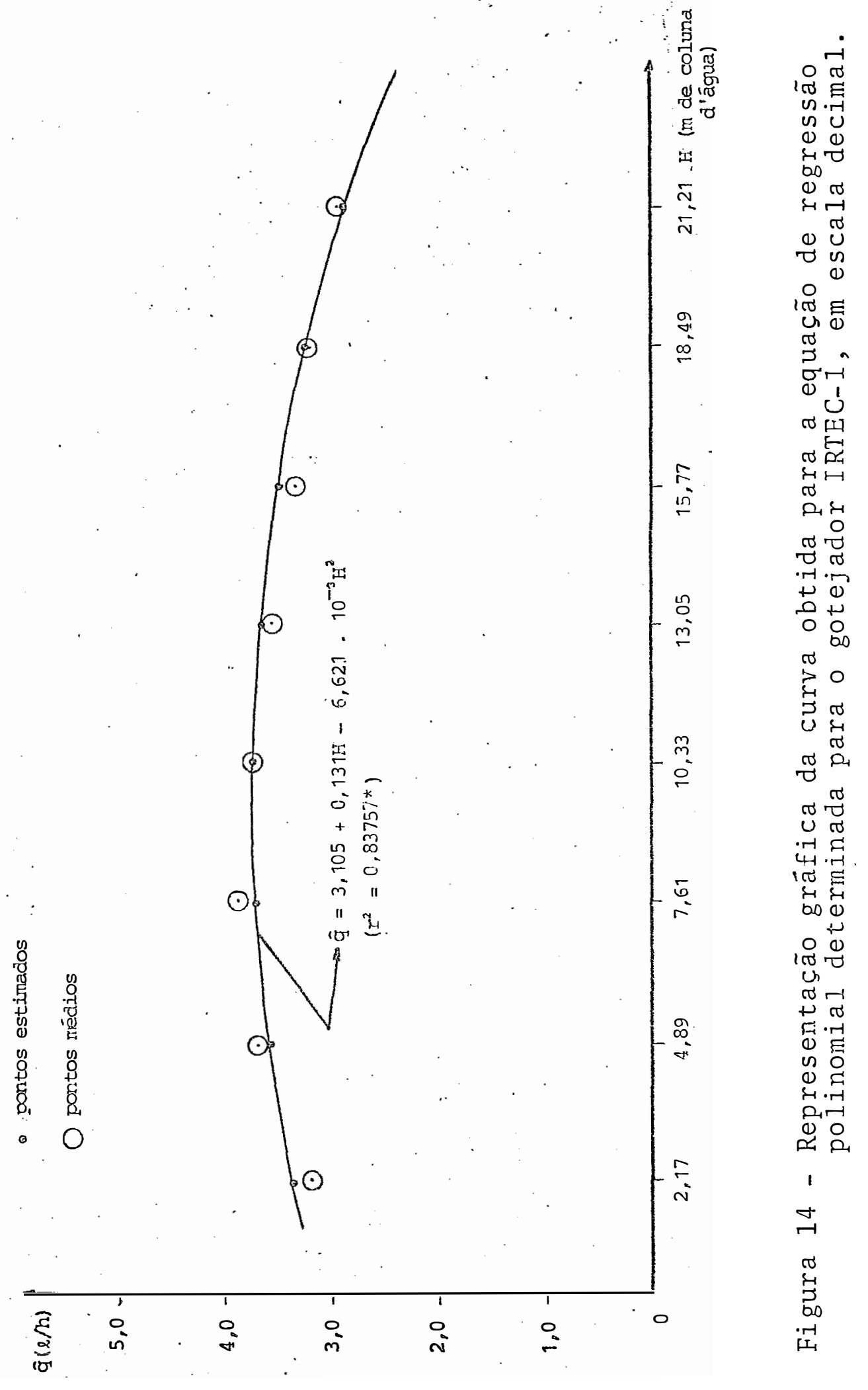




$$
\begin{aligned}
\hat{q}= & \text { vazão média estimada do gotejador, em } 1 / \mathrm{h} ; \\
\mathrm{H}= & \text { pressão na entrada do gotejador, em m de colu- } \\
& \text { na d'água. }
\end{aligned}
$$

0 Coeficiente de Determinação $\left(r^{2}\right)$ da equação de regressão cúbica, para o microgotejador IRTEC2, foi igual a $0,98789 * *$. Devido a este coeficiente ser elevado, o que significa que cerca de 99\% da variação ocorrida foi explicada por esta equação, os valores obtidos da vazão média dos gotejadores testados, para cada pressão aplicada, tiveram um ótimo ajustamento em re lação à equação äeterminada.

$$
\text { A representação gráfica da equação }
$$
encontra-se na Figura 15.

FARIA (1981), estudando as caracteristicas hidrâuIicas do microgotejador IRTEC, submeteu-os a diferentes pressões e sob a mesma temperatura da āgua $\left(23^{\circ} \mathrm{C}\right)$, obtendo valores correspondentes de vazão versus pressão, com os quais estimou a seguinte equação de regressão do 4 : grau:

$$
\begin{aligned}
\hat{\mathrm{q}}=-0,05306 & +1,32523 \mathrm{H}-0,13562 \mathrm{H}^{2}+ \\
& +0,00583 \mathrm{H}^{3}-0,00009 \mathrm{H}^{4},
\end{aligned}
$$

em que: 
118.

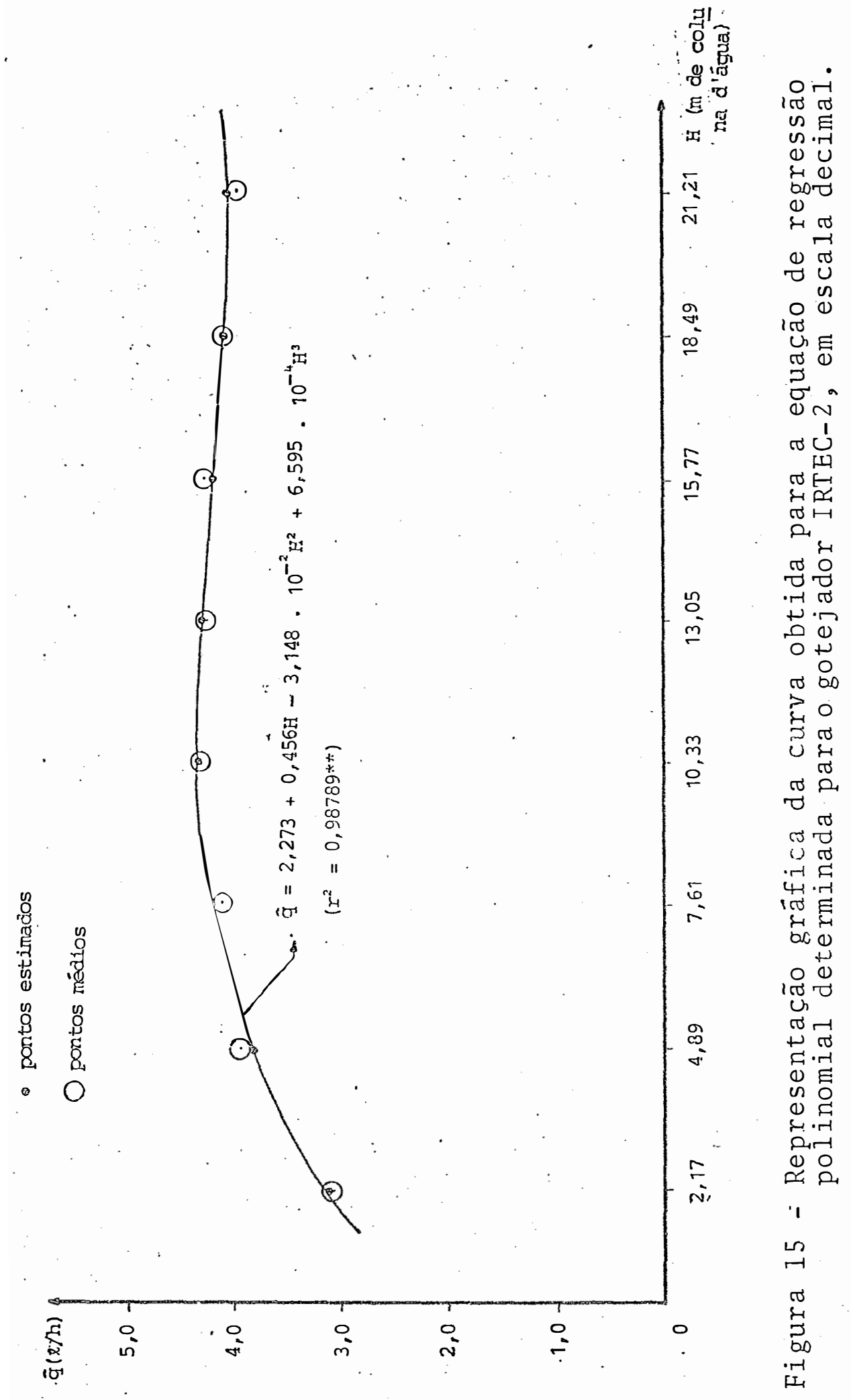




$$
\begin{aligned}
\hat{\mathrm{q}}= & \text { vazão estimada do microgotejador, em } 1 / \mathrm{h} ; \\
\mathrm{H}= & \text { pressão na entrada do microgotejador, em m } \\
& \text { de coluna d'água. }
\end{aligned}
$$

o Coeficiente de Determinação $\left(r^{2}\right)$ desta equação foi 0,9998 e o teste F significativo ao nível de $1^{\circ}$ de probabilidade.

Como mostra a sua análise de variância e regressão polinomial, apenas cerca de $1,6 \%$ da variação explicada é devida ao efeito do componente de 49 grau,o que confere à equação de regressão do 39 grau, encontra da neste trabalho", como sendo representativa da estimativa de vazão, em função da pressão aplicada, para o mi crogotejador IRTEC.

\section{Gotejador DANTAS:}

Para o gotejador DANTAS, a anālise revelou que o teste $F$ foi significativo ao nível de $1 \%$, para os componentes de $19,2 \%, 39,49$ e 59 graus.

Para a obtenção da equação de regressão, calcularam-se os coeficientes para interpolação de poli nômios ortogonais, correspondentes a todos os componentes, do linear até o de 59 grau, o último significativo.

- A equação de regressão do 59 grau determinada para o gotejador DANTAS, foi a seguinte: 


$$
\begin{aligned}
\hat{\mathrm{q}}=0,403 & +0,693 \mathrm{H}-0,073 \mathrm{H}^{2}+ \\
& +5,523 \cdot 10^{-3} \mathrm{H}^{3}- \\
& -2,128 \cdot 10^{-4} \mathrm{H}^{4}+ \\
& +3,197 \cdot 10^{-6} \mathrm{H}^{5},
\end{aligned}
$$

em que:

$$
\begin{aligned}
\hat{q}= & \text { vazão mêdia estimada do gotejador, em } 1 / \mathrm{h} ; \\
\mathrm{H}= & \text { pressão na entrada do gotejador, em m de co } \\
& \text { luna d'ägua. }
\end{aligned}
$$

o coeficiente de determinação $\left(r^{2}\right)$ da equa ção de regressão de 5 ! grau, para o gotejador DANTAS, foi igual a 0,99999**. Devido a este coeficiente se: elevadíssimo, o que significa que quase toda a variação ocorrida foi explicada por esta equação, os valores obtidos da vazão mêdia dos gotejadores testados, para cada pressão aplicada, tiveram um perfeito ajustamento em relação à equação determinada.

A representação gráfica da equação acima, encontra-se na Figura 16 . 


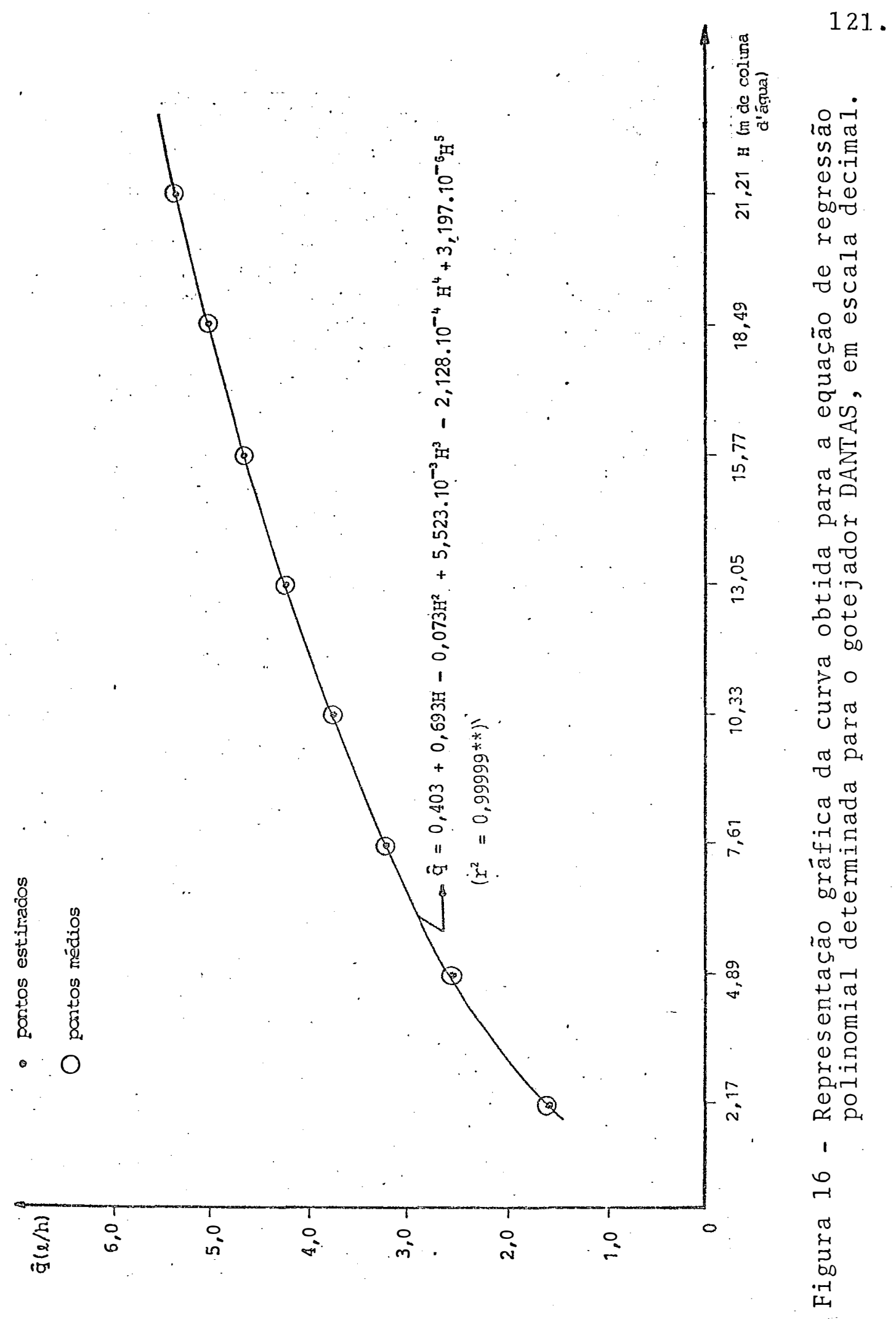




\subsection{4 - Análise final}

\section{Gotejador IRTEC-1:}

A equação de fluxo para o gotejador IRTEC-1, representada pela equação geométrica, do tipo $\mathrm{q}=\mathrm{K}_{\mathrm{d}} \cdot \mathrm{H}^{\mathrm{X}}$, teve um coeficiente de determinação $\left(\mathrm{r}^{2}\right)$ igual a $0,90429^{* *}$, enquanto que para a equação de re- . gressão polinomial foi encontrada uma equação do 2 g grau, tendo um coeficiente de determinação $\left(\mathrm{r}^{2}\right)$ igual a $0,83757^{*}$. Assim, como a equação geométrica (27) teve um coeficien te de determinação $\left(r^{2}\right)$ maior do que o da equação de re gressão polinomial (30), e com uma significância ao nível de $1 \%$, pode-se dizer que aquela equação ajustou melhor os valores da vazão média do gotejador IRTEC-1, em função da pressão aplicada.

Analisando-se os valores de vazão média dos gotejadores, em ordem crescente de pressão aplicada, verifica-se que a equação geométrica propicia um melhor ajustamento a esses valores, conforme mostra a Figura 11. Porém, se observarmos o Quadro 10, verificaremos a 1 tos valores para o erro padrão da média $\left[s\left(\bar{q}_{m}\right)\right]$ da vazão dos gotejadores, em todas as pressões aplicadas, e principalmente, altos valores do coeficiente de variação em cada pressão aplicada, onde evidencia uma grande 
variabilidade de vazão dentro de uma mesma pressão apli cada, o que vem confirmar os altos valores do Coeficien te de Variação de Fabricação do gotejador IRTEC-1, obti dos durante os testes de Uniformidade de Vazão, devido às diferenças existentes entre os gotejadores, decorren tes do processo de fabricação.

Quadro 10 - Valores do erro padrão da mẻdia e do coeficiente de variação da vazão média dos gotejadores IRTEC-1, para cada diferente pressão aplicada.

\begin{tabular}{|c|c|c|c|c|c|c|c|c|}
\hline \multirow{2}{*}{$\begin{array}{l}\text { VAZTO } \\
(1 / \mathrm{h})\end{array}$} & \multicolumn{8}{|c|}{ PRESSÃO (m de coluna d'água) } \\
\hline & 2,17 & 4,89 & 7,61 & 10,33 & 13,05 & 15,77 & 18,49 & 21,21 \\
\hline$\overline{\mathrm{q}}_{\mathrm{m}}$ & 3,20 & 3,71 & 3,91 & 3,75 & 3,58 & 3,37 & 3,28 & 2,97 \\
\hline$s\left(\bar{q}_{m}\right)$ & 0,35 & 0,28 & 0,34 & 0,29 & 0,21 & 0,32 & 0,54 & 0,53 \\
\hline C.V. & $34,2 \%$ & $23,8^{\circ}$ & $27,7 \%$ & $24,4 \%$ & $18,8 \%$ & $30,0^{\circ}$ & $51,6 \%$ & $56,9 \%$ \\
\hline
\end{tabular}

sendo:

$$
\begin{aligned}
\overline{\mathrm{q}}_{\mathrm{m}}= & \text { vazão média referente aos valores médios dos } \\
& \text { dados observados de vazão dos gotejadores, em } \\
& 1 / \mathrm{h} ; \\
\mathrm{s}\left(\overline{\mathrm{q}}_{\mathrm{m}}\right)= & \text { erro padrão da média da vazão dos gotejadores, } \\
& \text { para cada pressão aplicada, em } 1 / \mathrm{h} ; \\
\mathrm{C} . \mathrm{V} \cdot= & \text { coeficiente de variação da vazão média dos } \\
& \text { gotejadores, para cada pressão aplicada, em } \\
& \text { porcentagem. }
\end{aligned}
$$




\section{Gotejador IRTEC-2:}

A equação de fluxo para o microgotejador IRTEC-2, representada pela equação geométrica, do tipo $\mathrm{q}=\mathrm{K}_{\mathrm{d}} \cdot \mathrm{H}^{\mathrm{X}}$, teve um coeficiente de determinação $\left(\mathrm{r}^{2}\right)$ igual a 0,96100**, enquanto que para a equação de regressão polinomial foi encontrada uma equação do 3 : grau, tendo um coeficiente de determinação $\left(r^{2}\right)$ igual a,0,98789**. Assim, como a equação de regressão polimial (31) teve um coeficiente de determinação $\left(r^{2}\right)$ maior do que o da equação geométrica (28), e com uma significância ao nível de $1 \%$ para ambas, pode-se dizer que aque la equação se ajustou melhor aos valores da vazão média do microgotejador IRTEC-2, em função da pressão aplicada. Analisando-se os valores de vazão média dos gotejadores, em ordem crescente de pressão aplicada, verifica-se que a equação de regressão cübica propicia um bom ajustamento a esses valores, conforme mostra a Figura 15. Porém, observando o Quadro 11, verificaremos, tambêm, altos valores para o erro padrão da média $\left[s\left(\bar{q}_{m}\right)\right]$ da vazão dos gotejadores, em todas as pressões, aplicadas, e principalmente, altos valores do Coeficiente de Variação em cada pressão aplicada, embora um pouco meno res em relação ao gotejador IRTEC-1, mas mesmo assim evidenciando uma grande variabilidade de vazão dentro de 
uma mesma pressão aplicada, o que vem confirmar os altos valores do Coeficiente de Variação de Fabricação do microgotejador IRTEC-2, obtidos durante os testes de Uniformidade de Vazão, devido às diferenças existentes entre os gotejadores, decorrentes do processo de fabricação .

Quadro 11 - Valores do erro padrão da média e do coeficiente de variação da vazão média dos gotejadores IRTEC-2, para cada diferente pressão aplicada.

\begin{tabular}{|c|c|c|c|c|c|c|c|c|}
\hline \multirow{2}{*}{$\begin{array}{l}\text { VAZ ̃OO } \\
(1 / \mathrm{h})\end{array}$} & \multicolumn{8}{|c|}{ le coluna d'ägua) } \\
\hline & 2,17 & 4,89 & 7,61 & 10,33 & 13,05 & 15,77 & 18,49 & 21,21 \\
\hline$\overline{\mathrm{q}}_{\mathrm{m}}$ & 3,09 & 3,92 & 4,16 & 4,34 & 4,30 & 4,27 & 4,12 & 4,07 \\
\hline $\mathrm{s}\left(\overline{\mathrm{q}}_{\mathrm{m}}\right)$ & 0,19 & 0,25 & 0,25 & 0,28 & 0,30 & 0,34 & 0,30 & 0,31 \\
\hline C.V. & $19,0 \%$ & $19,9 \%$ & $19,3 \%$ & $20,3 \%$ & $22,2 \%$ & $25,5 \%$ & $23,2 \%$ & $23,9 \%$ \\
\hline
\end{tabular}

Gotejador DANTAS:

A equação de fluxo para o gotejador DANTAS, representada pela equação geométrica, do tipo $q=$ $=K_{d} \cdot H^{X}$, teve um coeficiente de determinação $\left(r^{2}\right)$ igual a 0,99992**, enquanto que para a equação de regres são polinomial foi encontrada uma equação do 5 o grau co mo a que melhor se ajustou aos valores da vazão mëdia 
do gotejador DANTAS, em função da pressão aplicada, tẹn do um coeficiente de determinação $\left(r^{2}\right)$ igual a 0,99999**. Analisando-se os valores do coeficiente de determinação $\left(r^{2}\right)$ das duas equações (29) e (33), ambas tiveram valores elevadíssimos, onde praticamente to da a variação ocorrida foi explicada pelas equações.Mas, como a variação explicada pela regressão linear na análise para Interpolação de Polinômios Ortogonais, representa cerca de $97^{\circ}$ da variação total ocorrida, podemos considerar que a equação de regressão linear, do tipo $\mathrm{q}=\mathrm{K}_{\mathrm{d}} \cdot \mathrm{H}^{\mathrm{X}}$, propicia um ótimo ajustamento aos valores de vazão média dos gotejadores, conforme ilustra a Fig $\underline{u}$ ra 13, e vai de encontro à equação obtida por OLIVEIRA (1978)。

Observando-se o Quadro 12, verificam-se báixos valores para o erro padrão da mẻdia $\left[s\left(\vec{q}_{m}\right)\right]$ da vazão dos gotejadores, em todas as pressões aplicadas, e principalmente, baixos valores do Coeficiente de.Variação em cada pressão aplicada, evidenciando uma pequena dispersão dos valores de vazão dentro de uma mesma pres são aplicada, o que vem confirmar os baixos valores do Coeficiente de Variação de Fabricação do gotejador DANTAS, obtidos durante os testes de Uniformidade de Vazão. 
Quadro 12 - Valores do erro padrão da média e do coeficiente de variação da vazão média dos gotejadores DANTAS, para cada diferente pressão aplicada.

\begin{tabular}{|c|c|c|c|c|c|c|c|c|}
\hline \multirow{2}{*}{$\begin{array}{l}\text { VAZT̃O } \\
(1 / \mathrm{h})\end{array}$} & \multicolumn{8}{|c|}{ PRESSÄO ( $m$ de coluna d'água) } \\
\hline & 2,17 & 4,89 & 7,61 & 10,33 & 13,05 & 15,77 & 18,49 & 21,21 \\
\hline $\bar{q}_{m}$ & 1,62 & 2,57 & 3,23 & 3,76 & 4,25 & 4,68 & $\cdot 5,05$ & 5,41 \\
\hline$s\left(\bar{q}_{m}\right)$ & 0,008 & 0,004 & 0,006 & 0,008 & 0,008 & 0,009 & 0,010 & 0,019 \\
\hline C.V. & $1,48^{\circ}$ & $0,47^{\circ}$ & $0,56^{\circ}$ & $0,64 \%$ & $0,56^{\circ}$ & $0,60 \%$ & $0,63 \%$ & $1,11 \%$ \\
\hline
\end{tabular}

Portanto, a equação de regressão determi nada, do tipo $\mathrm{q}=\mathrm{K}_{\mathrm{d}} \cdot \mathrm{H}_{\mathrm{x}}$, é a que vem melhor repre sentar a realidade dos valores encontrados (Quadro 40 do Apêndice 3) durante o teste realizado para Determinação da Equação Característica de Descarga-Pressão do goteja dor DANTAS. 


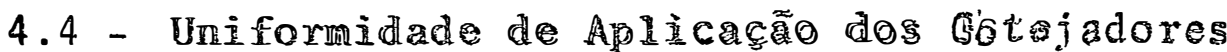

4.4.1 - Uniformidade de Emissão dos gotejadores na 1 inha lateral

Após a elaboração do programa de computa dor, introduziu-se, para cada respectivo gotejador, a equação característica de descarga-pressão determinada, juntamente com o seu Coeficiente de Variação de Fabrica ção global $\left(\mathrm{CV}_{\mathrm{fg}}\right)$, e a seguir forneceram-se os valores da razão de perda de carga (RPC), para cada pressão de serviço (Hs) adotadä.

Com a introdução desses elementos, construiram-se as tabelas, imprimindo-se os valores da razão de descarga máxima (RDMX), da razão de descarga mínima (RDM), da razão de perđa (RP), da razão de vazão $(\dot{R} V)$, da Uniformidade de Emissão (UH), da Uníformidade de Emissão Absoluta (UEa) e da Área Mais Molhada (AMḾ), para cada nível de pressão de serviço (Hs) adotado.

As tabelas de Uniformidade de Emissão são apresentadas nos Quadros 13, 14 e 15, respectivamente, para os gotejadores DANTAS, IRTEC-1 e IRTEC-2.

Com as tabelas obtidas, procedeu-se a uma análise dos resultados encontrados, para cada tipo de gotejador estudado. 

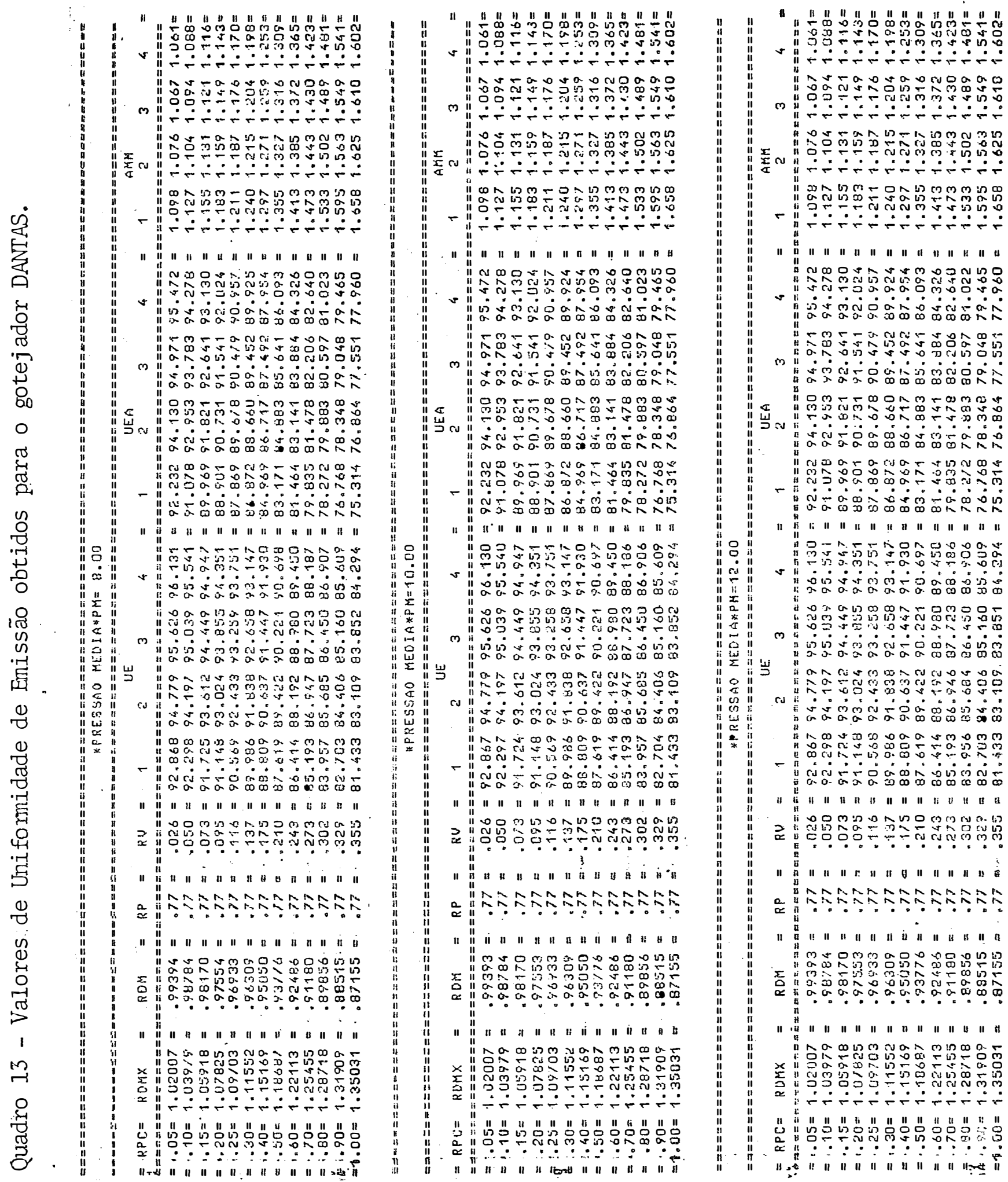

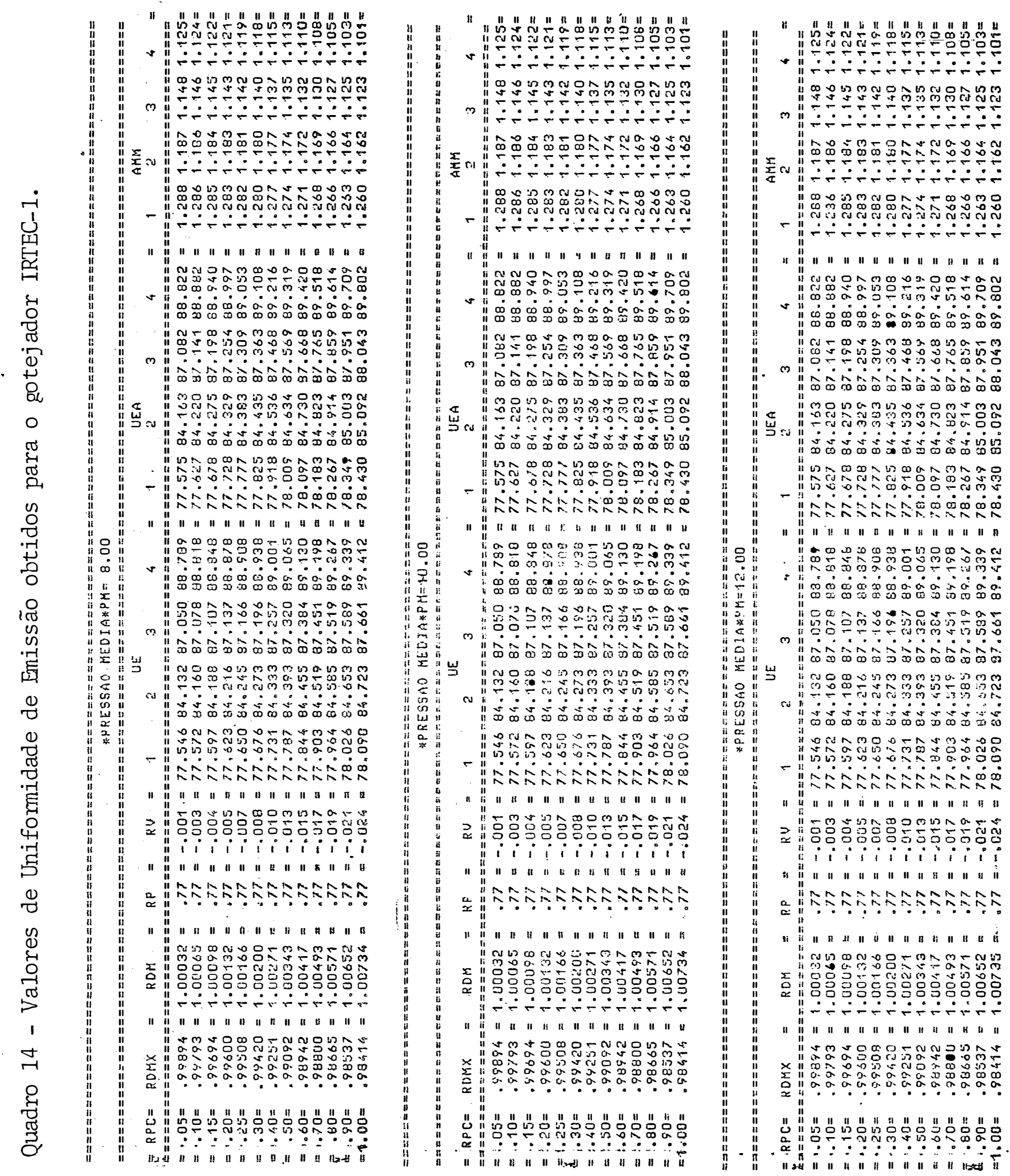

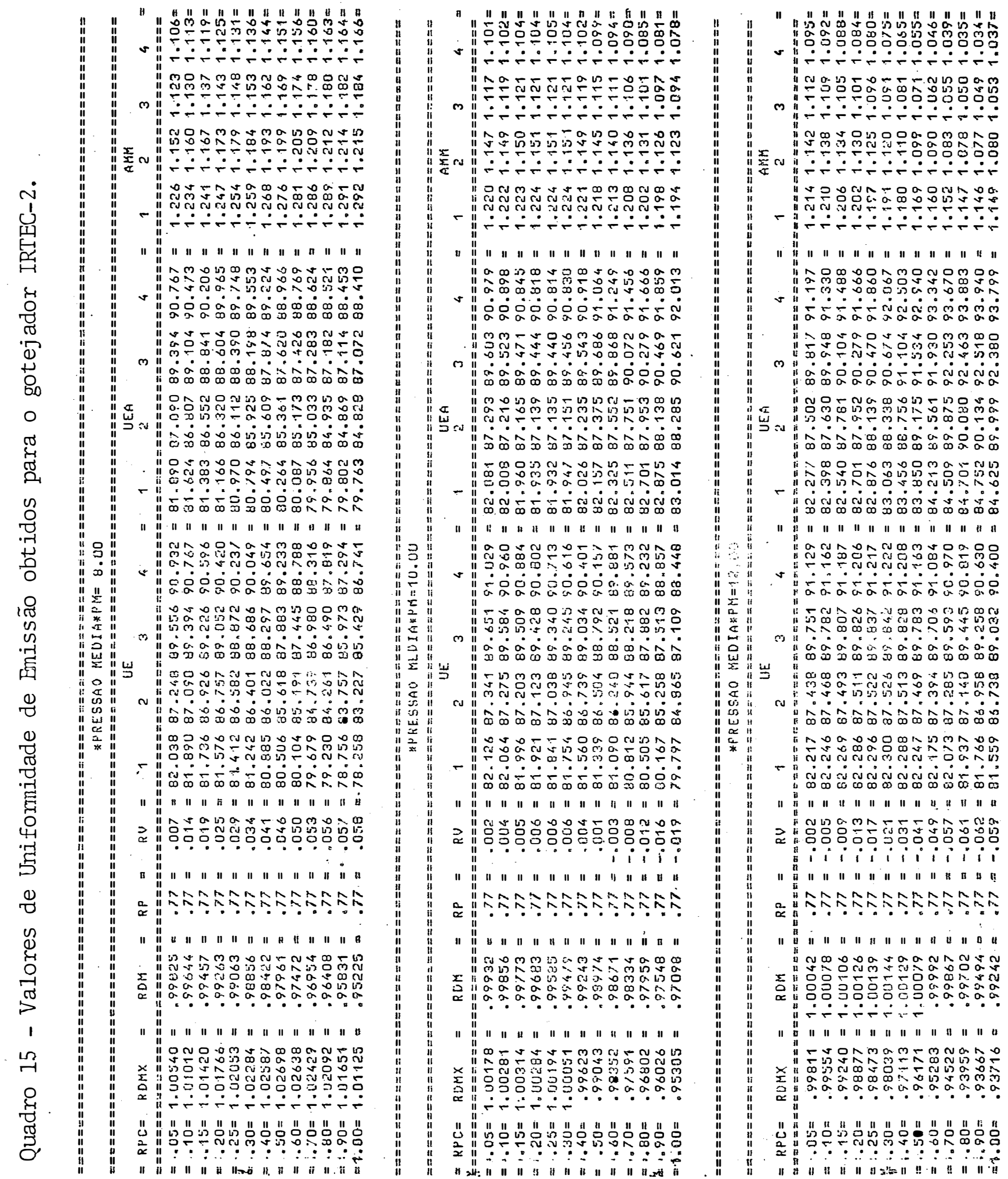
Gotejador DANTAS:

Para o gotejador DANTAS, utilizou-se a equação geométrica (29):

$$
\hat{q}=1,097 \cdot H^{0,526,},
$$

e o Coeficiente de Variação de Fabricação global ( $\left.\mathrm{CV}_{f g}\right)$ igual a 0,0517 .

Sendo o expoente de descarga da equação geomêtrica $(0,526)$ igual ao coeficiente angular desta equação em papel dilogarítmico, resultou que a razão de descarga máxima (RDMX) e a razão de descarga mínima(RDM) tiveram valores praticamente iguais para cada valor da razão de perda de carga (RPC) nos três níveis de pressão de serviço (Hs) adotados, com exceção de apenas alguns valores que tiveram uma diferença entre si de uma unidade apenas na quinta casa decimal.

Consequentemente, os valores dos demais parâmetros constantes da tabela foram iguais, com exceção para uns poucos valores, onde houve uma diferença entre si de uma unidade apenas na terceira casa decimal. Portanto, pode-se concluir que os valores da Uniformidade de Emissão, Uniformidade de Emissão Absoluta e Ārea Mais Molhada são praticamente os mesmos para cada valor da razão de perda de carga, em todos os três níveis de pressão de serviço adotados. 
A aplicação do teste de Lilliefors reve lou uma não aderência dos dados de vazão dos gotejadores amostrados à distribuição normal proposta, nos três testes de Uniformidade de Vazão realizados com o goteja dor DANTAS.

SOLOMON (1977), conforme relatado no item 2.3.2, considerou que o emprego para os quais essas dis tribuições serão colocadas, provavelmente não asseguraria o uso de uma distribuição mais complexa, mesmo ise ela fosse mais representativa do que a distribuição normal. Sendo assim, seguimos esta argumentação para a elabora ção da tabela de Uniformidade de Emissão do gotejador DANTAS, jả que as fórmulas empregadas no seu cảlculo ba seiam-se em definições estatísticas fundamentadas numa variāvel ao acaso distribuída normalmente.

$\mathrm{Na}$ análise seguiremos a recomendação fei ta por KELLER e KARMELI (1974), de que é desejäve1 que a Uniformidade de Emissão do sistema seja 94: ou mais,e que em nenhum caso a Uniformidade de Emissão do projeto deveria estar abaixo de $90 \%$

Assim, adotando-se este critério, verif camos que para 1 (um) gotejador por planta podemos permitir uma razão de perda de carga (RPC) até 0,30 , onde ocorreria uma variação de vazão de $13,7^{\circ}$ entre a vazão máxima e mínima na linha 1ateral. A Uniformidade de Em.ís 
são Absoluta (UEa) seria de $86,87^{\circ}$, e a Ārea Ma is Molha da (AMM) receberia $24 \%$ a mais de ägua, em relação à 1âmina média aplicada. Também, notamos que com um gotejador por planta não será atingida a Uniformidade de Emis são (UE) desejada, de $94 \%$, mesmo adotando-se uma razão de perda da carga (RPC) de 0,05, que proporcionaria uma uniformidade mảxima de $92,87^{\circ}$.

Para 2 (dois) gotejadores por planta, uma Uniformidade de Emissão de $90 \%$ poderia ser atingida per mitindo-se uma razão de perda de carga (RPC) atê 0,40, onde ocorreria uma variação de vazão de $17,5 \%$ entre a vazão máxima e mínima na linha lateral. A Uniformidade de Emissão Absoluta (UEa) seria de 86,72\% e a Area lía is Molhada (AMM) receberia $27,1 \%$ a mais de ägua, em relação à 1âmina mẻdia aplicada. A Uniformidade de Emissão désejada de $94 \%$ seria atingida adotando-se uma razão de perda de carga (RPC) abaixo de 0,10 .

Para 3 (três) e 4 (quatro) gotejadores por planta, uma Uniformidade de Emissão de $90 \%$ poderia ser atingida permitindo-se uma razão de perda de carga de até 0,50 , onde ocorreria uma variação de vazão de $21 \%$ en tre a vazão máxima e mínima na linha lateral. A Uniformidade de Emissão Absoluta (UEa) seria de 85,64\% e 86,09\%, e a Ārea Mais Molhada (AMM) receberia 31,6\% e 30,9\% a 
mais de água, em relação à lâmina média aplicada, respectivamente para 3 e 4 gotejadores por planta. A Uniformidade de Emissão desejada de $94 \%$ seria atingida ado tando-se uma razão de perda de carga (RPC) abaixo de 0,15 , para três gotejadores por planta, e abaixo de 0,20 para quatro gotejadores por planta.

\section{Gotejador IRTEC-1:}

Para o gotejador IRTEC-1 a aplicação do teste de Lilliefors revelou que os dados de vazão do go. tejador podem ser estudados através da distribuição nor mal.

Assim, utilizou-se a equação geométrica (27):

$$
\hat{q}=3,680 \cdot \mathrm{H}^{-0,028},
$$

e o Coeficiente de Variação de Fabricação global ( $\mathrm{CV}_{\text {fg }}$ ) igual a 0,1770, para a elaboração da tabela de Uniformi dade de Emissão do respectivo gotejador.

Como o expoente de descarga da equação

geométrica obtida para o gotejador IRTEC-1 foi igual a $-0,028$, portanto um valor negativo, resultou que a vazão do gotejador no início da linha lateral foi menor que a vazão média do gotejador, e a vazão do gotejador 
no final da linha lateral foi maior do que a vazão mêdia.do gotejador. Assim, os valores encontrados para a razão de descarga máxima (RDMX) foram menores do que 1 e os valores encontrados para a razão de descarga mínima (RDM) foram maiores do que 1 , resultando valores negativos para a razão de vazão (RV).

- Sendo o expoente de descarga da equação geométrica $(-0,028)$ igual ao coeficiente angular desta equação em papel dilogarítmico, resultou que a razão de descarga máxima (RDMX) e a razão de descarga mínima(RDM) tiveram todos os seus valores iguais, para cada valor da razão de perda de carga (RPC) nos três nỉveis de pres são de serviço (Hs) adotados, com exceção de apenas um valor que teve uma diferença entre si de uma unidade apenas na quinta casa decimal. Consequentemente, os vaío res dos demais parâmetros constantes da tabela foram iguais.

Portanto, pode-se concluir que os valores da Uniformidade de Emissão (UE), Uniformidade de Emissão Absoluta (UEa) e Area Mais Molhada (AMM) são os mesmos, para cada valor da razão de perda de carga(RPC), em todos os três níveis de pressão de serviço (Hs) adotados. 
$\mathrm{Na}$ análise dos resultados obtidos, verificou-se que até com 4 (quatro) gotejadores por planta não será atingida a Uniformidade de Emissão de $90 \%$ para este gotejador, com qualquer valor da razão da perda de carga. Para 1 (hum) gotejador por planta a uniformidade de emissão estará ao redor de $77 \%$ para todos os valores da razão de perda de carga; para 2 (dois) gotejadores por planta a uniformidade de emissão estará ao redor de $84^{\circ}$ para todos os valores da razão de perda de carga;pa ra 3 (três) gotejadores por planta a uniformidade de emissão estará ao redor de $87 \%$ para todos os valores da razão de perda de carga; e para 4 (quatro) gotejadores por planta a uniformidade de emissão estarā prỏxima de $89 \%$, para todos os valores da razão de perda de carga. Para a Uniformidade de Emissão Absoluta (UEa) foram encontrados valores praticamente iguais aos encontrados para a Uniformidade de Emissão (UE), estando ao redor de $78 \%, 84 \%, 87 \%$ e $89 \%$, respectivamente, com 1 (um), 2(dois), 3 (três) e 4 (quatro) gotejadores por planta.

A Ārea Mais Molhada (AMM) variou de $28,8 \%$ a $26 \%$ do menor para o maior valor da razão de perda de carga, com 1 (um) gotejador por planta. Com 2 (dois) go. tejadores por planta, variou de $18,7 \%: a$ : $16 ; 2 \%$, do menor 
para o maior valor da razão de perda de carga. Com 3 (três) gotejadores por planta, variou de 14,8\% a 12,3\%, do menor para o maior valor da razão de perda de carga. E com 4 (quatro) gotejadores por planta, variou de $12,5 \%$ a $10,1 \%$ do menor para o maior valor da razão de perdade carga.

Gotejador IRTEC-2:

Para o gotejador IRTEC-2, a aplicação do teste de Lilliefors revelou que os dados de vazão do go tejador podem ser estudados através da distribuição nor mal.

Assim, utilizou-se a equação de' regressão cübica (31):

$$
\begin{aligned}
\hat{\mathrm{q}}=2,273 & +4,562 \cdot 10^{-1} \mathrm{H}-3,148 \cdot 10^{-2} \mathrm{H}^{2}+ \\
& +6,595 \cdot 10^{-4} \mathrm{H}^{3},
\end{aligned}
$$

e o Coeficiente de Variação de Fabricação global ( $\mathrm{CV}_{f g}$ ) igual a 0,1403, para a elaboração da tabela de Uniformi dade de Emissão do respectivo gotejador.

Com a utilização da equação de regressão polinomial do 39 grau, obtida para o gotejador IRTEC-2, resultaram valores normais tanto para a razão de descar ga máxima (RDMX) como para a razão de descarga mínima 
(RDM), isto é, a vazão do gotejador no início da linha lateral foi maior que a vazão média do gotejador e a va zão do gotejador no final da linha lateral foi menorque a vazão média do gotejador, isto para o nível de pressão de serviço (Hs) adotado de $8,0 \mathrm{~m}$ de coluna d'água.

Já para a pressão de serviço (Hs) de 10,0 $\mathrm{m}$ de coluna d'água, resultaram valores normais para uma razão de perda de carga (RPC) de até 0,30 , e para razões de perda de carga (RPC's) acima de 0,40, resultaram valores abaixo de 1 , tanto para a razão de descarga máxima (RDMX), como para a razão de descarga mínima(RDM).

Para a pressão de serviço (Hs) de 12,0 m de coluna d'água, a vazão no início da linha lateral foi menor que a vazão média do gotejador e a vazão no final da linha lateral foi maior que a vazão média do gotejador, resultando valores menores do que 1 para a razão de descarga máxima (RDMX) e valores maiores do que 1 para a razão de descarga mínima (RDM), isto para valo res da razão de perda de carga (RPC) abaixo de 0,50. Já para valores da razão de perda de carga (RPC) acima de 0,60 , resultaram valores menores do que 1 , tanto para a razão de descarga máxima (RDMX), como para a razão de des carga mínima (RDM)。

Isto posto, verificamos que tanto a razão de descarga máxima (RDMX), como a razão de descarga 
mínima (RDM) são diferentes para cada valor da razão de perda de carga (RPC), em todos os trēs níveis de pressão de serviço (Hs) adotados.

Portanto, pode-se concluir que tambëm os valores da Uniformidade de Emissão (UE), Uniformidade de Emissão Absoluta (UEa) e Ârea Mais Molhada (AMM) são di ferentes para cada valor da razão de perda de carga (RPC), em todos os três níveis de pressão de: serviço (Hs) adotados.

$\mathrm{Na}$ análise dos resultados obtidos para a pressão de serviço adotada de $8,00 \mathrm{~m}$ de coluna d'água, verificou-se que a Uniformidade de Emissão de $90 \%$ somen te será atingida com a utilização de 4 (quatro) gotejadores por planta, para razões de perda de carga (RPC's) abaixo de 0,30 .

0 intervalo de variação dos valores da Uniformidade de Emissão (UE), Uniformidade ¿de Emissão Absoluta (UEa) e Ârea Mais Molhada (AMM), para a pressão de serviço (Hs) de $8,0 \mathrm{~m}$ de coluna d'água, pode ser visto no Quadro 16. 
Quadro 16 - Intervalo de variação dos valores dos parâmetros de Uni formidade de Emissão, para a pressâo de serviço (Hs) de $8,0 \mathrm{~m}$ de coluna d'água.

\begin{tabular}{cccc}
\hline GOTEJADOR/PLANTA & UE $\left(\begin{array}{c}0 \\
0\end{array}\right)$ & UEa $\left(\begin{array}{c}0 \\
0\end{array}\right)$ & AMM $\left(\begin{array}{c}0 \\
0\end{array}\right)$ \\
\hline 1 & $82,04-78,26$ & $81,89-79,76$ & $22,6-29,2$ \\
2 & $87,25-83,23$ & $87,09-84,83$ & $15,2-21,5$ \\
3 & $89,56-85,43$ & $89,39-87,07$ & $12,3-18,4$ \\
4 & $90,93-86,74$ & $90,77-88,41$ & $.10,6-16,6$ \\
\hline
\end{tabular}

Obs.: Cada intervalo inclui desde a menor razāo de perda de carga (RPC) até a maior.

Com a pressão de serviço adotada de 10,0 m de coluna d'āgua, verificou-se que a Uniformidade de Emissāo de $90 \%$ somente serâ atingida com a utilização de 4 (quatro) gotejadores por planta, para razōes de perda de carga (RPC's) abaixo de 0,50.

0 intervalo de variação dos valores da Uniformidade de Emissão (UE), Uniformidade de Emissão Ab soluta (UEa) e Ārea Mais Molhada (AMM), para a -pressão de serviço (Hs) de $10,0 \mathrm{~m}$ de coluna d'água, pode ser vis to no Quadro 17. 
Quadro 17 - Intervalo de variação dos valores dos parâmetros da Uni formidade de Emissão, para a pressão de serviço (Hs) de $10,0 \mathrm{~m}$ de coluna d'âgua.

\begin{tabular}{cccc}
\hline GOTEJADOR/PLANTA & UE $\left(\begin{array}{c}\frac{0}{0} \\
0\end{array}\right)$ & UEa $\left(\begin{array}{c}o \\
0\end{array}\right)$ & AMM $\left(\begin{array}{c}o \\
0\end{array}\right)$ \\
\hline 1 & $82,13-70,80$ & $82,08-83,01$ & $22,0-19,4$ \\
2 & $87,34-87,87$ & $87,29-88,29$ & $14,7-12,3$ \\
3 & $89,65-87,11$ & $89,60-90,62$ & $11,7-9,4$ \\
4 & $91,03-88,45$ & $90,98-92,01$ & $10,1-7,8$ \\
\hline
\end{tabular}

Obs.: Cada intervalo inclui desde a menor razäo de perda de carga (RPC) até a maior.

Com a pressão de serviço adotada de 12,0 $m$ de coluna d'âgua, verificou-se que a Uniformidade de Emissao de $90 \%$ somente será atingida com a utilização de 4 (quatro) gotejadores por planta, para" qualquer valor da razão de perda de carga (RPC) 。

O intervalo de variação dos valores da Uniformidade de Emissão (UE), Uniformidade de Emissão Absoluta (UEa) e Área Mais Molhada (AMM), para a pressäo de serviço (Hs) de $12,0 \mathrm{~m}$ de coluna d'àgua, pode ser visto no Quadro 18. 
Quadro 18 - Intervalo de variação dos valores dos parâmetros de Uniformidade de Emissão, para a pressão de serviço (Hs) de $12,0 \mathrm{~m}$ de coluna d'água.

\begin{tabular}{cccc}
\hline GOTEJADOR/PLANTA & UE $\left(\begin{array}{c}\circ \\
0\end{array}\right)$ & UEa $\left(\begin{array}{l}\circ \\
0\end{array}\right)$ & AMM $\left(\begin{array}{c}\circ \\
0\end{array}\right)$ \\
\hline 1 & $82,22-81,56$ & $82,28-84,63$ & $21,4-14,9$ \\
2 & $87,44-86,74$ & $87,50-90,00$ & $14,2-8,0$ \\
3 & $89,75-89,03$ & $89,82-92,38$ & $11,2-5,3$ \\
4 & $91,13-90,40$ & $91,20-93,80$ & $9,5-3,7$ \\
\hline
\end{tabular}

Obs.: Cada intervalo inclui desde a menor razão de perda de carga (RPC) atē a maior.

4.4.2 - Coeficiente de Uniformidade na linha la tera 1

Utilizando-se a equação (23), calcularam- se os valores estimados da taxa de fluxo média, para cada respectivo subgrupo, os quais foram determinados atravês de incrementos de $5 \%$ da população total distribuída normalmente.

Os valores calculados do valor médio da variável reduzida $\left(\bar{t}_{\dot{i}}\right)$ foram retirados do trabalho de NAKAYAMA et alii (1978), pois, dentro do mesmo incremento do subgrupo, o valor $\bar{t}_{i}$ será o mesmo, independente das unidades das observações, jā que elas sao distrïbuĩdas normalmente. 
Assim, com os valores calculados da taxa de fluxo média para os 20 subgrupos respectivos, onde fo ram usados $\hat{\mathrm{q}}_{\mathrm{g}}=4,121 / \mathrm{h}$ e $\mathrm{CV}_{\mathrm{fg}}=0,1770$, para o goteja dor IRTEC-1; $\hat{\mathrm{q}}_{\mathrm{g}}=4,97 \mathrm{l} / \mathrm{h}$ e $\mathrm{CV}_{\mathrm{fg}}=0,1403$, para o gotejador IRTEC-2; e $\hat{\mathrm{q}}_{\mathrm{g}}=3,97 \mathrm{I} / \mathrm{h}$ e $\mathrm{CV}_{\mathrm{fg}}=0,0517$, para $\mathrm{O}$ gotejador DANTAS, elaborou-se um gráfico, onde foramplo tados os valores da taxa de fluxo média para cada res-. pectivo subgrupo, obtendo-se uma curva para cada tipo de gotejador.

Para o gotejador DANTAS seguiu-se a mesma consideração feita por SOLOMON (1977), conforme rela tada no item 2.3.2.

O gräfico contendo as triês curvas é apre sentado na Figura 17.

O gráfico mostra claramente que o goteja dor com um menor Coeficiente de Variaçāo de Fabricação (gotejador DANTAS), conduz para uma maior uniformidade de fluxo, como indicado pela variaçāo menor dos subgrupos com as menores e maiores vazões, em relação à taxa de fluxo média do gotejador.

SOLOMON (1977) sugeriu que o Coeficiente de Variação de Fabricação deveria ser menor do que 0,15 para alcançar uma razoável uniformidade de aplicação. 


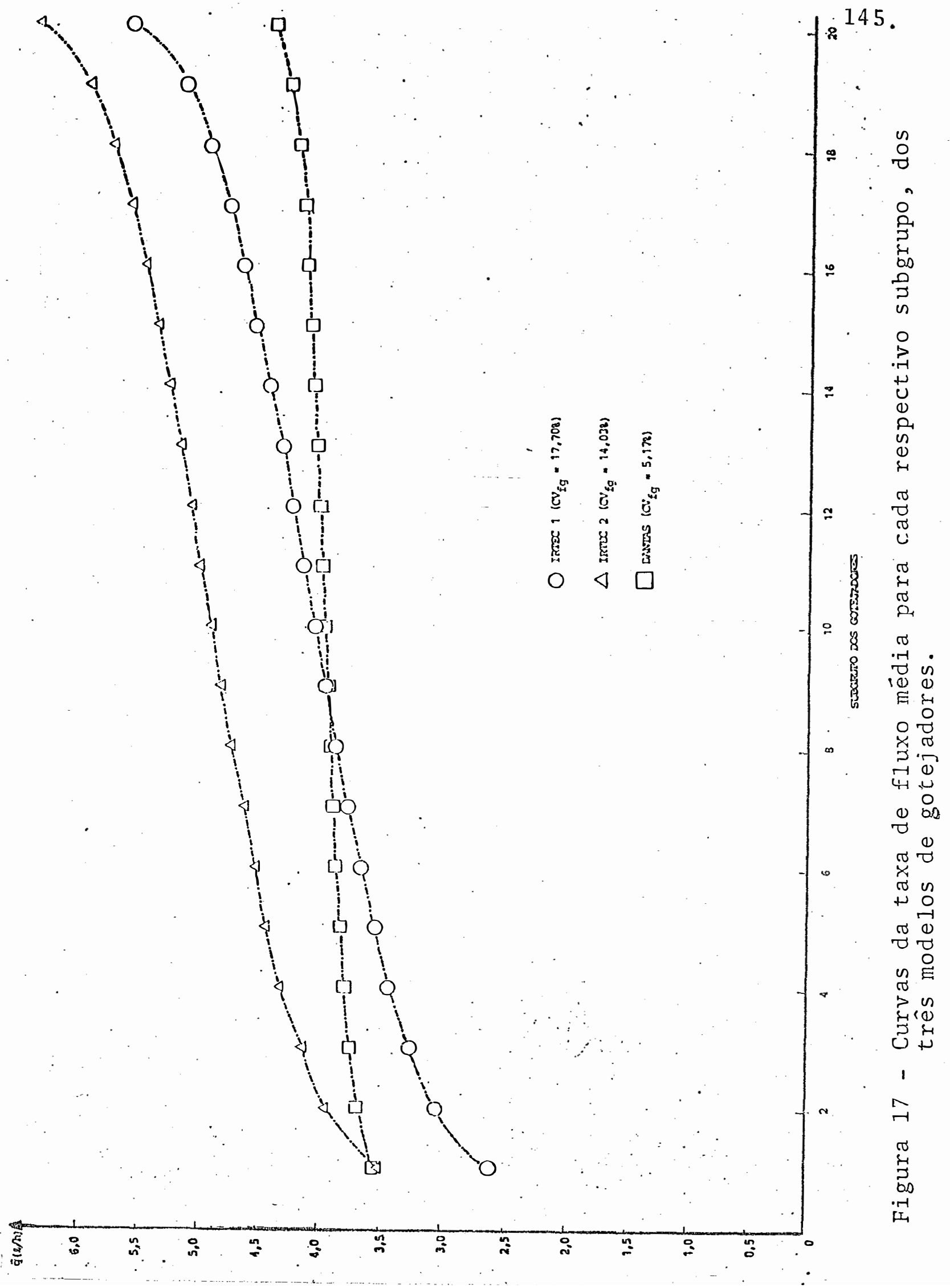


Aumentando-se o nümero de gotejadores por planta, a uniformidade de aplicação pode ser melhorada como mostram as Figuras 18,19 e 20, respectivamente,pa ra os gotejadores IRTEC-1, IRTEC-2 e DANTAS. Neste caso, primeiro foram calculados os valores de $\bar{q}_{i, e}$ usando-se a equação (24), e a seguir os valores de $\bar{q}_{i, e} / e \cdot \bar{q}$, em por centagem, foram plotados versus os respectivos subgrupos do gotejador.

Normalmente, mais do que 1 (um) gotejador por planta é usado na prätica, desde que um ünico gotejador não seja suficiente para fornecer a sua neces sidade diária de água. Tambēm, vários gotejadores por planta dão um melhor modelo de distribuição de āgua ao redor da planta, do que apenas um gotejador.

A seguir, determinou-se o Coeficiente de Uniformidade na linha lateral de irrigação por gotejamento, atravēs da equação (25), onde usou-se o Coeficiente de Variação de Fabricação global de cada respectivo gotejador, variando-se o nümero de gotejadores por planta (e $=1,2,3,4,5$ e 6 gotejadores).

Desta forma, construiu-se um gráfico pl으 tando-se os valores calculados do Coeficiente de Unifor midade na linha lateral ( $\mathrm{CU}_{\mathrm{LL}}$ ) em função do nümero de gotejadores por planta, obtendo-se uma curva para cada 


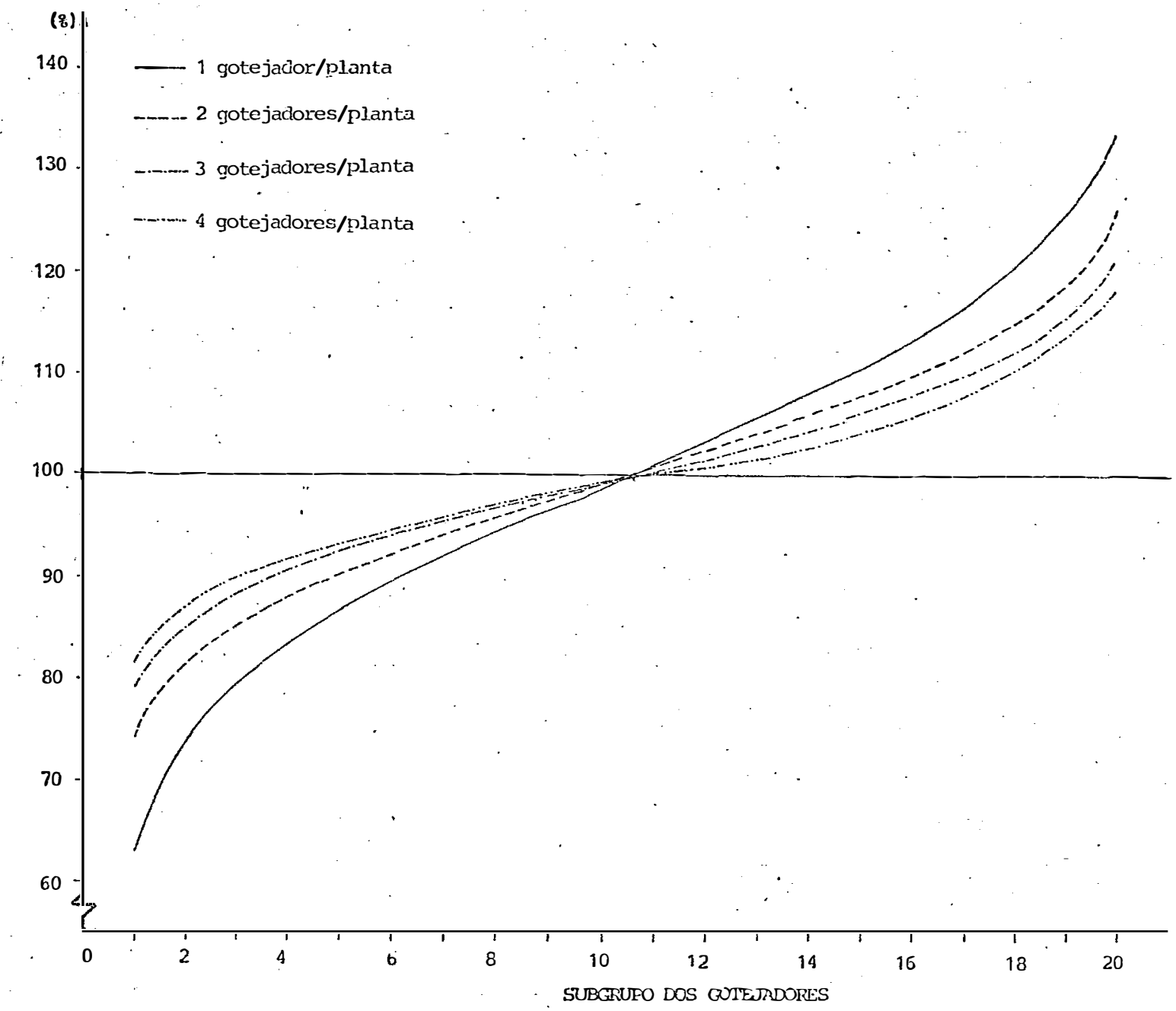

Figura 18 - Efeito do número de gotejadores por planta sobre o desvio da taxa de fluxo média do gotejador IRTEC-1. 


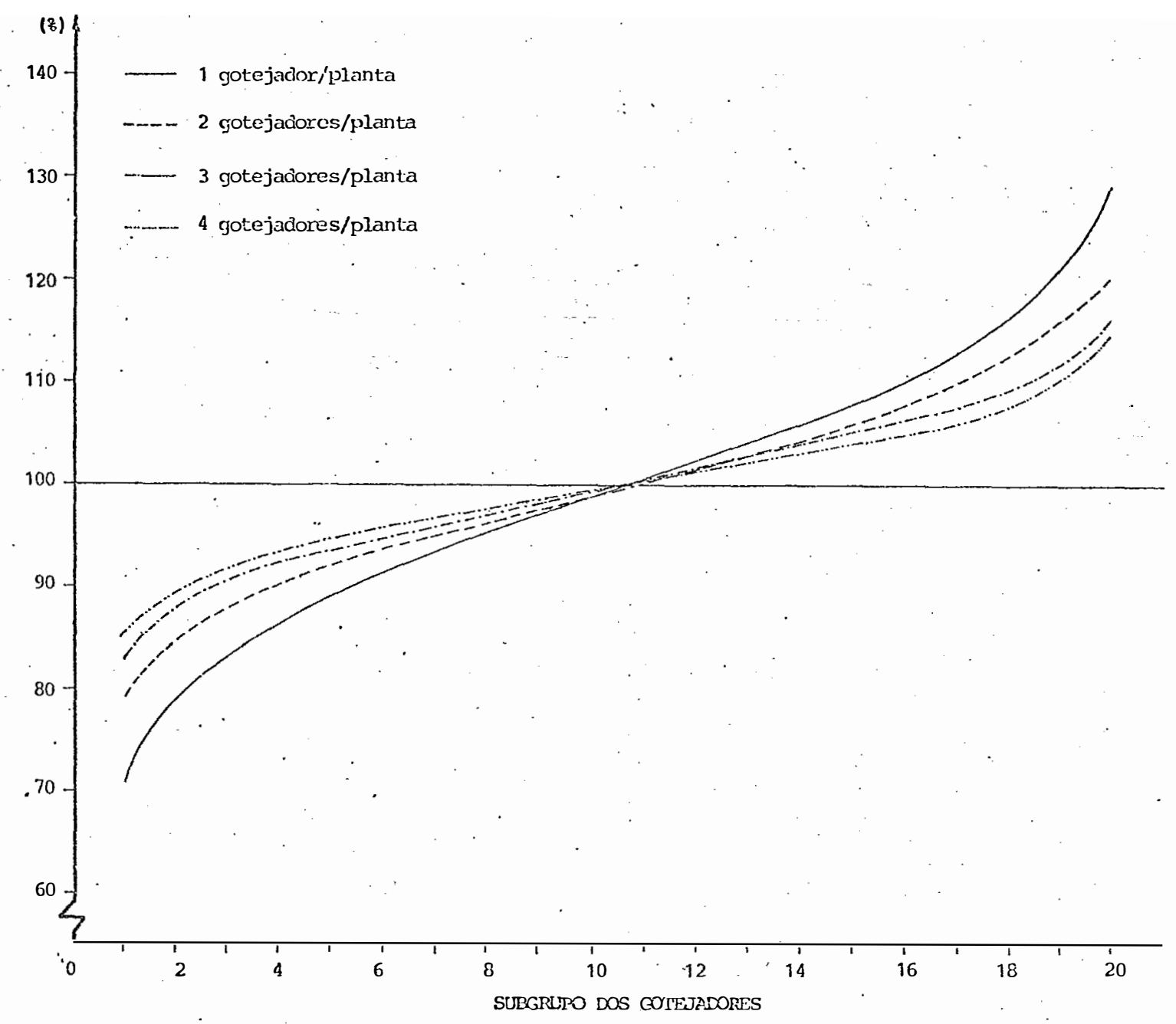

Figura 19 - Efeito do número de gotejadores por planta sobre o desvio da taxa de fluxo média do gotejador IRTEC- 2 . 


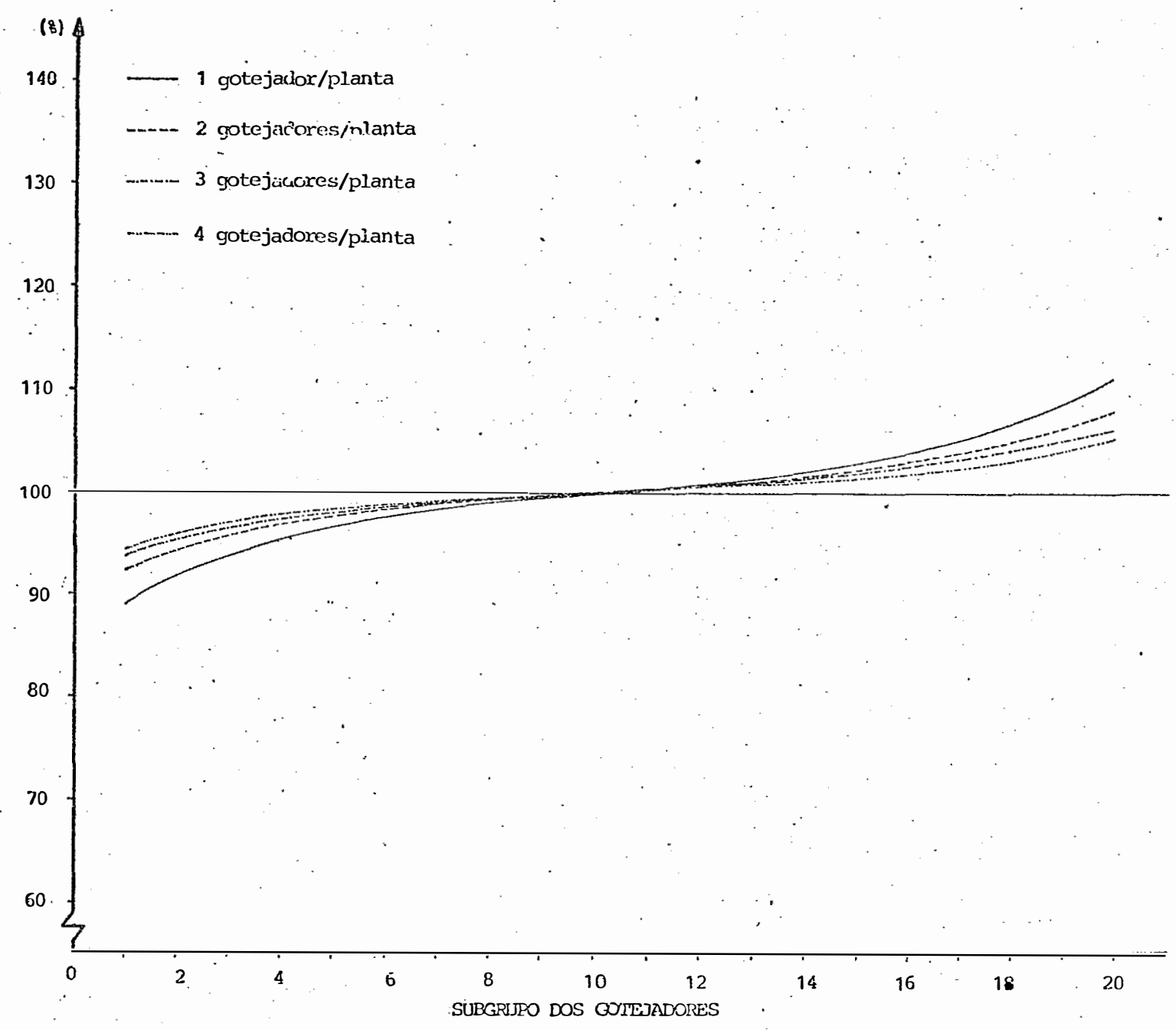

Figura 20 - Efeito do número de gotejadores por planta sobre o desvio da taxa de fluxo média do gotejador DANTAS. 
respectivo gotejador. O gräfico contendo as três curvas é apresentado na Figura 21 .

$$
\text { Analisando-se o gráfico, nota-se que tan }
$$

to para o gotejador IRTEC-1 como para o gotejador IRTEC2, haverá necessidade de colocarem-se 2 gotejadores ou mais por planta, para que o Coeficiente de Uniformidade na linha lateral acima de $90 \%$ possa ser alcançado. En- . quanto que, para o gotejador DANTAS, mesmo com apenas 1 (um) gotejador por planta, o Coeficiente de Uniformidade na linha lateral será cerca de $96^{\circ}$.

Os valores obtidos do Coeficiente de Uni formidade $\left(\mathrm{CU}_{\overline{L L}}\right)$ para o gotejador IRTEC-2 foram todos superiores aos valores obtidos para o gotejador IRTEC-1, para o mesmo número de gotejadores por planta. Enquanto que os valores obtidos para o gotejador DANTAS, foram sempre bem superiores em relação aos outros dois goteja dores.

Assim, com os valores do Coeficiente de Variação de Fabricação determinado para o gotejador, o projetista de um sistema de irrigação pode razoavelmente estimar a uniformidade de aplicação ótima esperada. Alēm do mais, a comparação entre o Coeficiente de Uniformidade do projeto, o Coeficiente de Variação de Fabricação do gotejador e o número de gotejadores por plan 


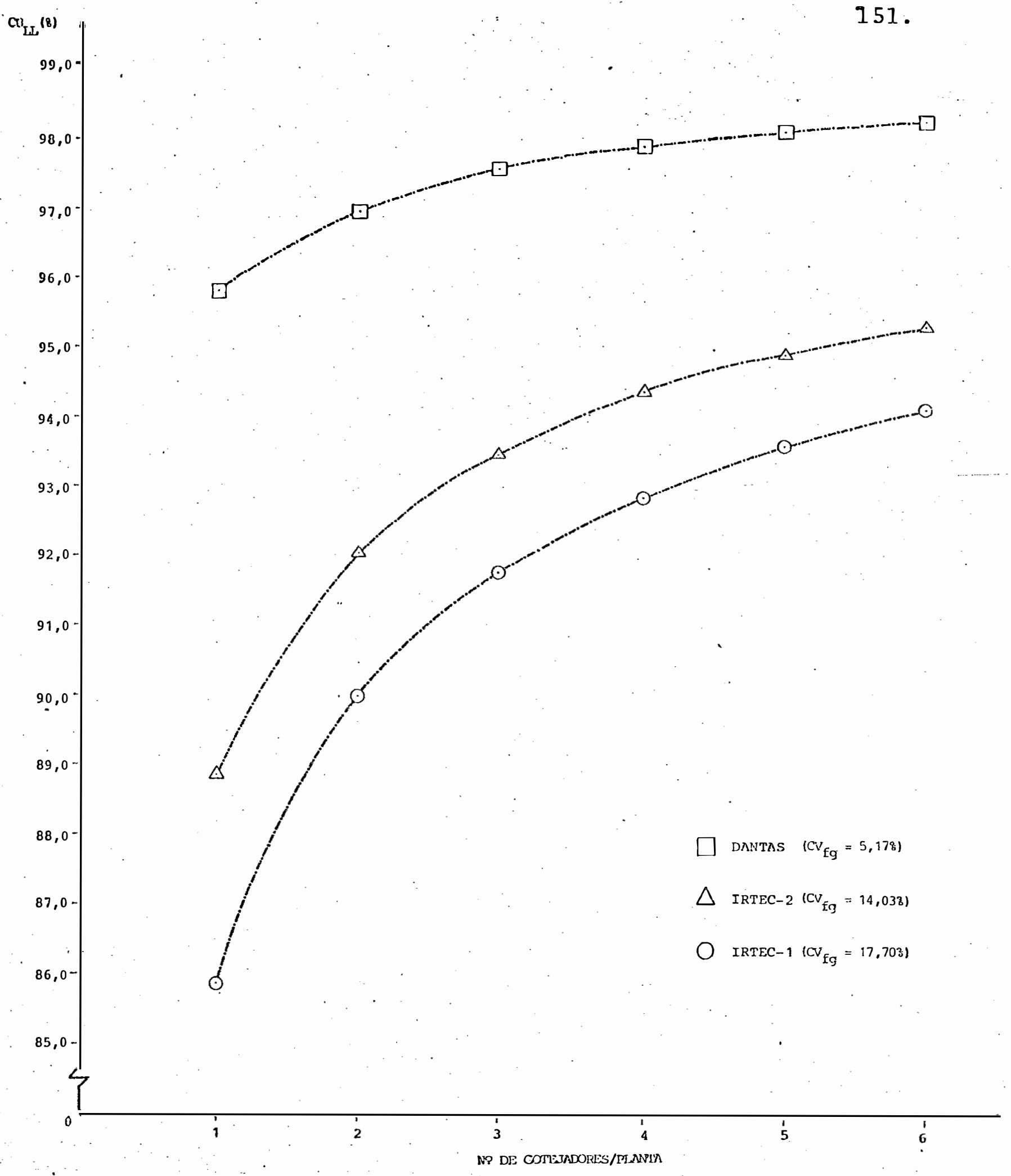

Figura 21 - Curvas do Coeficiente de Uniformidade na 1inha lateral ( $\left.\mathrm{CU}_{\mathrm{L}}\right)$, em função do :-nümero de gotejadores por $\mathrm{p} l a n t a$, para os três modelos experimentados. 
ta enfatiza a necessidade do fabricante em produzir gotejadores com um coeficiente de variação tão baixo quan to possive1, e para o qual o coeficiente não aumente drasticamente após a instalação e operação.

Com a finalidade de encontrar-se o Tempo Corrigido de Irrigação, que è determinado através do prọ duto de um fator de tempo e o tempo de aplicação, calcu . lado do volume de ägua necessärio e a taxa de fluxo mēdia do gotejador por planta, é que elaborou-se a tabela apresentada no Quadro 19.

Nesta tabela, o fator de tempo foi deter minado através da equaçäo (26), onde usou-se o Coeficiente de Variação de Fabricação global ( $\left.\mathrm{CV}_{f g}\right)$ do respectivo gotejador, variando-se o número de gotejadores por planta (e $=1,2,3,4,5$ e 6 gotejadores), para três níveis de fração de plantas que seriam esperadas estarem adequadamente irrigadas $(\mathrm{a}=95 \%, 90 \%$ e $85 \%$ ).

Por exemplo, se o tempo de irrigação cal culado é para ser de 10 horas, para uma suficiência de irrigação de $90 \%$ com 1 (um) gotejador por planta, o Tem po Corrigido de Irrigaçāo seria 10,70 hs para o gotejador DANTAS, 12,17 hs para o gotejador IRTEC-2 e 12,90 hs para o gotejador IRTEC-1. 
Quadro 19. - Valores do fator que irā corrigir o tempo de irrigação, para três níveis de fração de plan tas adequadamente irrigadas, em função do nü mero: de gotejadores por planta.

\begin{tabular}{|c|c|c|c|c|c|c|c|}
\hline \multirow{2}{*}{$\begin{array}{c}\mathrm{a}^{*} \\
\left(\begin{array}{c}0 \\
0\end{array}\right)\end{array}$} & \multirow{2}{*}{$\begin{array}{c}\mathrm{CV}_{\text {fg }} \\
\left(\begin{array}{l}0 \\
0\end{array}\right)\end{array}$} & \multicolumn{6}{|c|}{ GOTEJADORES/PLANTA } \\
\hline & & $e=1$ & $e=2$ & $e=3$ & $e=4$ & $e=5$ & $e=6$ \\
\hline \multirow{3}{*}{$95 \%$} & 5,17 & 1,093 & 1,064 & 1,051 & 1,044 & 1,039 & 1,036 \\
\hline & 14,03 & 1,299 & 1,194 & 1,153 & 1,130 & 1,115 & 1,104 \\
\hline & 17,70 & 1,409 & 1,258 & 1,201 & 1,170 & 1,149 & 1,134 \\
\hline & . & & & & & & \\
\hline \multirow{3}{*}{$90^{\circ}$} & 5,17 & 1,070 & 1,049 & 1,039 & 1,034 & 1,030 & 1,028 \\
\hline & 14,03 & 1,217 & 1,144 & 1,115 & 1,098 & 1,087 & $1,07 \varepsilon$ \\
\hline & 17,70 & 1,290 & 1,189 & 1,149 & 1,127 & 1,112 & 1,101 \\
\hline \multirow{3}{*}{$85^{\circ}$} & 5,17 & 1,045 & 1,032 & 1,026 & 1,022 & 1,020 & 1,018 \\
\hline & 14,03 & 1,134 & 1,091 & 1,073 & 1,063 & 1,056 & 1,051 \\
\hline & 17,70 & 1,175 & 1,117 & 1,094 & 1,080 & 1,071 & 1,065 \\
\hline
\end{tabular}

*a = fração de plantas adequadamente irrigadas. 


\title{
5. CONCLUSÕES
}

\author{
Através da anālise dos resultados obti- \\ dos nos testes realizados com os três modelos de goteja \\ dores experimentados, pode-se concluir que: \\ 1 - Os resultados da correlação linear entre a va- \\ zão do gotejador com a temperatura ambiente d'água, bem \\ como com a vazão da linha lateral, isto dentro do inter \\ valo de variação ocorrido durante a realização dos tes- \\ tes de Uniformidade de Vazão, permitem considerar que a \\ maior parte da variação observada na vazão entre os go- \\ tejadores foi devida às diferenças entre os mesmos de- \\ correntes de sua fabricação. \\ 2 - O Coeficiente de Variação de Fabricação $\left(\mathrm{CV}_{f}\right)$ \\ pode diferir entre as amostras testadas de cada goteja-
}


dor, embora estes valores tenham se definido claramente dentro de intervalos específicos para cada modelo de go tejador experimentado.

3 - Com a reunião dos valores de vazão das três amostras de cada modelo de gotejador, determinou-se o Coe. ficiente de Variação de Fabricação global $\left(\mathrm{CV}_{f g}\right)$, revelando um valor bem menor para o gotejador DANTAS $\left(5,17^{\circ}\right)$, em comparação com o microgotejador IRTEC-2 $(14,03 \%)$ e com o gotejador IRTEC-1 $(17,70 \%)$.

4 - Na verificação de normalidade à distribuição das taxas de vazão dos gotejadores amostrados em cada teste de Uniformidade de Vazão, pode ocorrer, para um determinado tipo de gotejador, uma não aderência de seus dados à distribuição normal proposta.

5 - As equações características de vazão-pressão pa ra os gotejadores testados foram as seguintes:

IRTEC-1 :

$$
\widehat{\mathrm{q}}=3,680 \quad \cdot \mathrm{H}^{-0,028}
$$

IRTEC- 2:

$$
\begin{aligned}
\hat{\mathrm{q}}=2,273 & +0,456 \mathrm{H}-3,14810^{-2} \mathrm{H}^{2}+ \\
& +6,595 \cdot 10^{-4} \mathrm{H}^{3}
\end{aligned}
$$

DANTAS :

$$
\hat{\mathrm{q}}=1,097 \cdot \mathrm{H}^{0,526}
$$


6 - Os valores do coeficiente de variação calculados para cada pressão aplicada sobre os gotejadores amostrados, revelaram-se muito altos, principalmente para o gotejador IRTEC-1 em relação ao gotejador IRTEC-2. Jâ para o gotejador DANTAS, observaram-se valores mais baixos, evidenciando uma pequena dispersão dos valores de vazão dentro de uma mesma pressão aplicada,o que vem confirmar os baixos valores do Coeficiente de Variação de Fabricação obtidos durante os testes de Uniformidade de Vazão.

7 - As tabelas de Uniformidade de Emissão mostram que para o gotejador IR'TEC-1, nos três niveis de pressão de serviço, até com quatro gotejadores por planta, não será atingida uma Uniformidade de Emissão de $90 \%$, com qualquer valor da razão de perda de carga. Já para o microgotejador IRTEC-2, esta uniformidade de $90 \%$ somente será atingida com a utilização de quatro gotejado res por planta, sendo que para pressões de serviço adotadas de $8,0,10,0$ e $12,0 \mathrm{~m}$ de coluna d'água, pode-se permitir uma razão de perda de carga abaixo de 0,30, 0,50 e com qualquer valor, respectivamente. Enquanto que para o gotejador DANTAS, a Uniformidade de Emissão de 90\% poderá ser atingida com a adoção de valores mais altos para a razão de perda de carga, com o aumento do nümero 
de gotejadores por planta. Assim, pode-se permitir uma razão de perda de carga até $0,30,0,40$ e 0,50, respecti vamente para 1,2 e 3 ou 4 gotejadores por planta.

8 - Um menor Coeficiente de Variação de Fabricação do gotejador conduziu para uma maior uniformidade de flu xo, conforme indicado pela menor variação dos grupos de gotejadores com as menores e maiores taxas de fluxo, em relação à taxa de fluxo média do gotejador. Tambēm, ficou evidenciado que aumentando-se o número de gotejadores por planta, a uniformidade de aplicaçâo pode ser me 1horada.

9 - Com rëlação ao Coeficiente de Uniformidade na linha lateral de irrigação, tanto para o gotejador IRTEC-1 como para o gotejador IRTEC-2, haverá necessidade de colocar-se 2 (dois) gotejadores ou mais por planta, para que um coeficiente acima de $90 \%$ seja alcançado. En quanto que, para o gotejador DANTAS, mesmo com apenas 1 (um) gotejador por planta, este coeficiente será cerca de $96 \%$.

10 - Se o Coeficiente de Variação de Fabricação do gotejador for elevado, o Tempo Corrigido de Irrigação se rá relativamente maior, para que uma determinada porcen tagem de plantas fosse esperada estar adequadamente irrigada. 


\section{LITERATURA CITADA}

BERNARDO, S., 1980. Irrigação por gotejamento. Viçosa, UFV, Imprensa Universitária. 72 p. [Mimeografado].

BERNARDO,S..1982. Manual de Irrigação. Viçosa, UFV, Imprensa Universitária. 463 p.

BUCKS, D.A. e L.E. MEYERS, 1973. Trickle irrigationaplication uniformity from simple emitters. Trans. Am. Soc. Agric. Engrs., Michigan, 16 (6): 1108-1111.

CAMPOS, H., 1979. Estatística Experimental Não-Paramë-. trica. 3ạ ed. Piracicaba, Deptọ de Matemática e Estatistica da ESALQ/USP. 343 p.

FARIA, M.A., 1981. Características hidráulicas do microgotejador IRTEC e da linha lateral de irrigação. Viçosa, UFV, Imprensa Universitária, 78 p. [Dissertação de Mestrado]. 
GOLDBERG, D. e M. SHMUELI, 1970. Drip irrigation - A method used under arid and desert conditions of high water and soil salinity. Trans. Am. Soc. Agric. Engrs. Michigan, 15 (1): 38-41.

GOLDBERG, D.; B. GORNAT e D. RIMON, 1976. Drip irrigation: principles, design and agricultural practices. Drip Irrigation Scientific Publications, Israel, p. $182-205$.

GUSTAFSON, C.D., 1971. Drip irrigation: a promising can didate but few votes are in. Western Fruit Growers, $\underline{5}(4): 8,13-16$.

HANSON, G.R., 1973. Hydraulics of trickle irrigation emit ter lines. Logan, Utah State University, 94 p. [Dis sertação de Mestrado].

HART, W.E., 1961. Overhead irrigation pattern parameters. Agric. Engng., 42: 354-355.

HOWELL, T.A. e E.A. HILER, 1974a. Trickle irrigation 1ateral design. Trans. Am. Soc.Agric. Engrs., Michigan, $\underline{17}(5)$ : $902-908$.

HOWELL, T.A. e E.A. HILER, 1974b. Designing trickle irrigation laterals for uniformity. J. Irrig. Drain. Div. Am. Soc. Civ. Engrs., New York, 100 (IR4): 443-454 .

KELLER, J. e D. KARMELI, 1974a. Trickle Irrigation Design. Glendora, Rain Bird Sprinkler Mfg. Corp. 182 p. 
KELLER, J。 e D. KARMELI, 1974b. Trickle irrigation design parameters. Trans. Am.Soc. Agric. Engrs., Michigan, 17(4): 678-684。

KENWORTHY, A.L。, 1972. Trickle irrigation... the concept and guidelines for use. Research Report 165. Michigan, Michigan State University.

KENWORTHY, A.L. e C. KESNER, 1974. Trickle irrigation in Michigan orchards: controlling rate of flow regulating valves and microtubes. In: Proceedings of the Second International Drip Irrigation Congress, San Diego, p. 275-280.

MERRIAN, J.L。; J. KELLER e J. ALFARO, 1975. Irrigation system evaluation and improvement. Logan, Agricultum re and Irrigation Engineering Department, Utah State University.

MEYERS, L.E. e D.A. BUCKS, 1972. Uniform irrigation with low-pressure trickle systems. J. Irrig. Drain. Div. Am. Soc. Civ. Engrs., New York, 98(IR3): 341-346.

NAKAYAMA, F.S.; D.A. BUCKS e A.J. CLEMMENS, 1978. Assessing trickle emitter application uniformity. In: 1978 Summer Meeting Am. Soc. Agric. Engrs,, Logan, Utah State University. ASAE, paper no 78-2017.

OLITTA, A.F.L., 1977。 Os Mêtodos de Irrigação. São Pau 10, Livraria Nobel S.A. 267 p. 
OLIVEIRA, C.A.S.-, 1978. Hidräulica de gotejadores e de $\underline{\text { ii }}$ nhas laterais para irrigaçäo por gotejamento. Viçosa, UFV, Imprensa Universitäria, 72 p. [Dissertação de Mestrado].

SOLOMON, K., 1976. Emission uniformity - an introduction. In: Proceedings, 1976 Annual Meeting of the International Drip Irrigation Association, Fresno, p. 4. -6 .

SOLOMON, K., 1977. Manufacturing variation of emitters in trickle irrigation systems. In: 1977 Annual Meeting Am. Soc. Agric. Engrs, Raleigh, North Carolina State University。 ASAE, Paper no 77-2009.

SOLOMON, K。 e J. KELLER, 1978. Trickle irrigation uniformity and efficiency. J. Irrig. Drain. Div. An. Soc. Civ. Engrs., New York, 104 (IR3): 293-306.

WU, I,P.e H.M. GITLIN, 1973. Hydraulics and uniformity for drip irrigation. J. Irrig. Drain. Div. Ann. Soc. Civ. Engrs., New York, 99(IR2): 157-168. 
1.62 .

A

DADOS OBTIDOS NOS TESTES DE UNIFORMIDADE DE VAZÃO. 


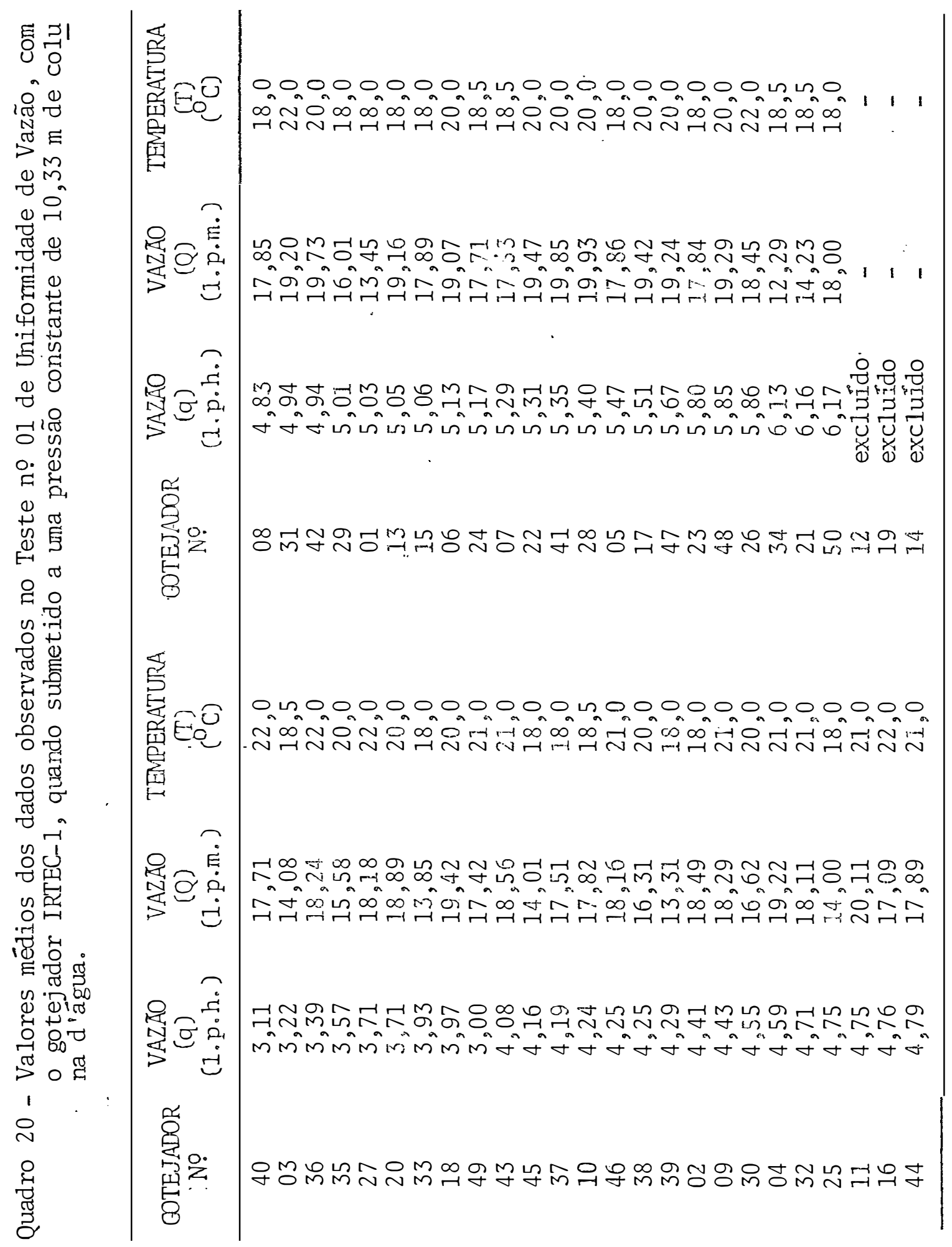




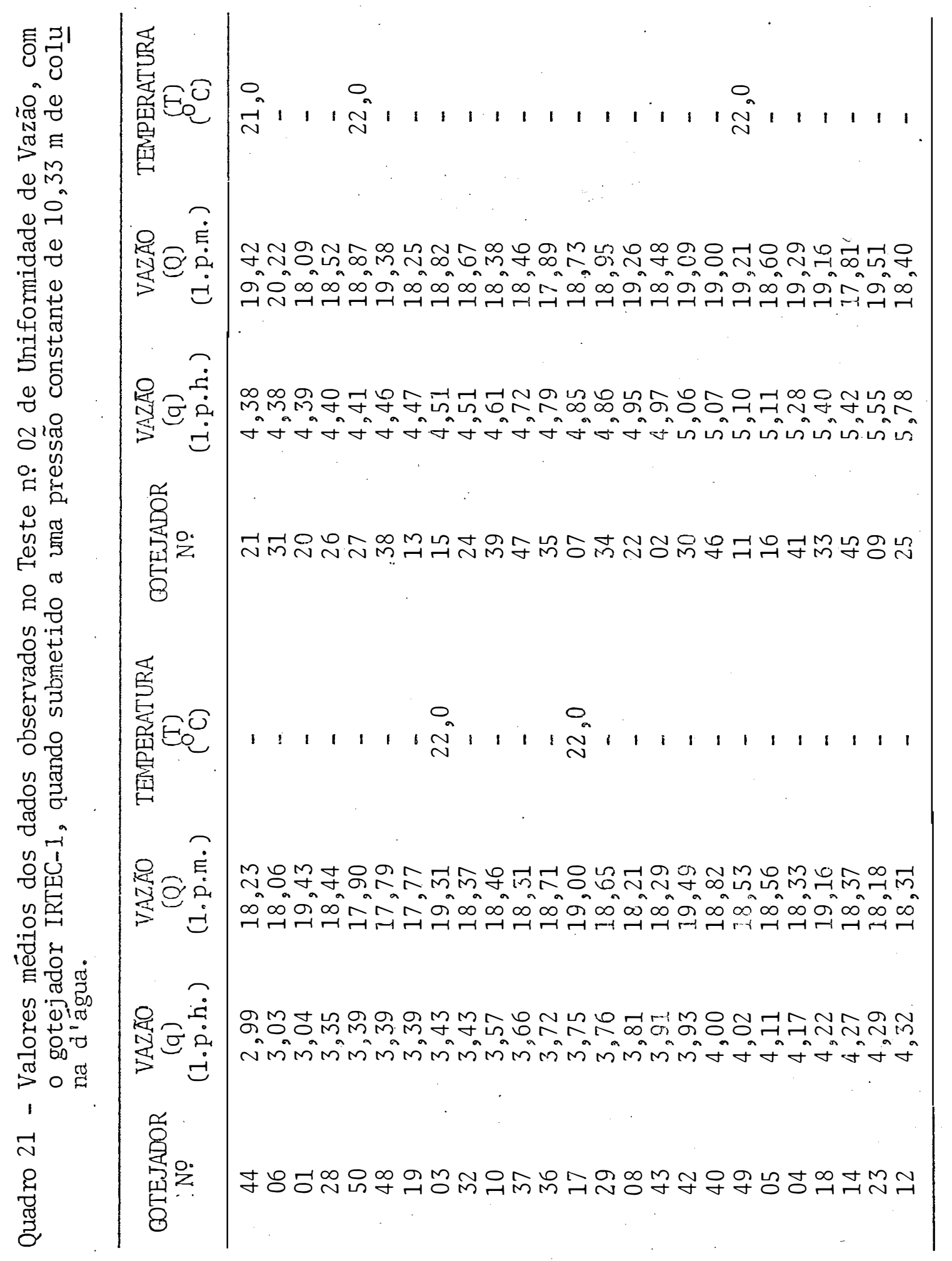




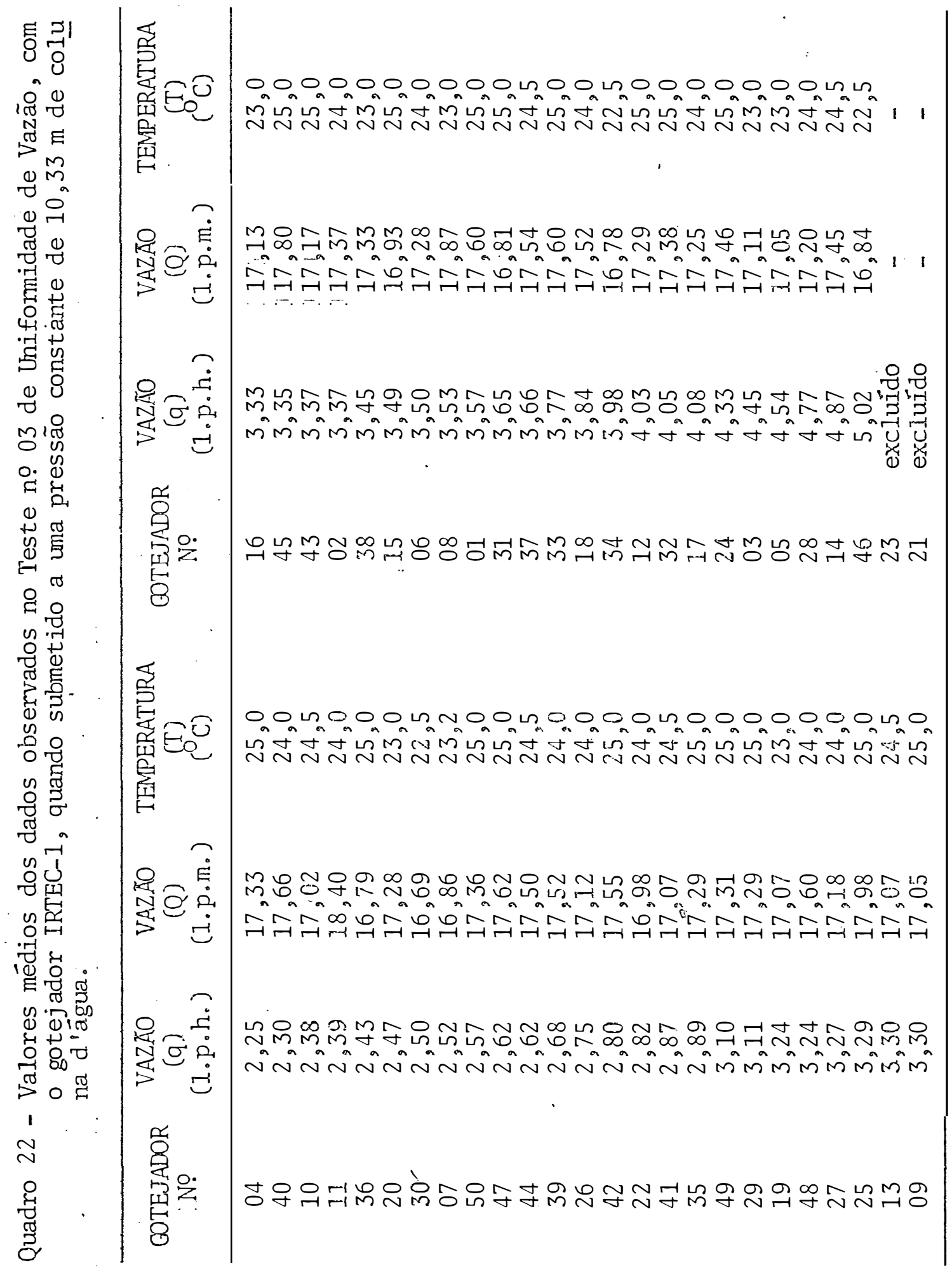




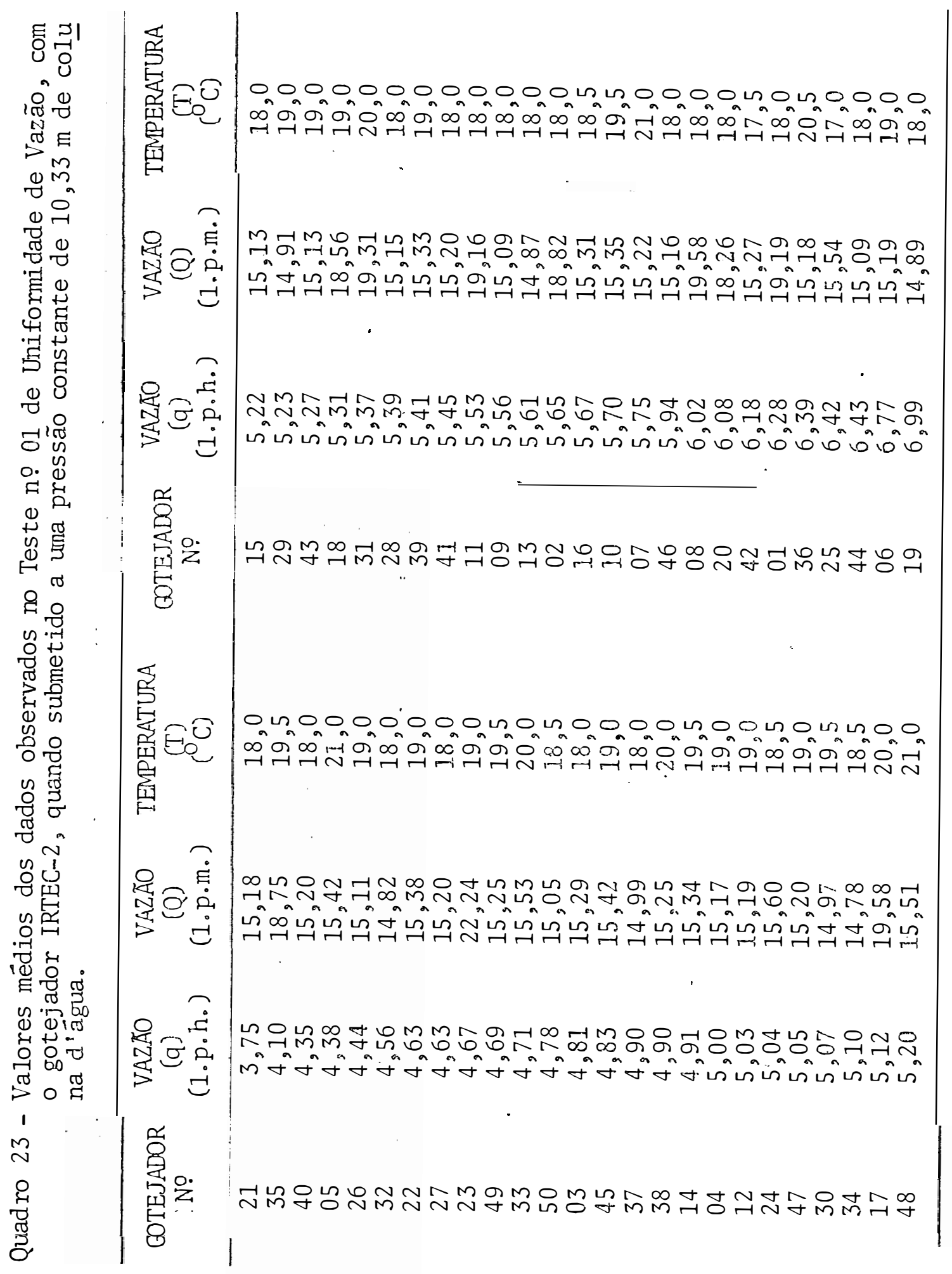




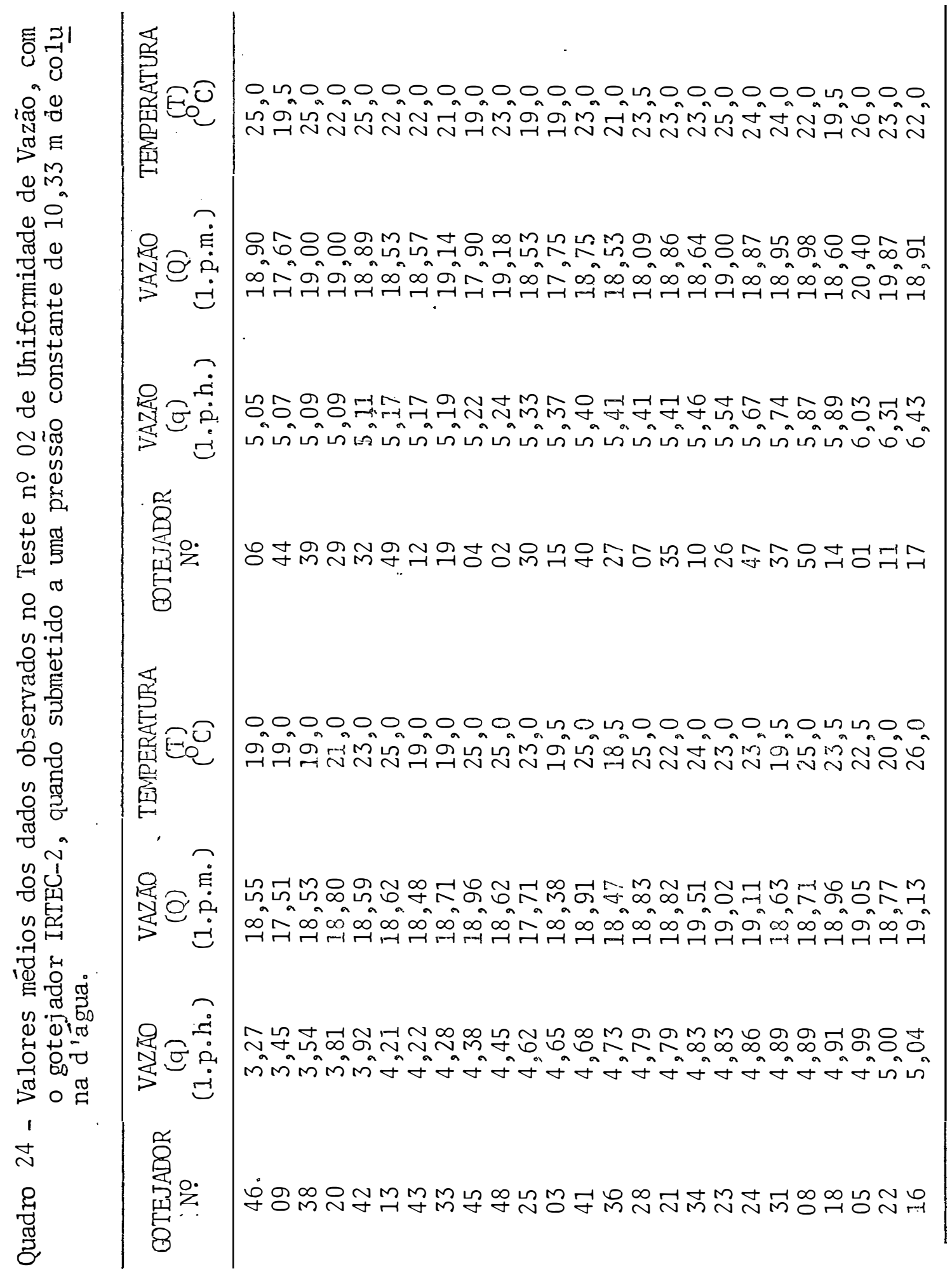




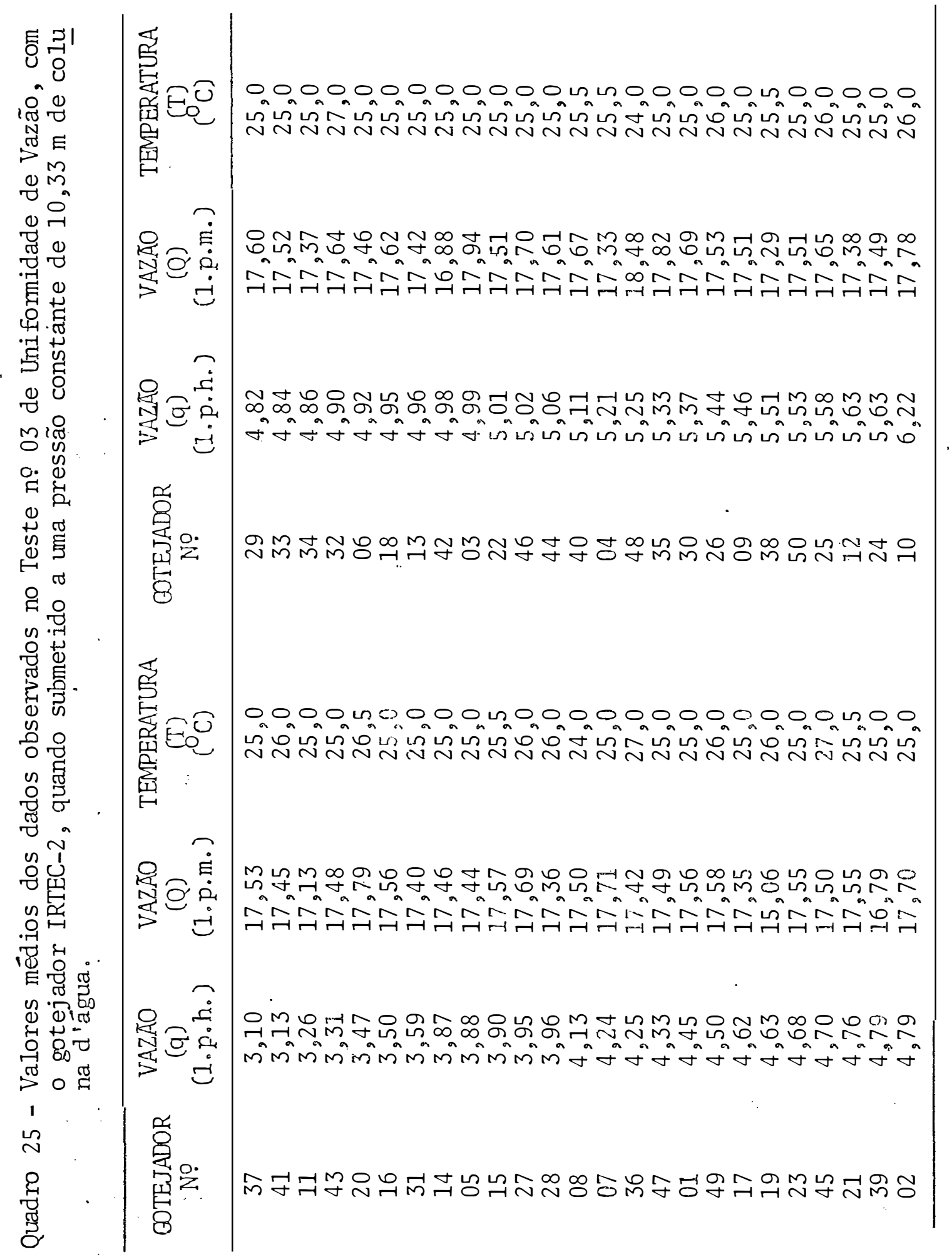




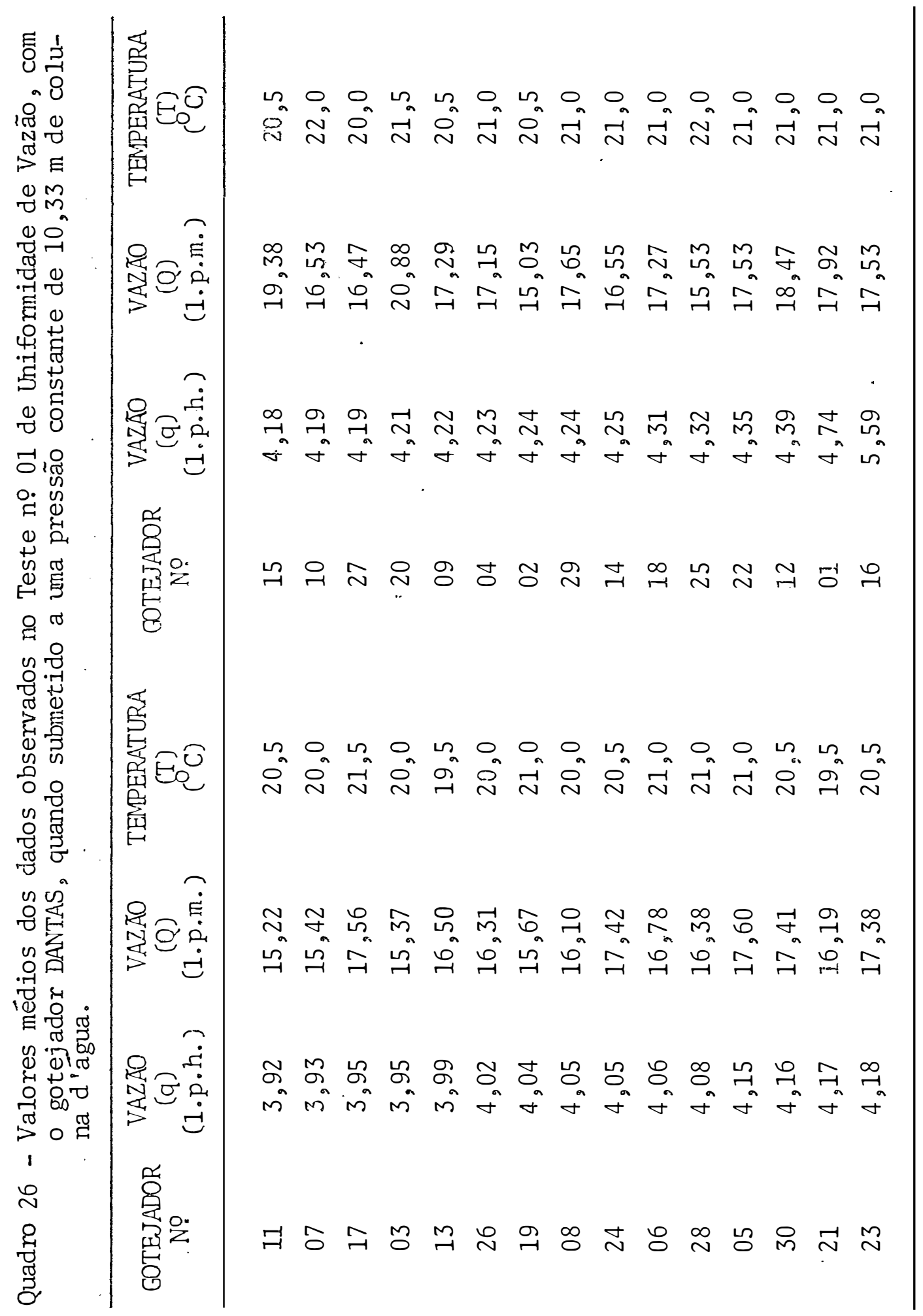




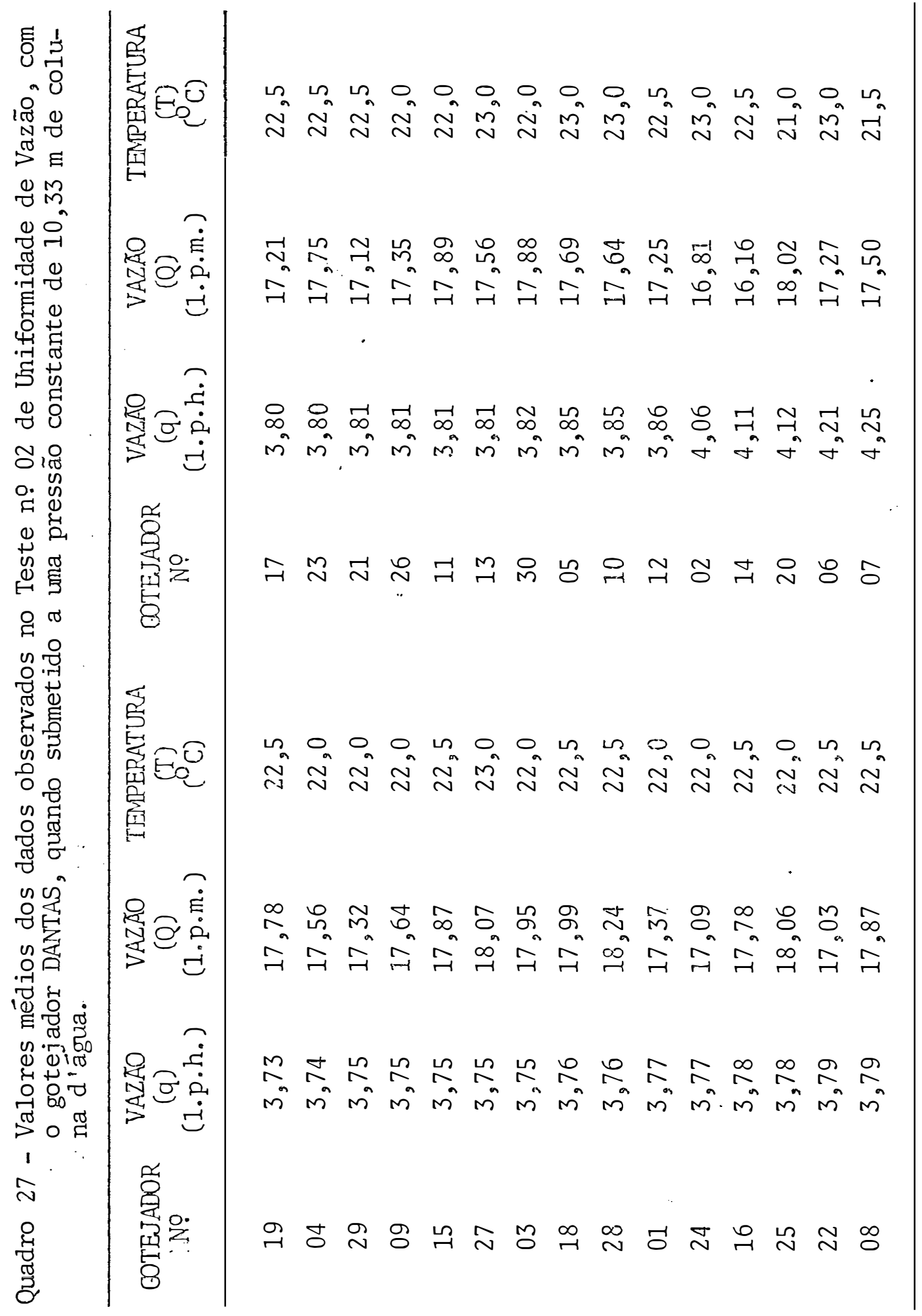




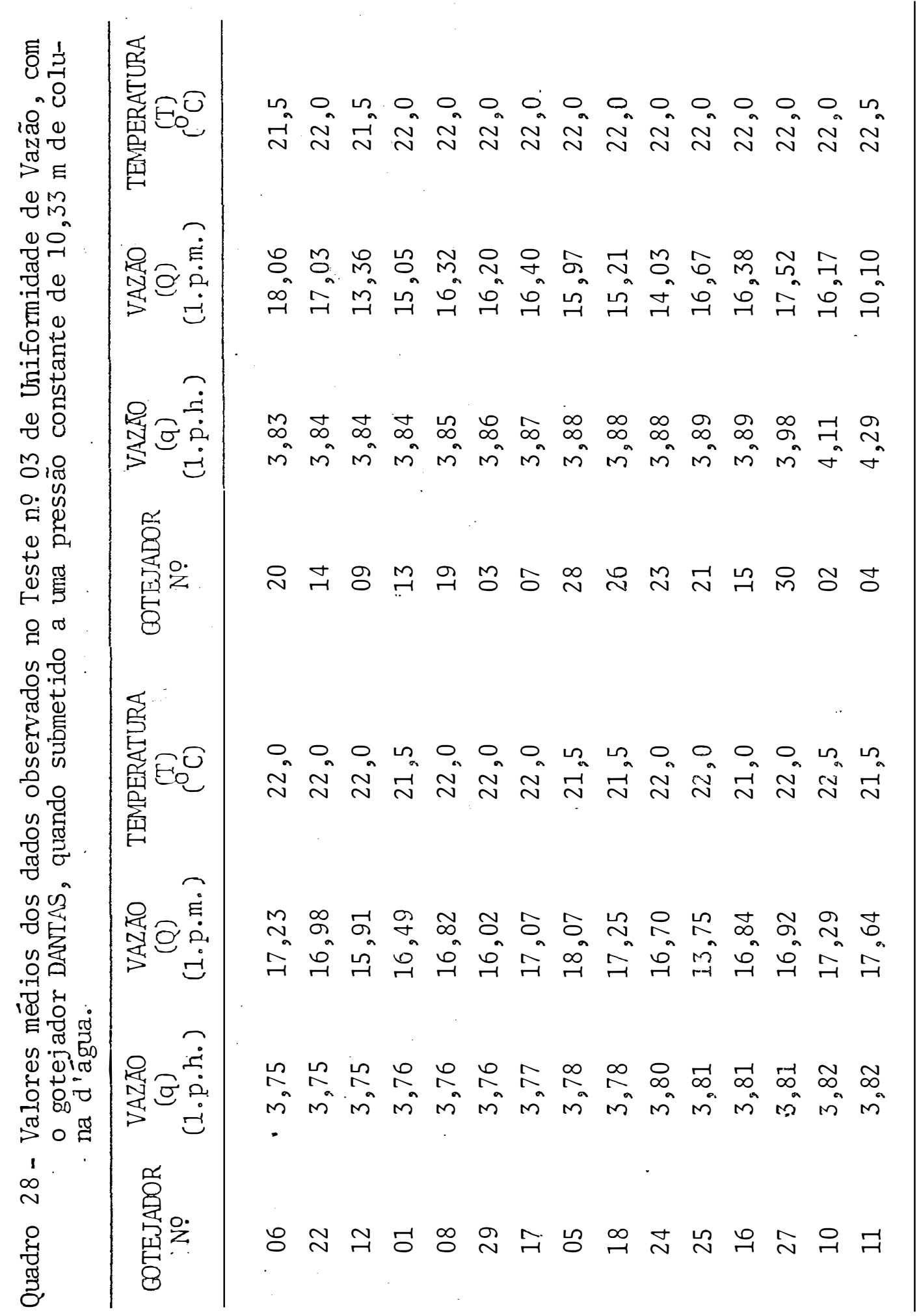


172.

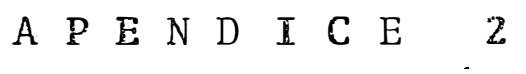

RESULTADOS GERAIS DOS TESTES DE UNIFORMIDADE DE VAZÃO。 
Quadro 29 - Resultados gerais obtidos no Teste n? 01 de Uniformida de de Vazão, referentes ao gotejador IRTEC-1, quando submetido a uma pressão constante de 10,33 in de coluna d'água.

\begin{tabular}{|c|c|c|c|}
\hline PARÂMETROS ESTATISTICOS & $\bar{q}$ & $\bar{Q}$ & $\mathrm{~T}$ \\
\hline Mëdia & 4,74 & 17,50 & 19,64 \\
\hline Variância & 0,61 & 4,13 & 2,07 \\
\hline Desvio padrão & 0,78 & 2,03 & 1,44 \\
\hline Variância da média" & 0,01 & 0,09 & 0,04 \\
\hline Erro padrão da média & 0,11 & 0,30 & 0,21 \\
\hline $\begin{array}{l}\text { Intervalo de confiança* } \\
\quad(1-\alpha=0,95)\end{array}$ & $4,52-4,96$ & $16,90-18,10$ & $19,22-20,06$ \\
\hline Coeficiente de Variação & $16,51 \%$ & $11,61 \%$ & $7,33 \%$ \\
\hline
\end{tabular}

sendo: $\bar{q}=$ vazão média do gotejador, em 1/h;

$\overline{\mathrm{Q}}=$ vazão mëdia da linha latera 1 , em $1 / \mathrm{m}$;

$\overline{\mathrm{T}}$ = temperatura média da ägua, em ${ }^{\mathrm{O}} \mathrm{C}$. 
Quadro 30 - Resultados gerais obtidos no Teste no 02 de Uniformida de de Vazão, referentes ao gotejador IRTEC-1, quandosubmetido a una pressão constante de $10,33 \mathrm{~m}$ de coluna d'água .

\begin{tabular}{|c|c|c|c|}
\hline PARAMETROS ESTATISTICOS & $\bar{q}$ & $\bar{Q}$ & $T$ \\
\hline Média & 4,29 & 18,66 & 21,80 \\
\hline Variância & 0,50 & 0,29 & - \\
\hline Desvio padrão & 0,70 & 0,54 & - \\
\hline Variância da média & 0,01 & 0,006 & - \\
\hline Erro padrão da média & 0,10 & 0,08 & - \\
\hline $\begin{array}{l}\text { Intervalo de confiança* } \\
\quad(1-\alpha=0,95)\end{array}$ & $4,09-4,49$ & $18,51-18,81$ & - \\
\hline Coeficiente de Variação & $16,41 \%$ & $2,87 \%$ & - \\
\hline
\end{tabular}

sendo: $\bar{q}=$ vazão média do gotejador, em $1 / \mathrm{h}$;

$\bar{Q}=$ vazão média da linha lateral, em $1 / \mathrm{m}$;

$\overline{\mathrm{T}}$ = temperatura média da água, em ${ }^{\mathrm{O}} \mathrm{C}$. 
Quadro 31 - Resultados gerais obtidos no Teste no 03 de Unifornida de de Vazão, referentes ao gotejador IRTEC-1, quando submetido a uma pressão constante de $10,33 \mathrm{~m}$ de coluna d'água .

PARAMETROS EST'ATISTICOS

$\bar{q}$

$\bar{Q}$

T

Média

3,33

17,30

24,20

Variância

0,51

0,11

0,70

Desvio padrão

0,72

0,34

0,84

Variância da média

0,01

0,002

0,01

Erro padrão da média

0,10

0,05

0,12

Intervalo de confiança* $(1-\alpha=0,95)$

$$
3,13-3,53
$$

$17,20-17,40$

$23,96-24,44$

Coeficiente de Variação

$21,54^{\circ}$

$1,95 \%$

$3,46 \%$

sendo: $\bar{q}=$ vazão mëdia do gotejador, em $1 / \mathrm{h}$;

$\bar{Q}=$ vazão média da linha lateral, em $1 / \mathrm{m}$;

$\overline{\mathrm{T}}=$ temperatura média da água, em ${ }^{\mathrm{O}} \mathrm{C}$. 
Quadro 32 - Resultados gerais obtidos no Teste no 01 de Uniformida de de Vazão, referentes ao gotejador IRTEC-2, quando submetido a uma pressão constante de $10,33 \mathrm{~m}$ de coluna de ägua.

\begin{tabular}{|c|c|c|c|}
\hline PARÂMETROS ESTATISTICOS & $\bar{q}$ & $\bar{Q}$ & $T$ \\
\hline Média & 5,29 & 16,03 & 18,79 \\
\hline Variância & 0,48 & 3,06 & 0,89 \\
\hline Desvio padrão & 0,69 & 1,75 & 0,94 \\
\hline Variância da média " & 0,01 & 0,06 & 0,02 \\
\hline Erro padrão da média & 0,10 & 0,25 & 0,13 \\
\hline $\begin{array}{l}\text { Intervalo de confiança* } \\
\quad(1-\alpha=0,95)\end{array}$ & $5,09-5,49$ & $15,53-16,53$ & $18,53-19,05$ \\
\hline Coeficiente de Variação & $13,07^{\circ}$ & $10,92^{\circ}$ & $5,02 \%$ \\
\hline
\end{tabular}

sendo: $\bar{q}=$ vazão média do gotejador, em $1 / \mathrm{h}$;

$\bar{Q}=$ vazão média da linha lateral, em $1 / \mathrm{m}$;

$\overline{\mathrm{T}}=$ temperatura média da água, em ${ }^{\mathrm{O}} \mathrm{C}$ 。 
Quadro 33 - Resultados gerais obtidos no Teste no 02 de Uniformida de de Vazão, referentes ao gotejador IRTEC-2, quando submetido a uma pressão constante de $10,33 \mathrm{~m}$ de coluna d'água.

\begin{tabular}{|c|c|c|c|}
\hline PARAMETROS ESTATISTICOS & $\bar{q}$ & $\bar{Q}$ & $\mathrm{~T}$ \\
\hline Média & 4,97 & 18,74 & 22,28 \\
\hline Variância & 0,45 & 0,25 & 5,31 \\
\hline Desvio padrão & 0,67 & 0,50 & 2,30 \\
\hline Variância da média " & 0,009 & 0,005 & 0,11 \\
\hline Erro padrão da média & 0,095 & 0,071 & 0,33 \\
\hline $\begin{array}{l}\text { Intervalo de confiança* } \\
\qquad(1-\alpha=0,95)\end{array}$ & $4,78-5,16$ & $18,60-18,88$ & $21,62-22,94$ \\
\hline Coeficiente de Variação & $13,53^{\circ}$ & $2,69 \%$ & $10,34 \%$ \\
\hline
\end{tabular}

sendo: $\bar{q}=$ vazão média do gotejador, em $1 / \mathrm{h}$;

$\bar{Q}=$ vazão média da linha lateral, em $1 / \mathrm{m}$;

$\overline{\mathrm{T}}=$ temperatura média da àgua, em ${ }^{\mathrm{O}} \mathrm{C}$. 
Quadro 34 - Resultados gerais obtidos no Teste no 03 de Uniformida de de Vazão, referentes ao gotejador IRTEC-2, quando submetido a uma pressão constante de $10,33 \mathrm{~m}$ de coluna d'ägua.

$$
\bar{q}
$$

4,65

17,48

25,32

Média

Variância

Desvio padrão

Variância da média

Erro padrão da média

Coeficiente de Variação
0,55

0,18

0,42

0,74

0,43

0,64

0,01

0,004

0,008

0,10

0,06

0,09
Intervalo de confiança* $(1-\alpha=0,95)$
$17,36-17,60$

$25,14-25,50$
$\mathrm{T}$

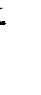

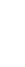


Quadro 35 - Resultados gerais obtidos no Teste no 01 de Unifomida de de Vazão, referentes ao gotejador DANTAS, quando submetido a uma pressão constante de $10,33 \mathrm{~m}$ de coluna d'água.

\begin{tabular}{|c|c|c|c|}
\hline PARÂMETROS ESTATISTICOS & $\bar{q}$ & $\bar{Q}$ & $\bar{T}$ \\
\hline Média & 4,21 & 16,95 & 20,72 \\
\hline Variância & 0,10 & 1,57 & 0,39 \\
\hline Desvio padrão & 0,31 & 1,25 & 0,63 \\
\hline Variância da média " & 0,003 & 0,05 & 0,01 \\
\hline Erro padrão da média & 0,06 & 0,23 & 0,11 \\
\hline $\begin{array}{l}\text { Intervalo de confianca* } \\
\quad(1-\alpha=0,95)\end{array}$ & $4,10-4,32$ & $16,49-17,41$ & $20,49-20,95$ \\
\hline Coeficiente de Variação & $7,35 \%$ & $7,38^{\circ}$ & $3,02 \%$ \\
\hline
\end{tabular}

sendo: $\bar{q}=$ vazão média do gotejador, em $1 / \mathrm{h}$;

$\bar{Q}$ = vazão mëdia da linha lateral, em $1 / \mathrm{m}$;

$\overline{\mathrm{T}}=$ temperatura média da ägua, em ${ }^{\mathrm{O}} \mathrm{C}$. 
Quadro 36 - Resultados gerais obtidos no Teste no 02 de Uniformida de de Vazão, referentes ao gotejador DANTAS, quando submetido a uma pressão constante de $10,33 \mathrm{~m}$ de coluna d 'água.

Média

$$
3,85
$$

17,56

22,35

Variância

Desvio padrão

0,02

0,20

0,23

0,14

0,44

0,48

Variância da média

Erro padrão da média

0,0007

0,007

0,008

0,026

0,081

0,087

Intervalo de confiança* $(1-\alpha=0,95)$

$3,80-3,90 \quad 17,40-17,72 \quad 22,18-22,52$

Coeficiente de Variação

$3,76^{\circ}$

$2,54 \%$

$2,13 \%$

sendo: $\bar{q}=$ vazão média do gotejador, em $1 / \mathrm{h}$;

$\bar{Q}=$ vazão média da linha lateral, em $1 / \mathrm{m}$;

$\mathrm{T}=$ temperatura média da ägua, em ${ }^{\mathrm{O}} \mathrm{C}$. 
Quadro 37 - Resultados gerais obtidos no Teste no 03 de Uniformida de de Vazão, referentes ao gotejador DANTAS, quando submetido a una pressão constante de $10,33 \mathrm{~m}$ de coluna d'água.

\begin{tabular}{|c|c|c|c|}
\hline PARAMMTROS ESTATISTICOS & $\bar{q}$ & $\bar{Q}$ & $\mathrm{~T}$ \\
\hline Média & 3,85 & 16,18 & 21,90 \\
\hline Variância & 0,01 & 2,64 & 0,09 \\
\hline Desvio padrão & 0,11 & $.1,63$ & 0,30 \\
\hline Variância da média & 0,0004 & 0,09 & 0,003 \\
\hline Erro padrão da média & 0,020 & 0,30 & 0,056 \\
\hline $\begin{array}{l}\text { Intervalo de confiança* } \\
\quad(1-\alpha=0,95)\end{array}$ & $3,81-3,89$ & $15,58-16,78$ & $21,79-22,01$ \\
\hline Coeficiente de Variação & $2,91 \%$ & $10,04 \%$ & $1,39 \%$ \\
\hline
\end{tabular}

sendo: $\bar{q}=$ vazão média do gotejador, em $1 / \mathrm{h}$;

$\bar{Q}=$ vazão média da 1 inha lateral, em $1 / \mathrm{m}$;

$\overline{\mathrm{T}}$ = temperatura média da água, em ${ }^{\mathrm{O}} \mathrm{C}$. 
182 .

A P E N D I C E 3

DADOS OBTIDOS NOS TESTES

PARA DETERMINAÇÃO DA EQUA

CCAO CARACTERISTICA DE DES CARGA-PRESSÃO 。 


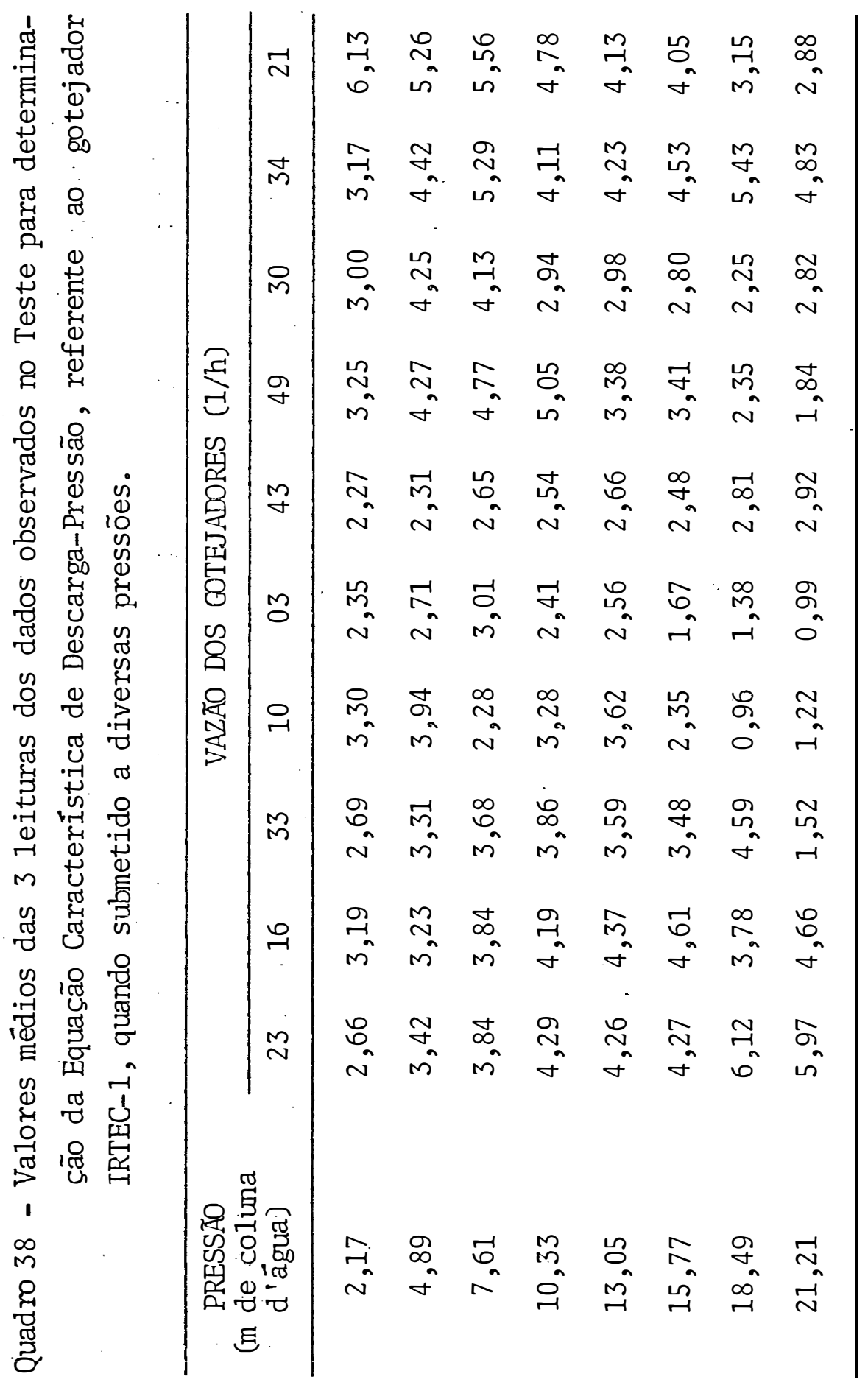




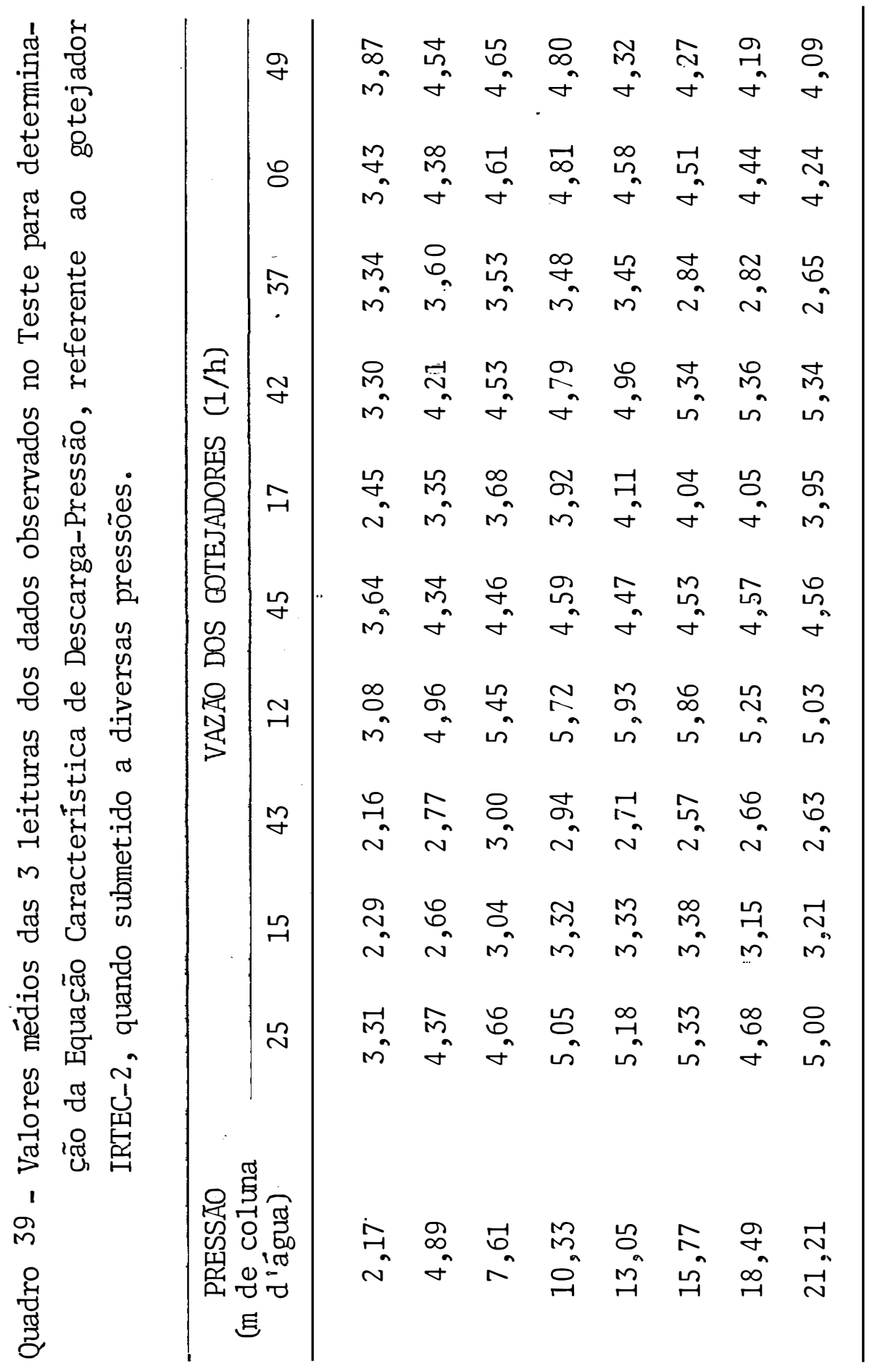




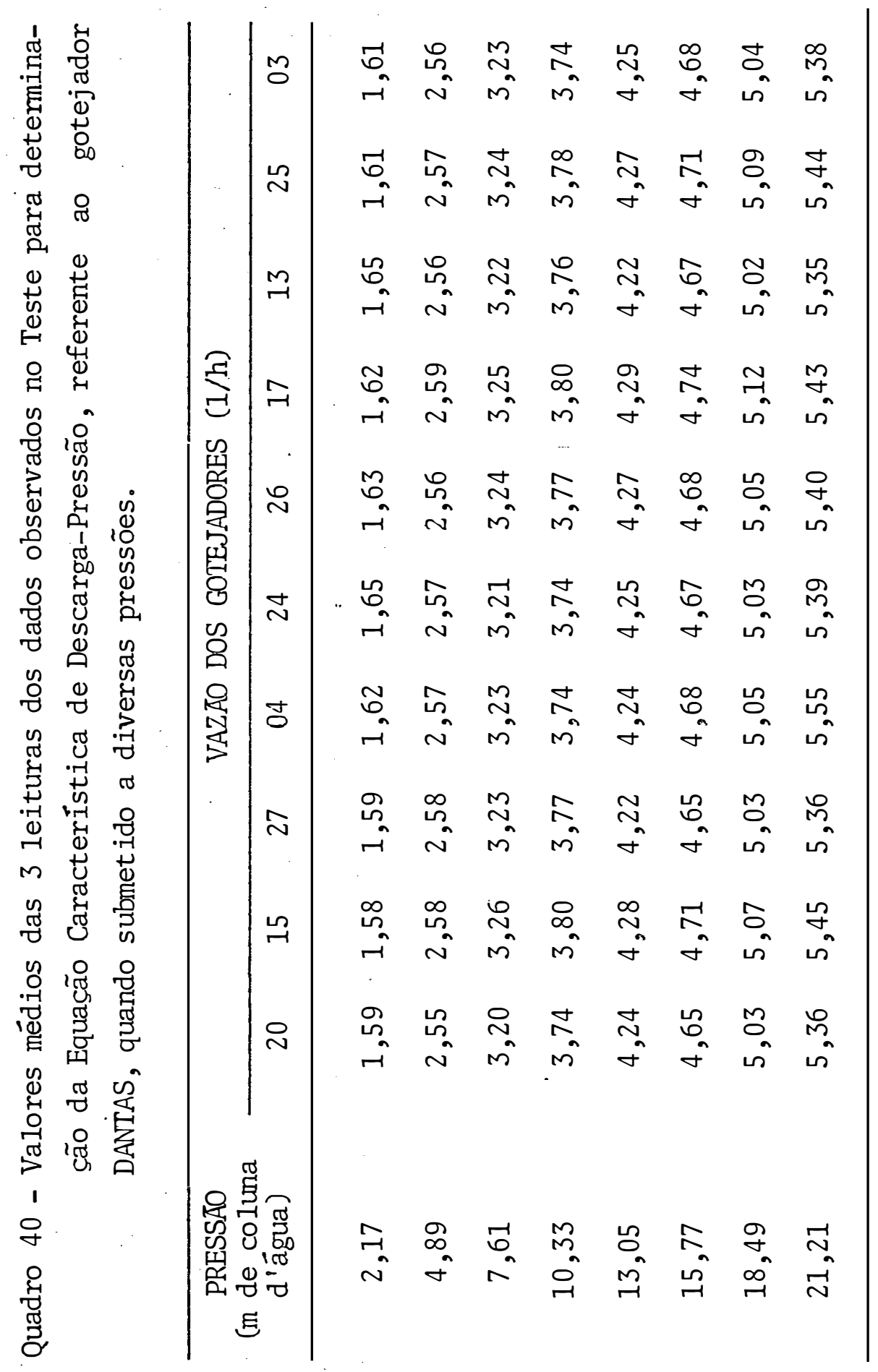




\section{$A \mathbb{P} \mathbb{N}$ I $\mathrm{IE}$}

RESULTADOS DA ANĀLISE DE REGRESSÃO PARA AS EQUAÇOES GEO MÉTRICA E POLINOMIAL. 
Quadro 41 - Análise de regressão da equação geométrica deterninada através dos dados relativos ao efeito da pressão sobre a vazão do gotejador IRTEC-1.

\begin{tabular}{lcccc}
\hline Causas de Variação & G.L. & S.Q. & Q.M. & F \\
\hline Regressão & 1 & 6,4099 & 6,4099 & $8,41^{* *}$ \\
Desvios de regressão & 6 & 0,6784 & 0,1131 & $0,15^{\mathrm{ns}}$ \\
\hline (Pressões) & $(7)$ & $(7,0883)$ & & \\
Gotejadores & 9 & 52,6360 & & \\
Resíduo & 63 & 48,0242 & 0,7623 & \\
\hline Total & 79 & 107,7485 & & \\
\hline
\end{tabular}

** = Significativo ao nível de $1 \%$ de probabilidade;

ns $\fallingdotseq$ Não significativo. 
Quadro 42 - Aná1ise de regressão da equação geométrica determinada através dos dados relativos ao efeito da pressão sobre a vazão do gotejador IRTEC-2.

\begin{tabular}{lrrrr}
\hline Causas de Variação & "G. L. & S.Q. & Q.M. & \multicolumn{1}{c}{ F } \\
\hline Regressão & 1 & 11,1153 & 11,1153 & $87,38^{* *}$ \\
Desvios dèRegressão & 6 & 0,4511 & 0,0752 & $0,59^{\text {ns }}$ \\
\hline (Pressões) & $(7)$ & $(11,5664)$ & & \\
Gotejadores & 9 & 49,0149 & & \\
Resi̊duo & 63 & 8,0140 & 0,1272 & \\
\hline Tota1 & 79 & 68,5953 & & \\
\hline
\end{tabular}

** = Significativo ao nivel de $1^{\circ}$ de probabilidade. ns = Não significativo. 
Quadro 43 - Anälise de regressão da equação geomëtrica deteminada atravês dos dados relativos ao efeito da pressão sobre a vazão do gotejador DANTAS.

\begin{tabular}{lcrrr}
\hline Causas de Variação & G.L. & \multicolumn{1}{c}{ S.Q. } & Q.M. & \multicolumn{1}{c}{ F } \\
\hline Regressão & 1 & 117,6163 & 117,6163 & $178206,51^{* *}$ \\
Desvios de Regressão & 6 & 0,0095 & 0,0016 & $2,42^{\text {ns }}$ \\
\hline (Pressões) & $(7)$ & $(117,6258)$ & & \\
Gotejadores & 9 & 0,0272 & & \\
Resíduo & 63 & 0,0415 & 0,00066 & \\
\hline Tota1 & 79 & 117,6945 & & \\
\hline
\end{tabular}

** = Significativo ao nível de $1^{\circ}$ de probabilidade;

$\mathrm{ns}=$ Não significativo. 
Quadro 44 - Análise da variância e regressão polinomial dos dados relativos ao efeito da pressão sobre a vazão do goteja dor IR'TEC-1.

\begin{tabular}{lcccc}
\hline Causas de Variação & G.L. & S.Q. & Q.M. & F \\
\hline Regressão Linear & 1 & 1,859 & 1,859 & $2,44^{\mathrm{ns}}$ \\
Regressão Quadrātica & 1 & 4,070 & 4,070 & $5,34^{*}$ \\
Desvios de Regressão & 5 & 1,159 & 0,232 & $0,30^{\mathrm{ns}}$ \\
\hline (Pressões) (P) & $(7)$ & $(7,088)$ & & \\
Gotejadores (G) & 9 & 52,640 & & \\
Resíduo (G X P) & 63 & 48,020 & 0,762 & \\
\hline Total & 79 & 107,748 & & \\
\hline
\end{tabular}

* = Significativo ao nível de 5\% de probabilidade; ns $=$ Não significativo. 
Quadro 45 - Análise da variância e regressão polinomial dos dados relativos ao efeito da pressão sobre a vazão do gotejador IR'TEC-2. .

\begin{tabular}{lcccc}
\hline Causas de Variação & G.L. & S.Q. & Q.M. & F \\
\hline Regressão Linear & 1 & 3,960 & 3,960 & $31,18^{* *}$ \\
Regressão Quadrática & 1 & 6,413 & 6,413 & $50,50^{* *}$ \\
Regressão Cübica & 1 & 1,047 & 1,047 & $8,24^{* *}$ \\
Desvios de regressão & 4 & 0,146 & 0,0365 & $0,29^{\mathrm{nS}}$ \\
\hline (Pressões) (P) & $(7)$ & $(11,566)$ & & \\
Gotejadores (G) & 9 & 49,015 & & \\
Residuo (G $\times$ P) & 63 & 8,014 & 0,127 & \\
\hline Tota1 & 79 & 68,595 & & \\
\hline
\end{tabular}

** = Significativo ao nível de $1 \%$ de probabilidade;

ns = Não significativo. 
Quadro 46 - Análise da variância e regressão polinomia1 dos dados relativos ao efeito da pressão sobre a vazão do gotejador DANTAS.

\begin{tabular}{lcrrr}
\hline Causas de Variação & G.L. & S.Q. & Q.M. & \multicolumn{1}{c}{ F } \\
\hline Regressão Linear & 1 & 114,402 & 114,4020 & $163431,42^{* *}$ \\
Regressão Quadrätica & 1 & 2,938 & 2,9380 & $4197,14^{* *}$ \\
Regressão Cúbica & 1 & 0,239 & 0,2390 & $341,43^{* *}$ \\
Regressão de 49 grau & 1 & 0,036 & 0,0360 & $51,43^{* *}$ \\
Regressão de 5! grau & 1 & 0,010 & 0,0100 & $14,29^{* *}$ \\
Desvios de regressão & 2 & 0,001 & 0,0005 & $0,71^{\mathrm{ns}}$ \\
\hline (Pressões) (P) & $(7)$ & $(117,626)$ & & \\
Gotejadores (G) & 9 & 0,027 & & \\
Residuo (G x P) & 63 & 0,042 & 0,0007 & \\
\hline Total & 79 & 117,695 & & \\
\hline
\end{tabular}

** = Significativo ao nivel de $1^{\circ}$ de probabilidade;

ns = Não significativo. 